\title{
A revised sedimentary and biostratigraphical architecture for the Type Llandovery area, Central Wales
}

\author{
JEREMY R. DAVIES*†, RICHARD A. WATERS $\ddagger$, STEWART G. MOLYNEUX $\S$, \\ MARK WILLIAMS $\uparrow$, JAN A. ZALASIEWICZ \\ \& JACQUES VERNIERS\# \\ *British Geological Survey, c/o Institute of Geography and Earth Sciences, Aberystwyth University, Aberystwyth, \\ SY23 3DB, UK \\ $\ddagger$ Department of Geology, National Museum of Wales, Cathays Park, Cardiff, CF10 3NP, UK \\ §British Geological Survey, Keyworth, Nottingham, NG12 5GG, UK \\ TDepartment of Geology, University of Leicester, University Road, Leicester, LE1 7RH, UK \\ |UMR 8217 du CNRS: Géosystèmes, Université Lille 1, bâtiment SN5, Avenue Paul Langevin, 59655 Villeneuve \\ d'Ascq cedex, France \\ \#Ghent University, WE13 Palaeontology, Krijgslaan 281 S8, BE-9000 Ghent, Belgium
}

(Received 5 September 2011; accepted 24 April 2012; first published online 29 October 2012)

\begin{abstract}
The global standard for the Llandovery Series (early Silurian) in central Wales is re-assessed in the light of detailed geological surveying, biostratigraphical sampling and a rigorous examination of published datasets. A new sedimentary and biostratigraphical architecture is presented. Key graptolite, brachiopod, acritarch and, for the first time, chitinozoan assemblages are critically assessed. Upper Hirnantian to Aeronian strata record events that followed the Late Ordovician glacial maximum and comprise a series of progradational sequences bounded by flooding surfaces, but inferred still to be glacioeustatic in origin. Significant faunal renewals associated with many of the flooding levels underpin their potential for international recognition. Compound non-sequences are a feature of proximal parts of the system where erosion associated with fault footwall uplift was an important process. Extensive slump sheets contribute to further stratal loss and displacement in distal facies. A re-assessment of the Aeronian Stage GSSP reveals shortcomings with the biostratigraphical criteria used in its selection. Telychian portions of the succession display the disrupting effects of intraWenlock synsedimentary sliding; hence the relevance of key published fossil assemblages and the criteria used to erect the stage GSSP are undermined. However, the Llandovery area remains one of the best studied early Silurian successions in the world. This, together with regional considerations, supports the retention of the series standard in mid Wales where the contiguous deep-water basinal succession affords internationally cited exposure of richly graptolitic facies for the whole series and, significantly, for the post-sedgwickii Biozone interval.
\end{abstract}

Keywords: Llandovery, Aeronian, Telychian, sedimentary architecture, sequence stratigraphy, biostratigraphy, microfossils.

\section{Introduction and setting}

The outcrop of lower Silurian rocks east of the town of Llandovery in south central Wales constitutes the type area, or 'global standard', for the Llandovery Series (Cocks, 1989) (Figs 1, 2). Detailed new geological mapping, allied to biostratigraphical, sedimentological and sequence analysis, underpins a new stratigraphical synthesis and thoroughly revised sedimentary architecture for this type succession (Fig. 3).

Deposited in mid southern palaeo-latitudes on the micro-plate of Eastern Avalonia, the Llandovery area succession comprises a spectrum of variably bioturbated sandstones and mudstones. Facies and fauna are consistent with accumulation on a periodically emergent shelf or ramp that bordered a region of enhanced subsidence and deep-water sedimentation to the northwest: the Lower Palaeozoic Welsh Basin

$\dagger$ †uthor for correspondence: jrdav@bgs.ac.uk
(Davies et al. 1997). The late Hirnantian to Llandovery succession in Wales, as elsewhere, records deposition following a major episode of South Polar ice sheet expansion on the super-continent of Gondwana (e.g. Page et al. 2007). The major SW-NE-trending, basinbounding faults that traverse the Llandovery area are components of the long-lived Welsh Borderland Fault System and its integral Tywi and Pontesford lineaments (Fig. 1) (Woodcock \& Gibbons, 1988). Movements on these structures influenced Silurian sedimentation in the region and caused locally significant synsedimentary deformation. Strata in the Llandovery area also display the pervasive effects of transpressive mid Devonian orogenesis, including a regional cleavage (Woodcock, Soper \& Strachan, 2007).

\section{Previous research}

Authoritative accounts of the history of research in the Llandovery area are given by Cocks et al. (1984) and 


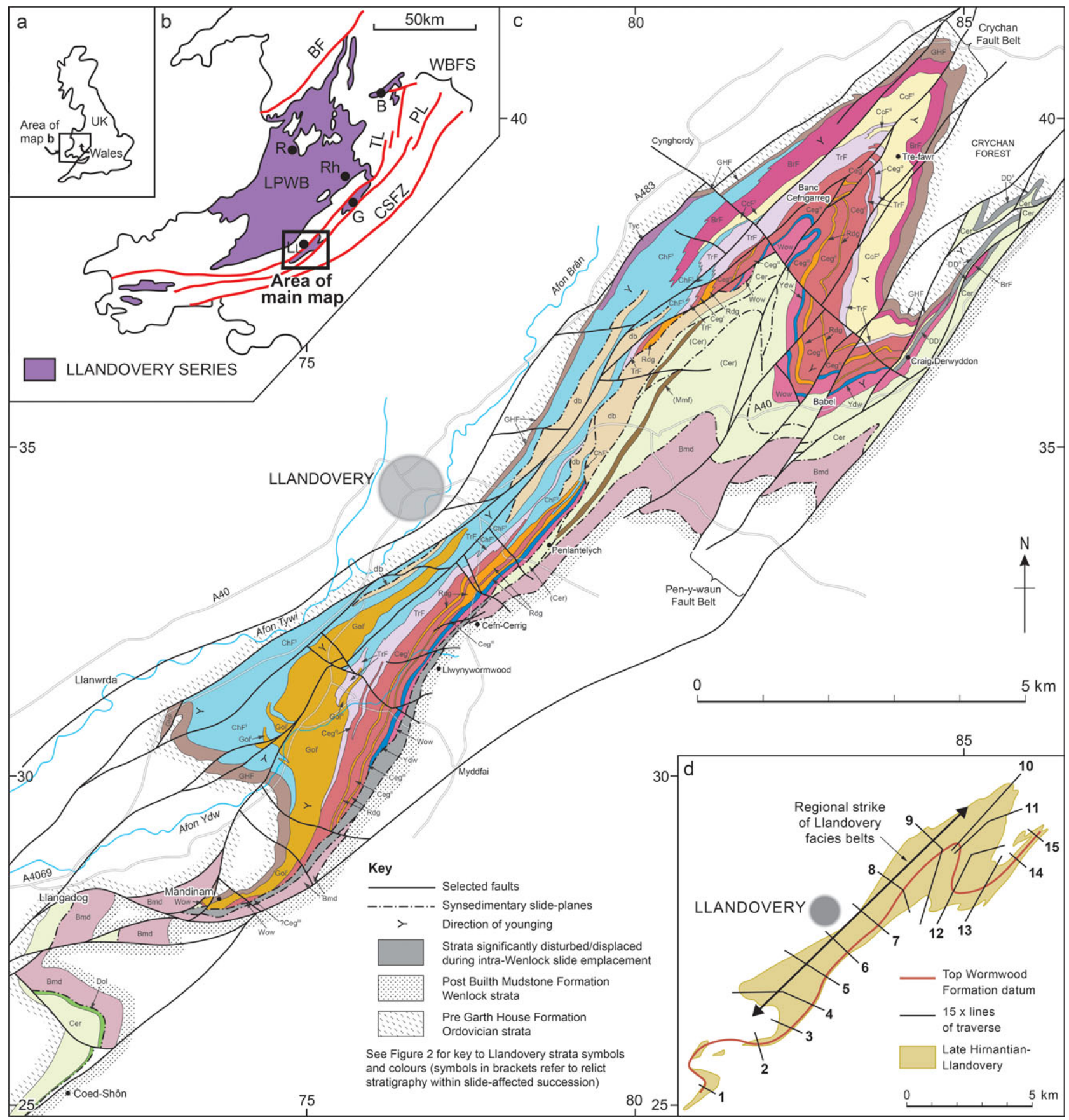

Figure 1. (Colour online) (a-c) Llandovery Series rocks in Wales and a simplified geology map of the Type Llandovery area (significantly modified after BGS, 2005a,b, 2009); UK National Grid co-ordinates refer to $100 \mathrm{~km}$ square SN. Abbreviations: B - Banwy River; BF - Bala Fault; CSFZ - Church Stretton Fault Zone; G - Garth; LL- Llandovery; LPWB - Lower Palaeozoic Welsh Basin; PL Pontesford Lineament; R - Rheidol Gorge; Rh - Rhayader; TL - Tywi Lineament; WBFS - Welsh Borderland Fault System; see Figure 2 for key to main map symbols. (d) Location of traverse lines used in the construction of Figure 3. Geological data BGS (C)NERC 2012. Contains Ordnance Survey data (C) Crown Copyright \& database rights 2012. Licence No. 100021290.

Bassett (1991). The seminal studies of Jones (1921, $1925,1949)$ and Williams $(1951,1953)$ established the succession as the UK standard for lower Silurian rocks. The co-occurrence of graptolite and benthic fossil assemblages allowed the lithostratigraphical subdivisions (A, B and C) of Jones (1925) (Fig. 2) also to be defined in biostratigraphical terms, and this underpinned adoption of the Lower (A), Middle (B) and Upper (C) Llandovery stages as the standard chronostratigraphical nomenclature for the UK.
Following Williams's (1951) and Zeigler's (1965, 1966; Zeigler, Cocks \& Bambach, 1968) work on brachiopod assemblages and lineages, Jones's (1925) finer scale subdivisions also became widely used as de facto chronozones (e.g. Zeigler, Cocks \& McKerrow, 1968; Cocks et al. 1971).

The need for international correlation and Global Boundary Stratotype Sections and Points (GSSPs) (see review by Holland, 1989) initiated a phase of further detailed study and led ultimately to the 


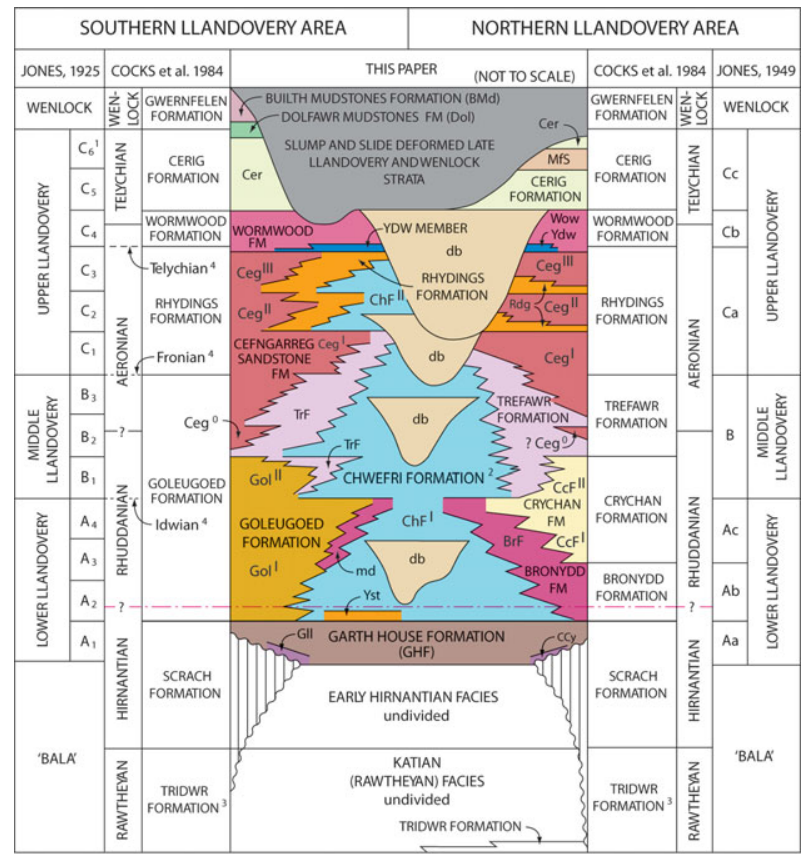

[11] Unconformity linked to late Ordovician - Putative Ashgill / L

Figure 2. (Colour online) Old and new stratigraphical nomenclature for the Type Llandovery area (modified after Schofield et al. 2009b). Abbreviations and notes: CCy - Cwm Clyd Sandstone Formation; db - slump/slide-disturbed strata; Gll Glasallt-fawr Sandstone Formation; md - sandy mudstone in Goleugoed Formation; Yst - Ystradwalter Member; 1 - now recognized as the Mwmffri Sandstone Member (MfS); 2 broadly equivalent to the Coldbrook Formation of Cocks et al. (1984); 3 - now recognized as an older Katian (Rawtheyan) unit (see Schofield et al. 2004); 4 - abandoned former stage bases of Cocks, Toghill \& Zeigler (1970) (N.B. base Rhuddanian Stage was not formally identified in the Llandovery area and the precise position of base Aeronian is uncertain in the southern Llandovery area).

landmark publication of Cocks et al. (1984) that successfully established the Llandovery succession as the international series standard (Fig. 2). The constituent Rhuddanian, Aeronian and Telychian stages all take their names from sections near Llandovery and, though the adoption of Dob's Linn in Scotland as the basal Silurian stratotype made this the de facto base of the Rhuddanian Stage, both the other stages have their GSSPs in the type area (see Section 5). Cocks and his co-workers remapped the area, revised the graptolite and brachiopod biostratigraphy and, for the first time, undertook a detailed study of acritarch assemblages (Hill \& Dorning, 1984). This work established a new lithostratigraphical and architectural model that emphasized the intact nature of the succession and continues to underpin the current international usage of the term Llandovery and its constituent stages (e.g. Cocks, 1989; Holland \& Bassett, 2002; Cocks, Fortey \& Rushton, 2010). However, it should be noted that Temple (1988), although a co-author, dissented from the conclusions of Cocks et al. (1984, p. 164), questioning the criteria used and the requirement to erect and define the current Aeronian and Telychian stages and their GSSPs.

Over the last 25 years, the British Geological Survey (BGS) and its collaborators have undertaken detailed mapping and interpretation of the deep-water Llandovery facies of the Lower Palaeozoic Welsh Basin in central Wales. This has contributed to a detailed understanding of basinal depositional events and processes (e.g. Woodcock et al. 1996; Davies et al. 1997; Schofield et al. 2009a). In the last decade this work has been extended into the shelf successions of the Garth and Llandovery areas (Fig. 1), where the establishment of an event stratigraphy common to both the basin and shelf successions has been a central aim. New surveying has enabled significant revision to the stratigraphy and structure of Cocks et al. (1984), as summarized in texts (Schofield et al. 2004, 2009b; Barclay et al. 2005) that accompany the recently published maps (BGS, 2005a,b, 2008). However, presented here are important additional modifications that stem from more recent findings.

Many of the most important sections in the Llandovery area have been documented by Cocks (1971), Siveter, Owens \& Thomas (1989) and, as part of the UK's Geological Conservation Review, by Aldridge (2000). Upgraded descriptions of some of the key localities investigated as part of the current study are provided in field guides by Davies et al. $(2010,2011)$. Details of some of the key new and previously cited fossil assemblages from the Llandovery area are given in Appendix 1, but form only a fraction of the extensive published and unpublished database. Fossil localities are cited in the text in the form [1a], [1b], etc., where the number refers to a traverse line (column) on Figure 11, and the letter to the locality on that line.

\section{New architectural model}

The new architectural model is based on 15 lines of traverse (Fig. 3) projected on to a common datum the top of the Aeronian Wormwood Formation - and is constructed in a way that allows comparison with the architectures previously erected by Jones (1949, fig. 3) and Cocks et al. (1984, fig. 118). It provides the framework for a radical re-assessment of the Llandovery succession, whilst demonstrating the continuing international relevance of the area's mixed planktonic and benthic fossil assemblages.

\section{3.a. Lithostratigraphy}

The Llandovery succession comprises up to $2.2 \mathrm{~km}$ of shelf/ramp strata, deposited predominantly below the reach of frequent wave reworking. It can be divided into two distinct parts: a lithologically complex Rhuddanian to Aeronian lower part that includes bioturbated sandstones, muddy sandstones, sandy mudstones and silty mudstones; and an upper part comprising up to $740 \mathrm{~m}$ of mudstone-dominated Telychian strata. 


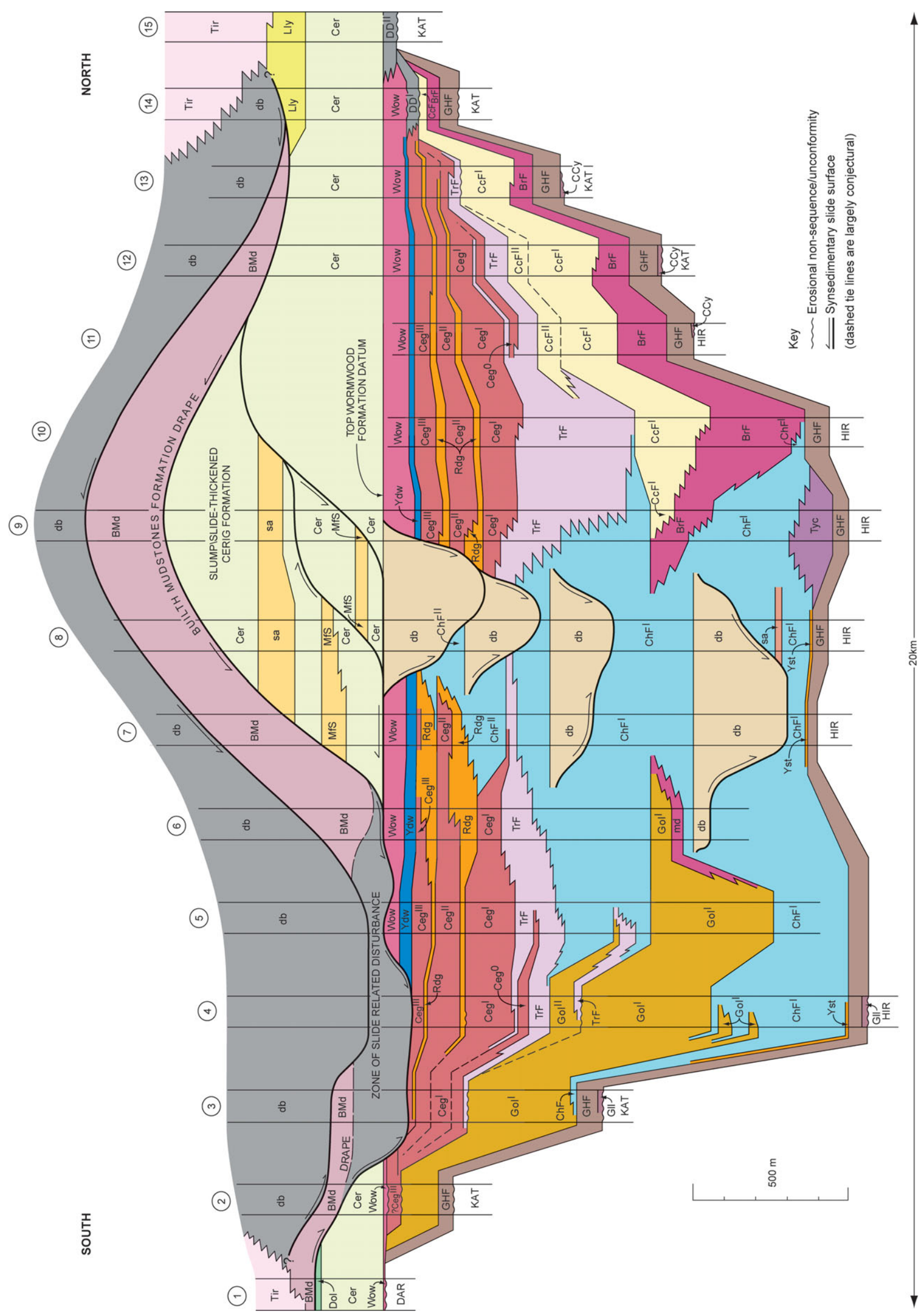

Figure 3. (Colour online) New architectural model for the Type Llandovery succession; see Figure 2 for key and Figure $1 \mathrm{~d}$ for location of lines of traverse. The abbreviations DAR, HIR and KAT at the bases of the columns refer, respectively, to the Darriwilian (Llanvirn), Katian (Rawtheyan) and Hirnantian ages of the underlying Ordovician strata. Other abbreviations: DD - Derwyddon Formation; Lly - Llangammarch Formation; sa-sandstone-rich units in ChF and Cer; Tir - Tirabad Formation; Tyc - Tycwtta Mudstones Formation. 
Cross-cutting relationships persuaded Jones (1925, 1949) that a number of erosional diastems were present within the succession. This underpinned his erection of a three-fold stratigraphical scheme (units A, B and C) and recognition of up to 13 subdivisions (A1-4; B13; C1-6) (Fig. 2). Cocks et al. (1984) presented much broader groupings of strata and did not differentiate many of the smaller scale units recognized by Jones (Fig. 2). They argued, in support of their successful bid for it to be recognized as the international series stratotype, that throughout much of its outcrop the succession was both stratigraphically intact and largely unaffected by faulting. However, the current work broadly vindicates Jones' (1925) level of subdivision and, whilst there are important differences in detail, has confirmed that erosional non-sequences are a feature of the succession in some areas. Significantly, the recognition and mapping of a finer scale stratigraphy has also revealed greater structural complexity than envisaged by both Jones $(1925,1949)$ and Cocks et al. (1984; also Woodcock, 1987) (Fig. 1).

A feature of the work of Jones $(1925,1949)$ and Cocks et al. (1984) was the erection of different stratigraphical schemes for the southern and northern parts of the area (Fig. 2). This reflects the presence of a distinctive, intervening, central facies belt. Jones thought the absence of key units in this region was the result of unconformity, but Cocks et al. (1984) correctly recognized the importance of lateral facies changes between more proximal, sand-prone units present in the north and south, and a more distal, mud-prone tract in the centre. An aim of the current work has been to rationalize the nomenclature used throughout the Llandovery area. In doing this, every attempt has been made to use the existing, widely cited, Cocks et al. (1984) nomenclature; only where necessary have new names been introduced.

\section{3.a.1. Rhuddanian and Aeronian strata}

The complex lateral and vertical facies changes that characterize the Rhuddanian to Aeronian stratigraphy are shown in Figures 1-3 and in sedimentary logs (Fig. 4). Burrow-mottled Chwefri Formation mudstones pass northwards into sandy mudstones of the Bronydd and younger Trefawr formations. Both these divisions in turn pass into muddy, locally pebbly, strongly burrow-mottled Crychan Formation sandstones in which separate units $\left(\mathrm{CcF}^{\mathrm{I}}\right.$ and $\left.\mathrm{CcF}^{\mathrm{II}}\right)$ have been distinguished locally. In the south, the Chwefri Formation passes into the Goleugoed Formation that has been redefined, permitting recognition of the Trefawr Formation. The name Goleugoed Formation is now restricted to a facies that comprises muddy sandstones with distinctive, partially bioturbated, sandstone beds. The bulk of its outcrop comprises a thick older portion $\left(\mathrm{Gol}^{\mathrm{I}}\right)$, but a laterally restricted younger unit $\left(\mathrm{Gol}^{\mathrm{II}}\right)$ has been mapped in the Ydw valley area. Upper parts of the Trefawr Formation pass into a widespread lower unit of the muddy and mottled Cefngarreg
Sandstone Formation (Ceg ${ }^{\mathrm{I}}$ ) (Figs 4B, 5a); together these units divide the Chwefri Formation into a lower $\left(\mathrm{ChF}^{\mathrm{I}}\right)$ and an upper $\left(\mathrm{ChF}^{\mathrm{II}}\right)$ part (Fig. 4A). An earlier leaf of Cefngarreg Sandstone ( $\left.\mathrm{Ceg}{ }^{0}\right)$ mapped in the south Llandovery area is correlated with the sandstone unit in the north that hosts the Aeronian GSSP in the Trefawr track section (Davies et al. 2011) (Fig. 4C). A key change to the Cocks et al. (1984) lithostratigraphy is the recognition of separate sandstone and mudstone facies within their Rhydings Formation. The latter name is retained for sandy mudstone facies whereas sandstone-dominated parts are now recognized as younger units of Cefngarreg Sandstone Formation (Ceg II and Ceg ${ }^{\text {III }}$ ) (Fig. 2). In the north, a younger sandstone-dominated unit, now recognized as the upper Aeronian to lowest Telychian Wormwood Formation, was initially included in the Cefngarreg Sandstone (BGS, 2005b; Barclay et al. 2005). In a significant modification to its usage, the locally fossiliferous Wormwood Formation has been extended downwards to include the newly erected, mudstone-dominated $\mathrm{Ydw}$ Member at its base (Fig. 4E). Note of this change is important since the equivalent strata were included by Cocks et al. (1984) in their Rhydings Formation and by Jones (1925) in his $\mathrm{C}_{3}$ division, and are now shown to host key fossil assemblages (see Section 4.a). In the northeast, the Wormwood Formation and upper levels of the underlying Cefngarreg Sandstone Formation pass into separate units of pentameridrich Derwyddon Formation sandstone (DD ${ }^{\mathrm{I}}$, DD ${ }^{\mathrm{II}}$ ) (Fig. 4F).

\section{3.a.2. Telychian strata}

Blanketing the varied lower to mid Llandovery strata are the green, burrow-mottled mudstones that comprise the Telychian Cerig Formation. However, this study has shown that the disrupting effects of slumping and Wenlock slide emplacement are widespread in this portion of the stratigraphy such that the Cerig Formation type section (Fig. 4D) has had to be relocated. Davies et al. (2010) have proposed track sections in Crychan Forest that expose the conformable and dated base of the formation [SN 8546 3846] as the new type locality [15c] for this distinctive and widely mapped late Llandovery division.

\section{3.a.3. Pre- and post-Llandovery strata}

Changes by Davies et al. (2009) to the interpretation of Hirnantian facies present below the Type Llandovery succession include abandonment of the term and concept of Cocks et al.'s (1984) 'Scrach Formation'. In the revised model, the transgressive Garth House Formation oversteps earlier regressive Hirnantian facies preserved to the west of the Crychan Fault Belt, and rests unconformably on Katian (Rawtheyan) strata to the east. Further south, upper parts of the Llandovery succession overstep onto rocks of Darriwilian 

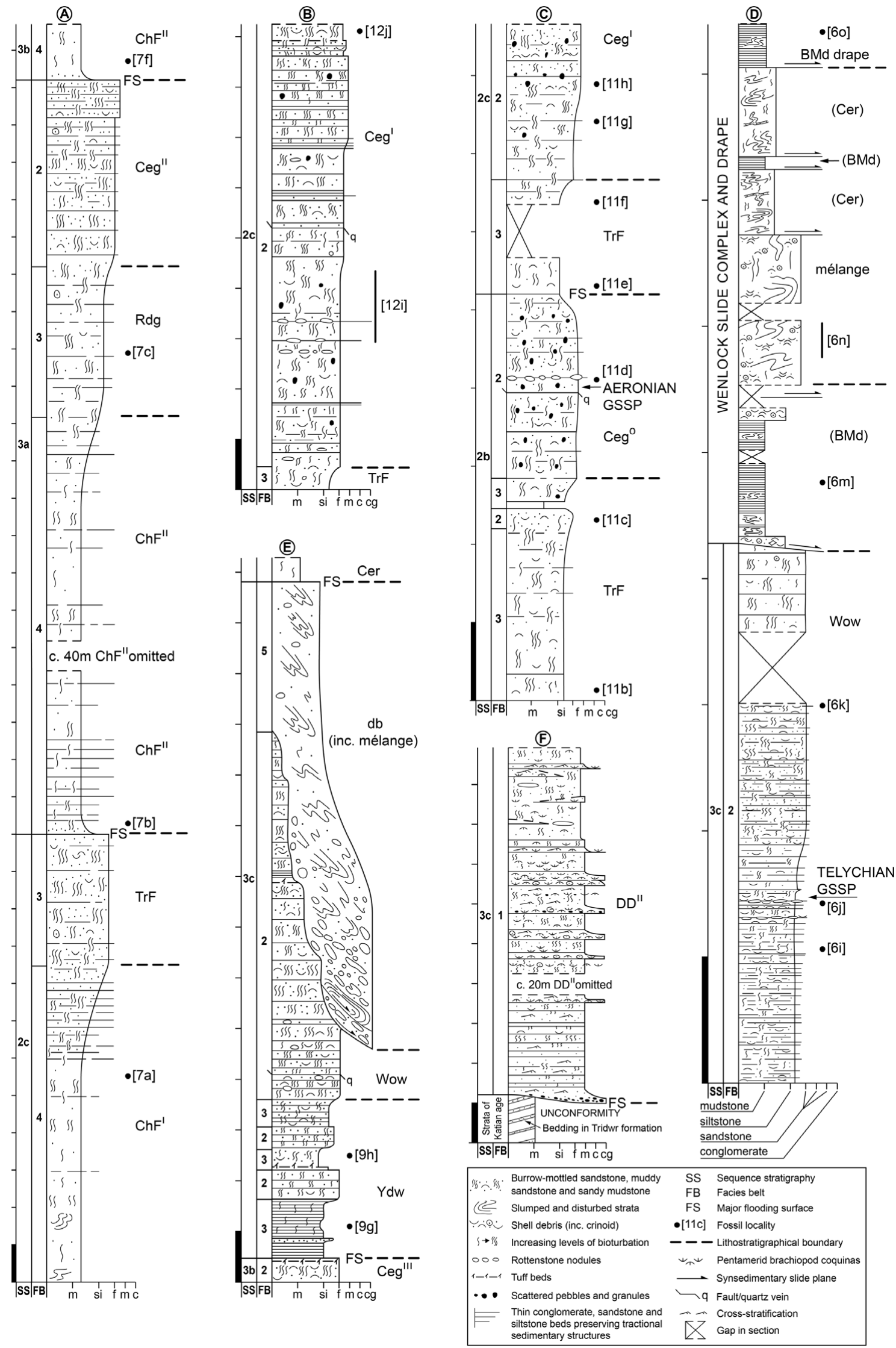

Figure 4. Sedimentary logs of selected sections in the Type Llandovery area: A - Troedrhiwfelen stream (Traverse 7); B - Cwm-coedoeron track (Traverse 12); C - Trefawr track (Traverse 11); D - Cefn Cerig (Cerrig) quarry and cuttings (Traverse 6) (includes former type section of Cerig Formation); E - Glyn-moch track (Traverse 9); and F - Fire Tower Hill tracks (Traverse 15). Logs B-E adapted from Davies et al. (2010, 2011); SS numbers refer to Figure 8; FB numbers refer to Figures 6-8. For details of fossil localities [in square brackets] and map grid references refer to Figure 11 and Appendix 1. See Figures 1-3 for key to lithostratigraphical symbols. Vertical scale bars for $\mathrm{A}-\mathrm{E}=10 \mathrm{~m}$, for $\mathrm{F}=1 \mathrm{~m}$. 

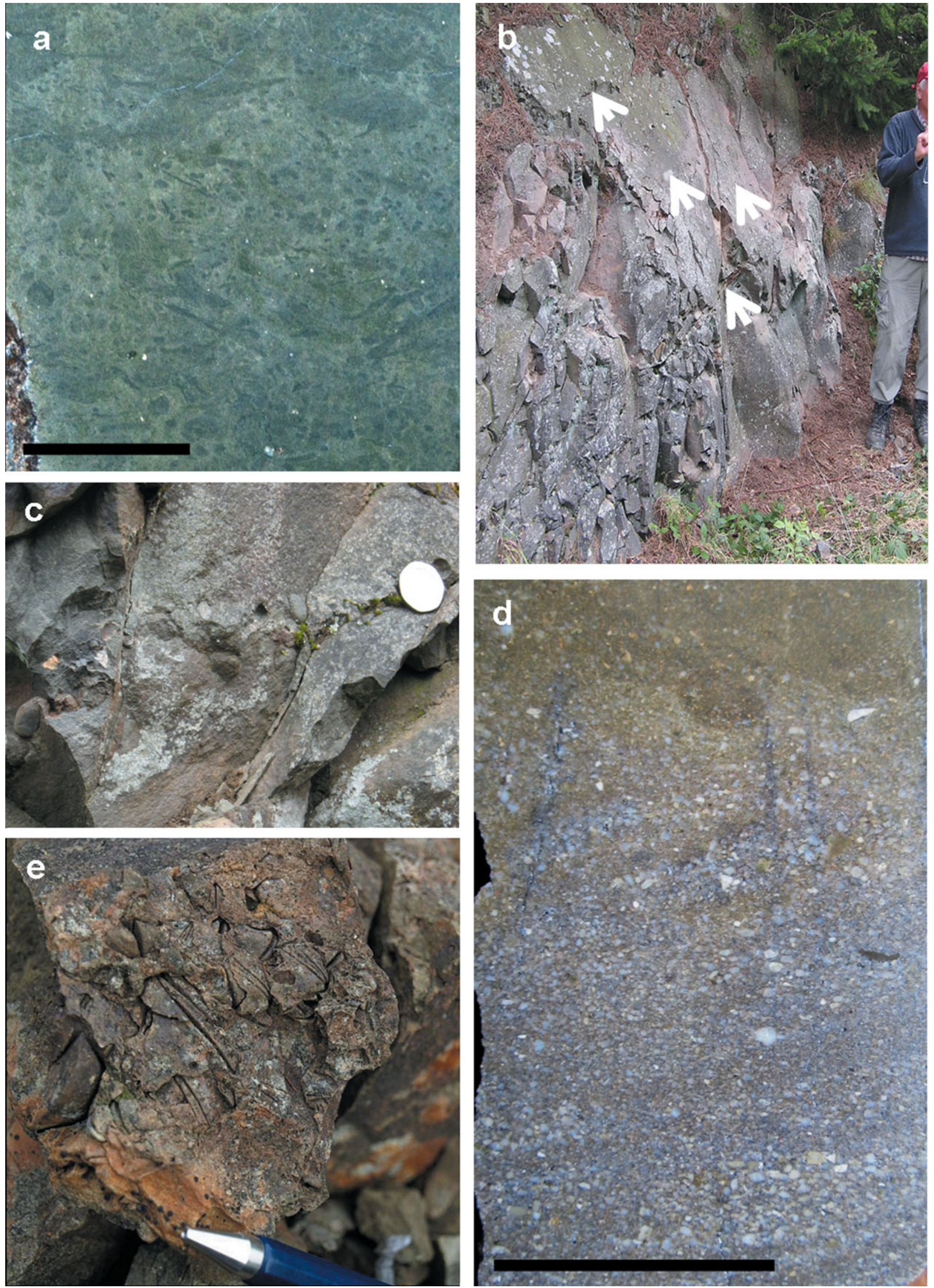

Figure 5. (Colour online) Type Llandovery area lithologies: (a) Intensely bioturbated and burrow-mottled muddy sandstone, Cefngarreg Sandstone Formation ( $\mathrm{Ceg}^{\mathrm{I}}$ ), Cwm-coed-oeron [SN 8363 3896] (scale is $5 \mathrm{~cm}$ ); (b) field appearance of (a); arrows point to impersistent, partially bioturbated conglomerate lags and sandstone beds; (c) close-up of burrowed conglomerate lag in (b) (coin diameter is $27 \mathrm{~mm}$ ); (d) cross-stratified granule conglomerate, bioturbated in upper part, Derwyddon Formation (DD ${ }^{\mathrm{I}}$ ), Craig Derwyddon [SN 8429 3647] (scale is $5 \mathrm{~cm}$ ); (e) coquina of Pentamerus oblongus brachiopod valves in Derwyddon Formation (DD ${ }^{\mathrm{II}}$ ) sandstone, Fire Tower Hill [SN 8538 3844] (pen diameter is $7 \mathrm{~mm}$ ). 
(Llanvirn) age. Subdivision and nomenclature for the local Wenlock succession follows that erected for the Builth Wells area (Zalasiewicz \& Williams, 1999; Schofield et al. 2004), the Builth Mudstones Formation being the equivalent of Cocks et al.'s (1984) Gwernfelen Formation. However, the impacts of regional-scale slump and slide emplacement (e.g. Fig. 4D) dominate much of the Wenlock stratigraphy in the Llandovery area (Figs 3,8).

\section{3.b. Facies models and benthic communities}

Pre-Cerig Formation facies of the Type Llandovery succession have been interpreted in the context of a generic clinoform model that comprises five broad facies belts: (1) topset; (2) upper foreset; (3) lower foreset; (4) bottomset; and (5) slump belt. The palinspastic relationships and intergradational sedimentary characteristics of these five belts are summarized in Figures 6 and 7; Figures 4 and 8 also make clear their close correspondence to the area's lithostratigraphical divisions. Lithological differences between upper and lower foreset facies form the basis for the separate recognition of the Crychan and Bronydd formations in the northern Llandovery region. Complex intertonguing of comparable facies prevents straightforward subdivision of the correlative Goleugoed Formation in the south. The latter, accordingly, can be viewed as an undivided succession of Rhuddanian foreset facies (Figs 6, 8).

A detailed sedimentological analysis of the Type Llandovery succession is beyond the scope of this account. Broadly speaking, however, the various Llandovery divisions record a series of progradational events (progrades) in which mud-prone bottomset facies pass laterally and vertically upwards into more sand-prone foreset units (e.g. Fig. 4A). Systematic changes in the degree of bioturbation, quantified with reference to the bioturbation index (BI) of Taylor \& Goldring (1993), parallel these textural variations (Figs 6, 7). In thinner-bedded and weakly disrupted bottomset facies (BI 1-2), separate beds and laminae of sandstone, siltstone and mudstone survive and Chondrites and Zoophycos are the dominant trace fossils. In the thicker-bedded foreset facies the effects of bioturbation dominate. Primary sand, silt and mud layers have been thoroughly mixed together (BI 45) to produce homogeneous, strongly burrow-mottled, sandy mudstones and muddy sandstones with a diverse suite of trace fossils (Figs 5a, 7). Conglomerate lags and relict thin sandstone beds that have escaped the full effects of bioturbation preserve the only evidence of tractional processes (Fig. 5b, c). Despite variations in the levels of burrowing, the bulk of the succession records oxic deposition. Dysoxic conditions are evidenced in weakly bioturbated Chwefri Formation facies, but only in the Tycwtta Mudstones Formation, an upper slope deposit of late Hirnantian to Rhuddanian age, are anoxic facies, preserving undisrupted hemipelagic lamination, widespread (Davies et al. 1997).
The distribution of bathymetrically influenced benthic communities (Cocks, 1971; Cocks et al. 1984) also broadly reflects these facies subdivisions. The shallowest Eocoelia and Pentamerus communities are present in upper foreset facies represented by shoaling parts of the Goleugoed, Crychan and Wormwood formations, and dominate the most proximal topset successions in the south and in the type Derwyddon Formation area (Fig. 5d, e). Temple's (1987) work has shown that Borealis replaces Pentamerus in Rhuddanian 'Pentamerus community' assemblages (cf. Cocks, 1971) [e.g. 5b]. Stricklandia community assemblages are also widespread in upper foreset facies whereas more offshore Clorinda community assemblages characterize lower foreset units. Assemblages rich in Dicoelosia, present in the Ydw Member [e.g. 6f, 6g] are interpreted as some of the deepest in the Llandovery area (Cocks et al. 1984; cf. Jin \& Copper, 1999). The biota present in the Chwefri Formation, including its suite of soft-bodied burrowers (Davies et al. 2009), testifies to bottomset deposition beyond the colonizing reach of bottom-dwelling shelly benthos, along the margin of the planktonic graptolitic realm that characterized the deep-water Welsh Basin to the northwest.

Lower (Rhuddanian-Aeronian) parts of the succession have previously been viewed as pro-delta deposits (M. A. Woollands, unpub. Ph.D. thesis, Univ. College, London, 1970; Cocks et al. 1984). However, the dominant, bioturbated, foreset facies compare with those formed in the modern 'transition zone' located between parts of the coastal shoreface dominated by tractional processes and the distal shelf (Reineck \& Singh, 1975; Van Wagoner et al. 1990; Martin \& Pollard, 1996; Bann \& Fielding, 2004). Along lowenergy coastlines, and where rates of sediment supply permit, the upper limit of this zone of intense burrowing can occur in depths as shallow as $2 \mathrm{~m}$, whereas its lower reach can extend to depths of over $40 \mathrm{~m}$. In this context, the prograde sequences that make up the Llandovery succession would record the repeated advance of transition zone facies across deeper, more distal and less bioturbated offshore deposits.

The scarcity of tractional sedimentary structures within the sand-prone facies suggests that the higher energy shoreface facies that should cap each progradational sequence are poorly represented. This may in part record the transgressive truncation of the upper parts of these sequences, a process described by Weise (1980), but an additional or alternative explanation is that the Llandovery systems were decapitated by active faulting along the eastern margin of the outcrop, a structural zone now represented by the Pen-y-waun Fault Belt (Figs 1, 6). The observed progradational sequences accumulated and were preserved to the west of this fracture zone, whereas the expected shallower facies may have accumulated on, but were regularly eroded from, the adjacent footwall high. Preserved remnants of these more proximal topset facies are represented by the Derwyddon Formation of the 


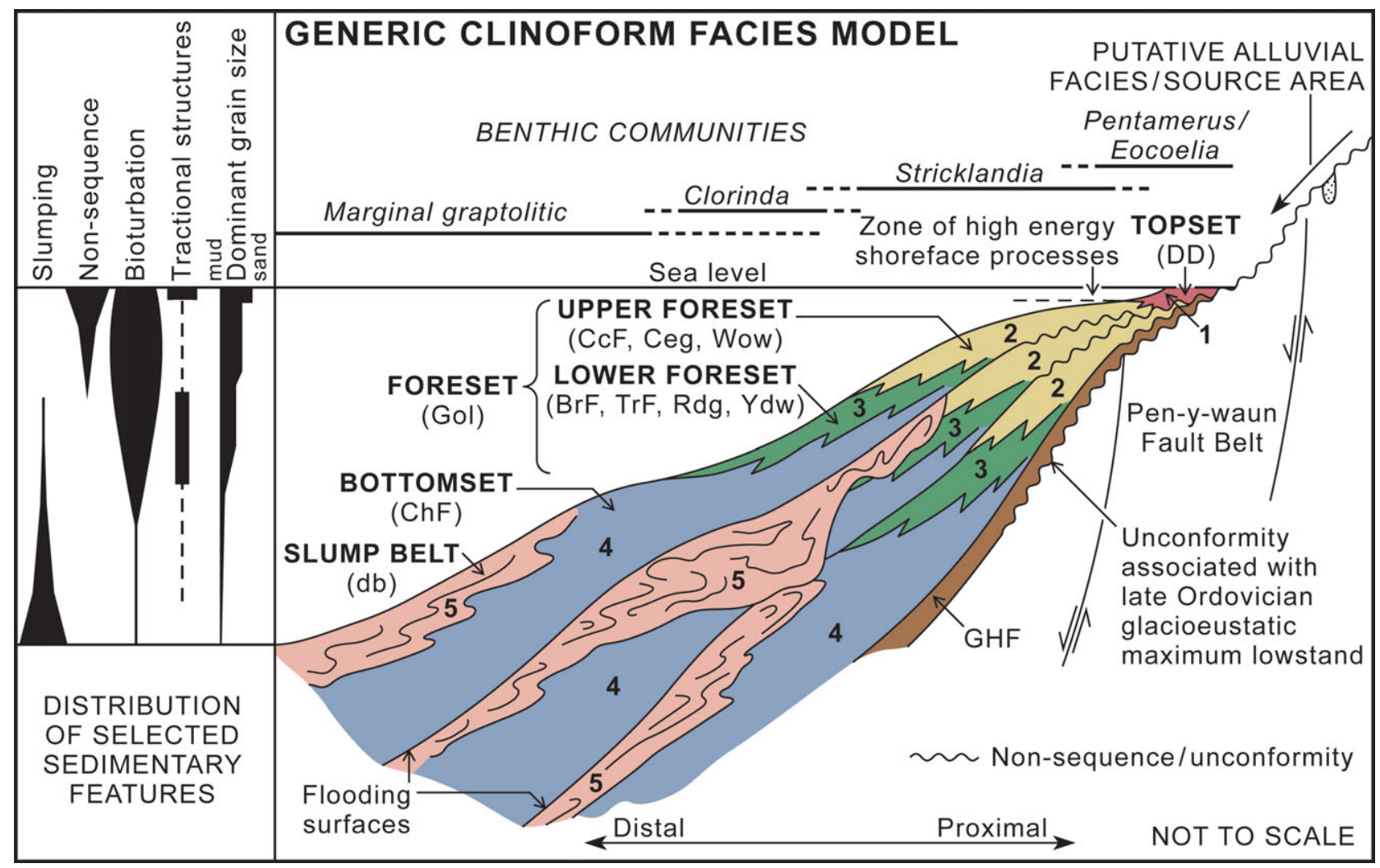

Figure 6. (Colour online) Generic clinoform facies belt model for the Type Llandovery succession showing prograde relationships and dominant lithologies: 1 - topset sandstones; 2 - upper foreset muddy sandstones; 3 - lower foreset sandy mudstones; 4 - bottomset silty mudstones; 5 - slump/slide-disturbed strata; excluding upper slope Tycwtta Mudstones Formation facies. See Figure 7 for lithological details and Figure 2 for key to lithostratigraphical symbols.

Pen-y-waun area and parts of the strongly overstepping and attenuated Wormwood Formation in the south (Fig. 8). In these areas, though bioturbation remained a periodically important process, sandstones with pentamerid brachiopod coquinas (Fig. 5e), and preserving cross-stratification and vertical escape traces, testify to the prevalence of tractional reworking in a shallow-water setting (Figs 4F, 5d, 6).

Building on this fault-controlled model, an alternative explanation for the observed facies patterns is to evoke the repeated progradation of sand-prone fan delta deposits across offshore bottomset muds. In this context, the homogenized foreset facies that dominate much of the Llandovery succession (Figs 6,7) can be radically re-interpreted as the product of mass flow and resedimentation on a fan delta surface, with bioturbation a secondary or overprinting factor. The concept of in situ benthic communities would need urgently to be revisited were this depositional model to find favour. In common with the shoreface model, proximal topset facies recording alluvial deposition and the effects of shallow-water, wave and tidal reworking would have been anchored to the erosionprone, footwall region; in which case the models of Westcott \& Etheridge (1990) and Postma (1990) may prove relevant. It is anticipated that ongoing studies will resolve these contrasting facies models.

The intertonguing, sand-prone, foreset facies die out towards a central region to the east of Llandovery town where the thickest, uninterrupted Chwefri Formation succession is developed. This area of deeper, offshore deposition was also the site of sea bed instability, as recorded by the presence of extensive units of slumped and disturbed strata (Facies belt 5) (Figs 3, 8). Each of the major progradational events has an associated slump complex associated with it suggesting that elevated rates of sedimentation contributed to the growth of over-steepened and unstable gradients; contemporaneous movements on major faults perhaps provided a seismic trigger. The back scars of some slumps migrated into more proximal facies belts (Figs $4 \mathrm{E}, 10)$ and, accordingly, though many slump units comprise disturbed bottomset mudstone, others include large masses of displaced, upper foreset sandstone.

In the upper part of the succession, where it is unaffected by later, slide-related, deformation, the Telychian Cerig Formation records more widespread offshore mud deposition. Thin sandstone beds, including those that are abundant in the Mwmffri Sandstone Member, were emplaced by storm-generated gravity flows below storm wave base.

\section{3.c. Sequence stratigraphy}

The new architecture clearly picks out a series of prograde sequences on a variety of scales; and yet smaller scale parasequences are recognized in measured sections (e.g. Davies et al. 2011). If recast 


\begin{tabular}{|c|c|c|c|c|c|c|}
\hline $\begin{array}{l}\text { Clinoform } \\
\text { facies belts }\end{array}$ & $\begin{array}{l}\text { Principal component lithologies } \\
\text { (inc. typical relative percentages) }\end{array}$ & $\begin{array}{l}\text { Formation/ } \\
\text { member }\end{array}$ & $\begin{array}{l}\text { Principal sedimentary } \\
\text { structures }\end{array}$ & $\begin{array}{l}\text { Benthic } \\
\text { communities }\end{array}$ & $\mathrm{BI}$ & $\begin{array}{l}\text { Selected trace } \\
\text { fossils }\end{array}$ \\
\hline \multirow{2}{*}{$\stackrel{1}{\text { TOPSET }}$} & $\begin{array}{l}\text { Sandstone, medium-bedded, } \\
\text { medium- to coarse-grained (95) }\end{array}$ & \multirow{2}{*}{ DD, Wow } & \multirow{2}{*}{$\begin{array}{l}\text { Cross-stratification; } \\
\text { pentamerid brachiopod } \\
\text { coquinas; common } \\
\text { burrow-mottling }\end{array}$} & \multirow{2}{*}{$\begin{array}{l}\text { Pentamerus and } \\
\text { Eocoelia }\end{array}$} & \multirow{2}{*}{$2-4$} & \multirow{2}{*}{$\begin{array}{l}\text { Skolithus, } \\
\text { Diplocraterion }\end{array}$} \\
\hline & $\begin{array}{c}\text { Pebble and granule conglomerate } \\
(2-5)\end{array}$ & & & & & \\
\hline \multirow{3}{*}{$\begin{array}{l}2 \\
\text { UPPER } \\
\text { FORESET }\end{array}$} & $\begin{array}{l}\text { Sandstone, intensely bioturbated, } \\
\text { thick-bedded, fine- to } \\
\text { medium-grained, with dispersed } \\
\text { granules and pebbles (20) }\end{array}$ & \multirow{3}{*}{$\begin{array}{l}\text { CcF, Ceg, } \\
\text { Wow, Gol }\end{array}$} & \multirow{3}{*}{$\begin{array}{c}\text { Pervasive burrow-mottling; } \\
\text { parallel- and } \\
\text { cross-lamination only } \\
\text { common in thin sandstone } \\
\text { beds; pebble and granule } \\
\text { lags }\end{array}$} & \multirow{3}{*}{$\begin{array}{l}\text { Pentamerus and } \\
\text { Stricklandia }\end{array}$} & \multirow{3}{*}{$4-5$} & \multirow{3}{*}{$\begin{array}{l}\text { Teichichnus, } \\
\text { Palaeophycus, } \\
\text { Planolites, } \\
\text { Zoophycus, } \\
\text { Chondrites }\end{array}$} \\
\hline & $\begin{array}{l}\text { Muddy sandstone, intensely } \\
\text { bioturbated, thick-bedded, fine- to } \\
\text { medium-grained, with dispersed } \\
\text { granules and pebbles (70) }\end{array}$ & & & & & \\
\hline & $\begin{array}{l}\text { Sandstone as thin, sharp-based } \\
\text { beds and laminae with bioturbated } \\
\text { tops }(2-10)\end{array}$ & & & & & \\
\hline \multirow{3}{*}{$\begin{array}{l}3 \\
\text { LOWER } \\
\text { FORESET }\end{array}$} & $\begin{array}{c}\text { Sandy mudstone, strongly } \\
\text { bioturbated, medium-bedded, with } \\
\text { dispersed coarse sand grains and } \\
\text { granules (85) }\end{array}$ & \multirow{2}{*}{$\begin{array}{l}\text { BrF, TrF, } \\
\text { Rdg, Gol, } \\
\text { Yst, Ydw }\end{array}$} & \multirow{3}{*}{$\begin{array}{l}\text { Pervasive burrow-mottling } \\
\text { (sparse in Ydw); parallel- } \\
\text { and cross-lamination only } \\
\text { common in thin sandstone } \\
\text { and siltstone beds }\end{array}$} & \multirow{2}{*}{$\begin{array}{c}\text { Stricklandia, } \\
\text { Clorinda and } \\
\text { marginal graptolitic }\end{array}$} & \multirow{2}{*}{$3-4$} & \multirow{2}{*}{$\begin{array}{l}\text { Thalassinoides, } \\
\text { Planolites, } \\
\text { Zoophycus, } \\
\text { Chondrites }\end{array}$} \\
\hline & $\begin{array}{l}\text { Sandstone as thin, sharp-based } \\
\text { beds and laminae with bioturbated } \\
\text { tops }(2-10)\end{array}$ & & & & & \\
\hline & $\begin{array}{l}\text { Silty mudstone with thin, weakly } \\
\text { bioturbated sandstone and } \\
\text { siltstone beds and laminae (5) }\end{array}$ & Ydw & & \begin{tabular}{|c|} 
Clorinda \\
(Dicoelosia-rich); \\
marginal graptolitic
\end{tabular} & $2-3$ & $\begin{array}{l}\text { Zoophycus, } \\
\text { Chondrites }\end{array}$ \\
\hline \multirow{2}{*}{$\stackrel{4}{4}$ BOTTOMSET } & $\begin{array}{l}\text { Mudstone, silty, thin-bedded with } \\
\text { diffuse colour banding (90) }\end{array}$ & \multirow[b]{2}{*}{ ChF } & \multirow{2}{*}{$\begin{array}{l}\text { Poorly preserved } \\
\text { hemipelagic lamination; } \\
\text { sparse burrow-mottling; } \\
\text { minor slump-related } \\
\text { convolutions }\end{array}$} & \multirow[b]{2}{*}{ Marginal graptolitic } & \multirow[b]{2}{*}{$1-2$} & \multirow{2}{*}{$\begin{array}{c}\text { Chondrites } \\
\text { (small diameter) }\end{array}$} \\
\hline & $\begin{array}{l}\text { Thin, unbioturbated beds and } \\
\text { laminae of sandstone and } \\
\text { siltstone }(2-10)\end{array}$ & & & & & \\
\hline \multirow{3}{*}{$\stackrel{5}{\text { SLUMP BELT }}$} & $\begin{array}{l}\text { Disturbed bottomset mudstone } \\
(75-95)\end{array}$ & \multirow{3}{*}{$\begin{array}{c}\mathrm{db} \\
\text { (locally } \\
\text { affects most } \\
\text { formations) }\end{array}$} & \multirow{3}{*}{$\begin{array}{c}\text { Slump folds and convolute } \\
\text { bedding; listric surfaces; } \\
\text { basal and internal slide } \\
\text { planes }\end{array}$} & \multirow{3}{*}{\multicolumn{3}{|c|}{ Not applicable }} \\
\hline & $\begin{array}{c}\text { Mélange/debrite - mudstone with } \\
\text { ill-sorted angular and rounded } \\
\text { clasts }(5-20)\end{array}$ & & & & & \\
\hline & $\begin{array}{l}\text { Large displaced rafts of other } \\
\text { facies belt lithologies (dominant in } \\
\text { some slump complexes) }\end{array}$ & & & & & \\
\hline
\end{tabular}

Figure 7. (Colour online) Summary lithological data for the Type Llandovery succession (excluding Garth House, Tycwtta Mudstones and Cerig formations). Facies belt numbers refer to Figures 6 and 8; BI - bioturbation index of Taylor \& Goldring (1993).

as a chronostratigraphical section, using graptolite biozones as a proxy for time, the new architectural and facies models permit, for the first time, the erection of a detailed sequence stratigraphy for the Type Llandovery succession (Fig. 8). Each progradation is shown to overlie a sequence-defining flooding surface and the scales and geometries of the progrades favour grouping the seven main Rhuddanian to Aeronian sequences into three composite or higher order sequences (sensu Duval, Cramez \& Vail, 1992). There are important variations in detail when compared with Jones (1925), but also clear echoes of his original $\mathrm{A}, \mathrm{B}$ and $\mathrm{C}$ scheme in this new analysis. The progradational acmes of these composite sequences occurred during the acinaces, lower convolutus and upper sedgwickii-halli graptolite biozones. The initial post-glacial maximum rise in sea level appears to have peaked during the persculptus Biozone, but the Llandovery succession was fashioned by further flooding events that achieved their maxima during the revolutus, middle convolutus and lower sedgwickii biozones. Significant secondary events include those linked to the local first appearances of revolutus and upper convolutus graptolite biozone assemblages.
Evidence of fault movements and differential subsidence testifies to local tectonic activity, but, in marked contrast to the Telychian, the influence of tectonism on the Hirnantian to Aeronian rock record in central Wales appears, on the whole, to have been insufficient fully to mask that of eustasy (Woodcock et al. 1996; Davies et al. 1997; Davies, Waters \& Copus, 1999; Schofield et al. 2009a). In the Llandovery area, two late Hirnantian age sequences record events in the immediate aftermath of the Late Ordovician glacial maximum lowstand, including the re-ventilation and faunal restocking of the Welsh Basin (Davies et al. 2009). However, work on Gondwanan sequences, particularly in South America, has confirmed that there were further periods of advance and retreat of the South Polar ice sheet throughout much of the early Silurian (e.g. Page et al. 2007; Caputo, 1998; Dias-Martinez \& Grahn, 2007) and it is the impacts of these events that are now widely accepted to account for perturbations in early Silurian sea level (e.g. Loydell, 1998). A comparison of Llandovery sea level curves (Fig. 9) is significantly hindered by calibration problems (e.g. Zhang \& Barnes, 2002; Johnson, 2010; Munnecke et al. 2010) that, in the short term at least, the findings presented herein are 


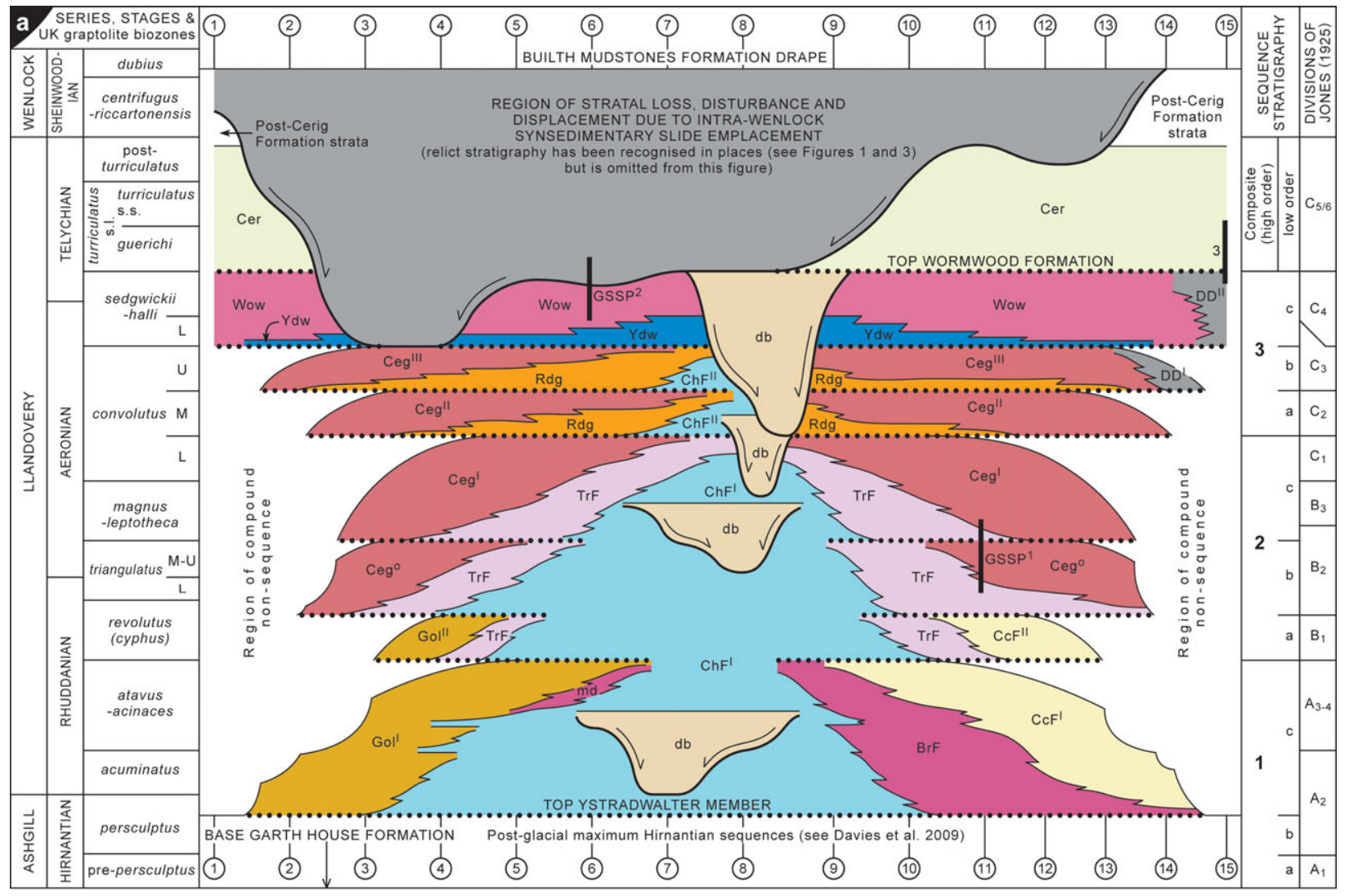

......... Major flooding surfaces $\quad$ Basal surfaces of synsedimentary slump/slide units

Key to facies belts in b: $\quad 1$ Topset facies $\quad 2 \begin{aligned} & \text { Upper and undivided } \\ & \text { foreset facies }\end{aligned} \quad 3$ Lower foreset facies $\quad 4$ Bottomset facies $\quad 5$ Slump belt facies

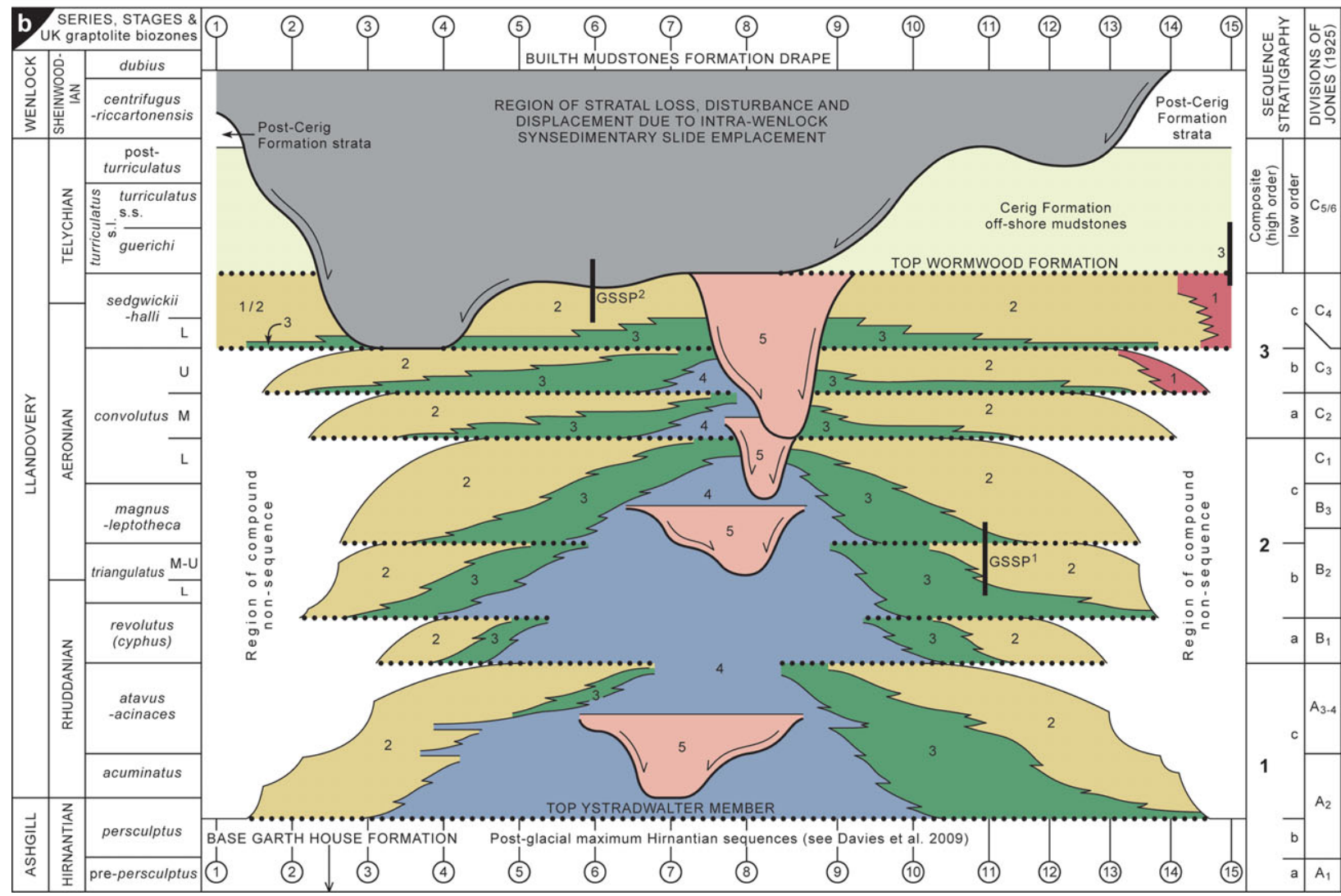

Figure 8. (Colour online) Generalized chronostratigraphical model and graptolite biostratigraphy for the pre-Cerig Formation Type Llandovery succession showing new prograde-based sequence stratigraphy and its relationship to: (a) local lithostratigraphy; and (b) clinoform facies belts. See Figures 2, 3 and 6 for key; GSSP ${ }^{1}$ - current Aeronian Stage Stratotype Section; GSSP ${ }^{2}$ - current Telychian Stage Stratotype Section; 3 - new Cerig Formation type section; acuminatus Biozone - ascensus-accuminatus Biozone of Zalasiewicz et al. (2009). 


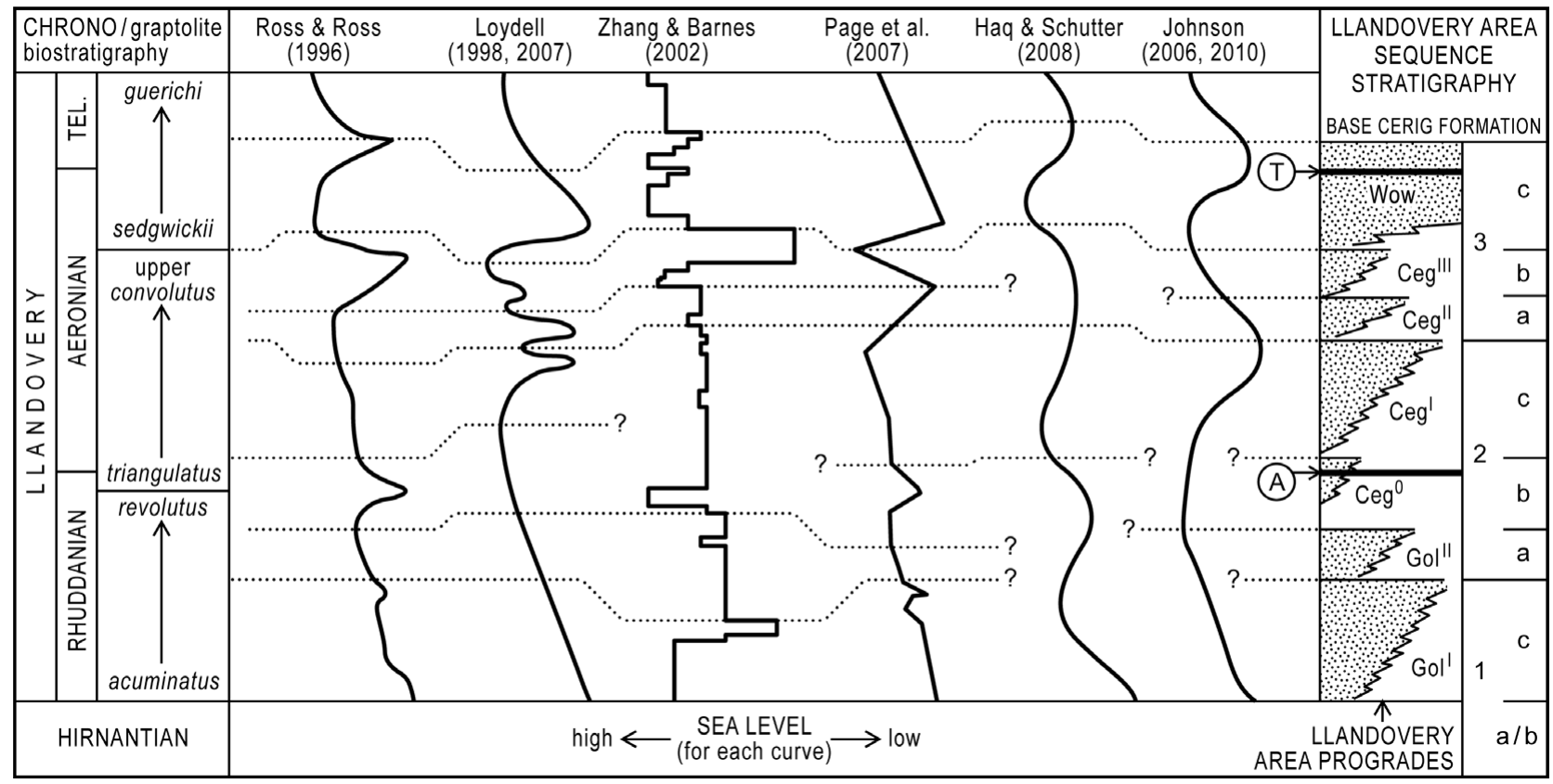

Figure 9. Rhuddanian to early Telychian sea level curves showing possible relationships to the newly erected Type Llandovery sequence stratigraphy (curve of Zhang and Barnes is simplified). Dotted lines - putative glacioeustatic flooding surfaces. N.B. aside from Page et al. (2007), curve alignments are as presented by Zhang \& Barnes (2002) (earlier curves) and Johnson (2010) (later curves), although alternative correlations for some key events are suggested. A - horizon of Aeronian GSSP; T - horizon of Telychian GSSP; acuminatus Biozone-ascensus-accuminatus Biozone of Zalasiewicz et al. (2009).

likely further to compound (see Section 5). Differences in methodology and scale account for most difficulties, but differences in the timing of regional onset flooding verses global maximum flooding can also account for what appear to be major discrepancies between the regional and global datasets. Notwithstanding these problems, recent syntheses appear to acknowledge higher order eustatic regressions with acmes in the mid Aeronian (convolutus Biozone) and late Aeronianearly Telychian (Fig. 9). Evidence for an early to mid Rhuddanian regression is less clear, although several curves record a small-scale, pre-revolutus Biozone lowstand event. There is still less consensus about the timing and scale of secondary (lower order) regressions, though there is evidence of up to five such events between the latest Rhuddanian and end Aeronian. The precise correlations suggested in Figure 9 will doubtless be debated, but, within current dating constraints, glacioeustatic forcing culminating in emergence and erosion is seen to offer a ready explanation for many of the Llandovery area progrades. Conversely, the key flooding surfaces can be linked to intervening interglacial highstands (Fig. 9).

The revolutus Biozone has been widely cited as marking a period of enhanced coarse clastic input to the Welsh Basin and its marginal shelf that was out of step with global eustasy (e.g. Davies \& Waters, 1995; Schofield et al. 2009a). But this study shows that, in keeping with eustatic events, the sand-rich CrychanGoleugoed system contracted and was abandoned during this interval, inviting re-evaluation of its basinal correlatives. However, the overall distribution of sandprone, Rhuddanian foreset facies testifies to separate periods of local progradation (Figs 3, 8b) that, in their timing and duration, were not fully consistent with the pattern of post-glacial deepening that most sea level curves depict (Fig. 9). It is to explain this and other discrepancies that the additional influence of local tectonism can be invoked (cf. Zhang, Barnes \& Jowett, 2006). Though eustatic events can account for the timing of many Llandovery area sequences, local patterns of progradation are likely also to reflect the flux in sediment supply that stemmed from the emergence and deep erosion of up-faulted tracts to the east; and during some intervals this was perhaps the dominant factor.

The eustatic credentials of the marked guerichi Biozone flooding event recorded by the base of the Cerig Formation are also less certain. The Telychian was a period of enhanced regional subsidence and tectonic activity in Wales during which eustasy appears largely to have been overridden as the dominant control on sedimentation (Woodcock et al. 1996; Davies et al. 1997). Newly discovered synsedimentary slides and associated disturbance also makes sequence analysis of the upper part of the succession problematic (Figs 3, 8). Despite this, a detailed, well-dated Rhuddanian to Aeronian sequence stratigraphy is now available for the Llandovery Series's type succession to aid with the calibration and diagnosis of global models.

\section{3.d. Stratal loss in the Type Llandovery area}

When traced into proximal northern and southern regions of the Type Llandovery area, each prograde has a correlative unconformity and, in the most proximal 


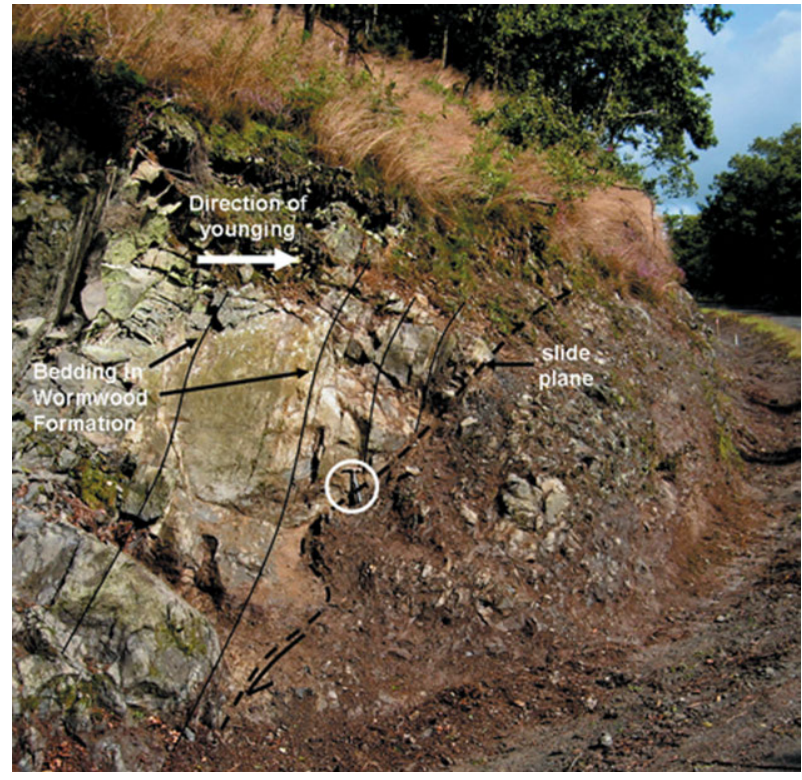

Figure 10. (Colour online) Mélange with blocks of sandstone (right) overlying basal slide plane of major synsedimentary slump truncating bedding in the Wormwood Formation (left), Glyn-moch track section [SN 8174 3751], Crychan Forest. Note strata are structurally inverted and young to the right; hammer for scale, circled, is $0.28 \mathrm{~m}$ long.

settings, these merge to produce surfaces of compound non-sequence (Fig. 8). Here, angular overstep relationships (Figs 1, 3) confirm that fault-influenced uplift, tilting and bevelling was an important factor, in a similar manner to that described by Gawthorpe et al. (2000) (Fig. 6). Overstepping relationships beneath the upper Hirnantian Garth House Formation record the impact of the Late Ordovician glacioeustatic lowstand and associated deep erosion (Davies et al. 2009). The extensive erosion surface that caps the main Goleugoed-Crychan progradation represents the A/B unconformity of Jones (1925). A major non-sequence is recognized at a level broadly equivalent to the base of Jones' $\mathrm{C}_{2}$ division that only locally equates to his $\mathrm{B} / \mathrm{C}$ unconformity (Fig. 8). In marked contrast to Jones $(1925,1949)$ and Cocks et al. (1984), the current study recognizes the transgressive base of the Wormwood Formation and the correlative parts of the Derwyddon Formation (Fig. 4F) as a key overstep surface, broadly equivalent to the sub- $\mathrm{C}_{4}$ unconformity recognized by Jones \& Williams (1949).

The recognition of extensive slumped units and, particularly in the upper part of the succession and in the Wenlock, of regional-scale slide surfaces with associated zones of disturbance, shows that other processes have contributed to strata loss and displacement in the area (Figs 8, 10). Nevertheless, the central belt does appear to preserve an essentially intact Rhuddanian to Aeronian succession, and it is in this region that the strategy of dating the newly recognized flooding events (see Section 4) has had the greatest success.

\section{Biostratigraphy}

Key to understanding the architecture of the adjacent, deep-water, Welsh Basin succession was the systematic use of graptolite biostratigraphy (e.g. Zalasiewicz, 1990; Loydell, 1991; Davies et al. 1997). In an effort to replicate this success, and to establish a common biostratigraphical framework for regional correlation and event calibration, graptolites were also targeted for collection from the shelf facies of the Llandovery area. Systematic sampling for acritarchs and chitinozoans was also undertaken. Deficiencies in earlier sampling regimes were also addressed; for example, the focus for much of the graptolite work undertaken by Cocks et al. (1984) was in the north, whereas reported acritarch assemblages came from the south (Hill \& Dorning, 1984).

A review of the extensive published faunal lists for the Type Llandovery area has also been undertaken, and these continue to provide data essential for local, regional and international correlation. In all, more than 400 micro- and macrofossil assemblages have been analysed during this study, including over 100 new assemblages. Those assemblages that are key to the erection of the new architectural model are plotted on Figure 11 and detailed in Appendix 1. This analysis has allowed the strengths and weaknesses of existing biozonal schemes to be evaluated and, by adopting a 'first appearance datum' (FAD) and 'last appearance datum' (LAD) approach, underpins a radically revised cross-correlation of the separate macro- and microfossil biozonal schemes for the Llandovery Series in its type area (see Section 6). A more detailed biostratigraphical database, including taxonomic analysis of the new macro- and microfossil discoveries, will be published elsewhere.

\section{4.a. Graptolites}

Given the oxic and bioturbated nature of much of the succession, the deeper and more offshore facies, associated with the flooding events, were considered to provide the best taphonomic window for graptolite preservation, and proved productive (Fig. 11). It is important not to understate the difficulties of recovering graptolites from the Type Llandovery succession. They are extremely sparse, whilst their fragmentary nature commonly hinders identification. Nevertheless, targeted collecting has significantly increased the number of well-dated graptolite localities (Figs 11, 12, 13; Appendix 1). Ten additional Llandovery taxa have been recognized, bringing the total reported from the Llandovery area to 55. Additional persculptus Biozone and Wenlock taxa are also reported. The assemblages reported by Jones (1925) and Cocks et al. (1984) have been re-assessed and some of the most critical re-examined. All the newly reported graptolite assemblages are curated in the collections of the British Geological Survey, Keyworth, Nottingham, UK. 


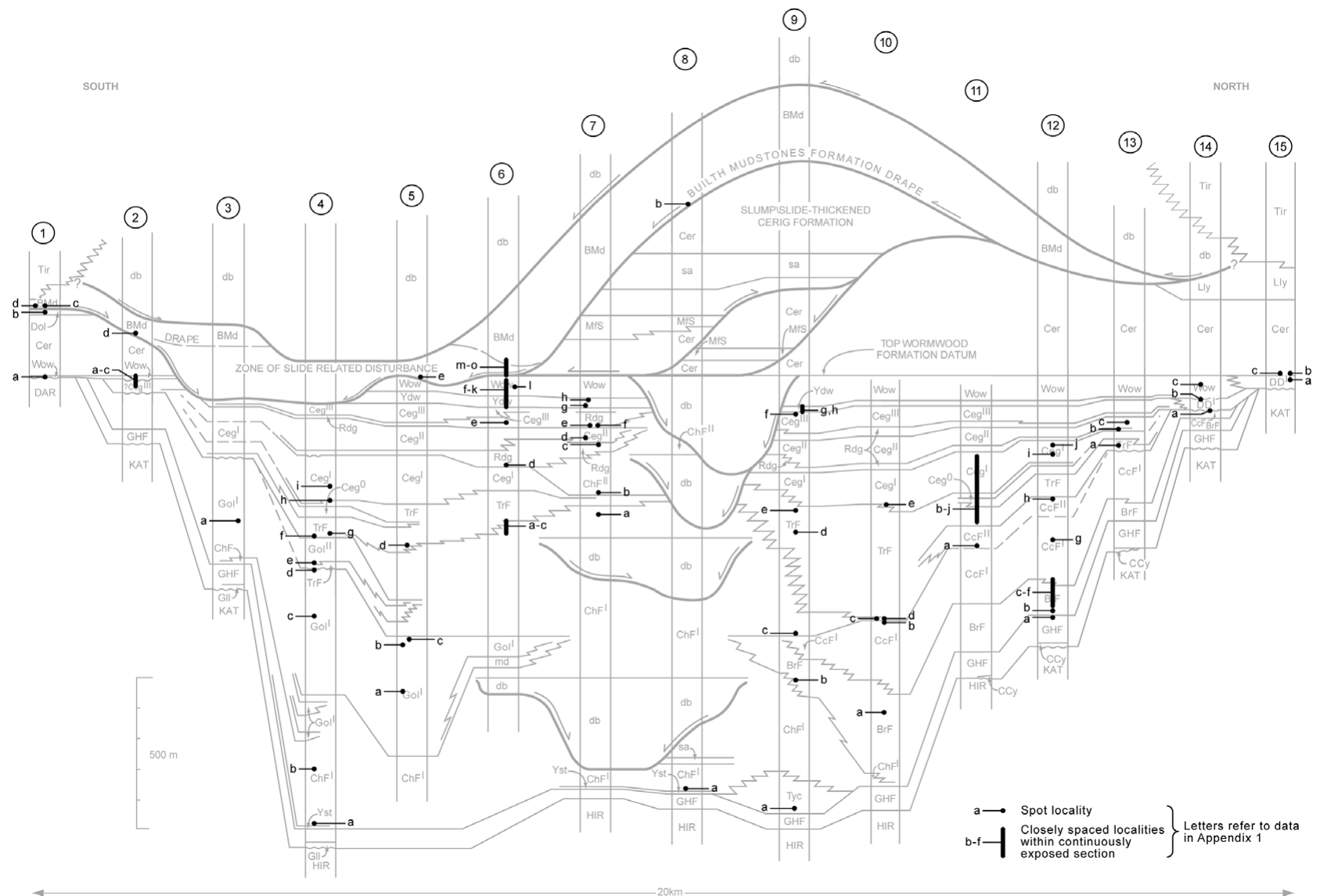

Figure 11. Selected fossil localities in the Type Llandovery area; see Appendix 1 for details.

The findings of this new work, when placed in the context of the new sequence stratigraphical framework, have allowed the FADs of many of the key Rhuddanian and Aeronian graptolite biozonal assemblages to be plotted throughout the area (Fig. 8), though no such resolution is possible for Telychian strata (see Section 5.d). In assessing the graptolite faunas, the revised UK range charts and biozonal nomenclature of Zalasiewicz et al. (2009) have been used. A comparison of this UK scheme with those in use elsewhere is provided by Loydell (2011). Use of the revolutus Biozone in place of the cyphus Biozone marks a significant change from earlier published practice for the Llandovery of Wales. Former usage of the turriculatus Biozone in Wales, for example by Cocks et al. (1984) and Davies et al. (1997), has also changed. The guerichi Biozone now occupies the lower part of this interval. The term turriculatus Biozone s.l. (sensu lato) has been used in recent accounts to signify the original Welsh usage and for reference purposes (e.g. Schofield et al. 2004, $2009 \mathrm{~b}$ ). Graptolites distinctive of the lower [e.g. 9e] and upper parts [e.g. 7e] of the convolutus Biozone have been recovered from the Llandovery area. Assemblages indicative of the 'middle' part of the zone have been recognized in mid Wales (Davies et al. 1997), but use of this term in the Llandovery area is largely informal.

Many of the newly plotted FADs are associated with flooding events, and it appears intuitively correct that each transgression has the potential to introduce newly evolved species. However, since it was these levels that were specifically targeted for collection, the discovery of biostratigraphically distinct assemblages from successive flooding levels may reflect this sampling bias; and it is a truism worth restating that local FADs of biozonal assemblages need not represent true biozonal bases in the strictest sense, or occur at precisely the same stratigraphical level everywhere.

Late Hirnantian persculptus Biozone graptolites are unknown below the base of the Chwefri Formation and its correlatives; it is at this level that the biozone's most primitive morphs first appear in Wales (Blackett et al. 2009; Davies et al. 2009). A key discovery, contradicting Jones (1925) and Cocks et al. (1984), is that sedgwickii Biozone assemblages first appear in the Ydw Member of the Wormwood Formation (see Section 3.a and Fig. 17). The FAD of Neolagarograptus tenuis $[9 \mathrm{~g}]$ and, in its upper part, the LAD of Raphidograptus toernquisti [9h] suggest the member spans the lower part of the biozone, and this is supported by the presence in underlying strata of probable upper convolutus Biozone graptolites [e.g. 7e]. A specimen of Paradiversograptus runcinatus from the Cerig Formation (Cocks et al. 1984, p. 148) has been lost, but the discovery of Spirograptus guerichi from close to the base of the formation (Fig. 13) confirms that this marks the local FAD of guerichi Biozone taxa. No younger Llandovery graptolites have been recovered in the type 

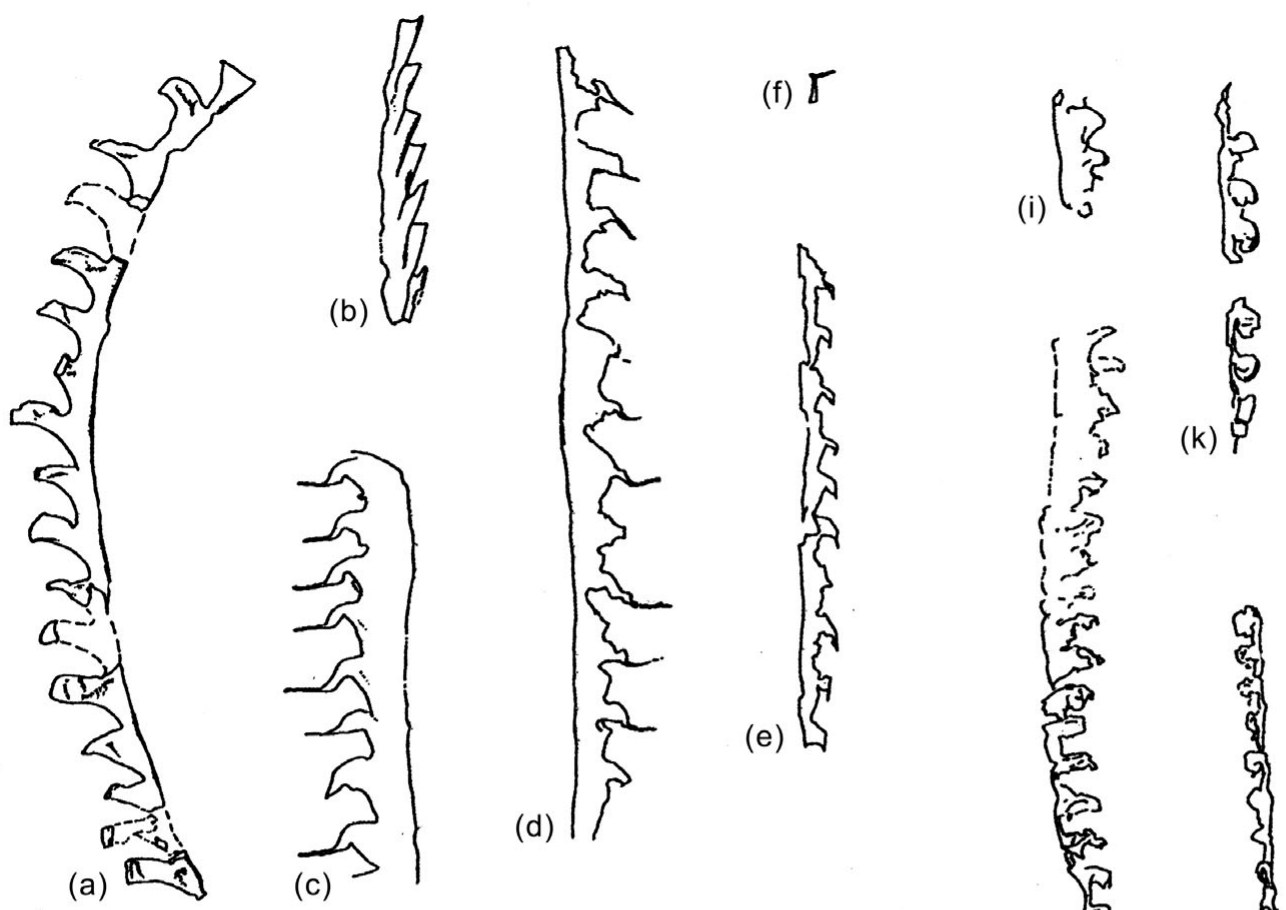

(m)<smiles>C1=C2CCC(=C1)C2</smiles>

(q)

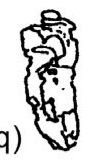

(e) 1
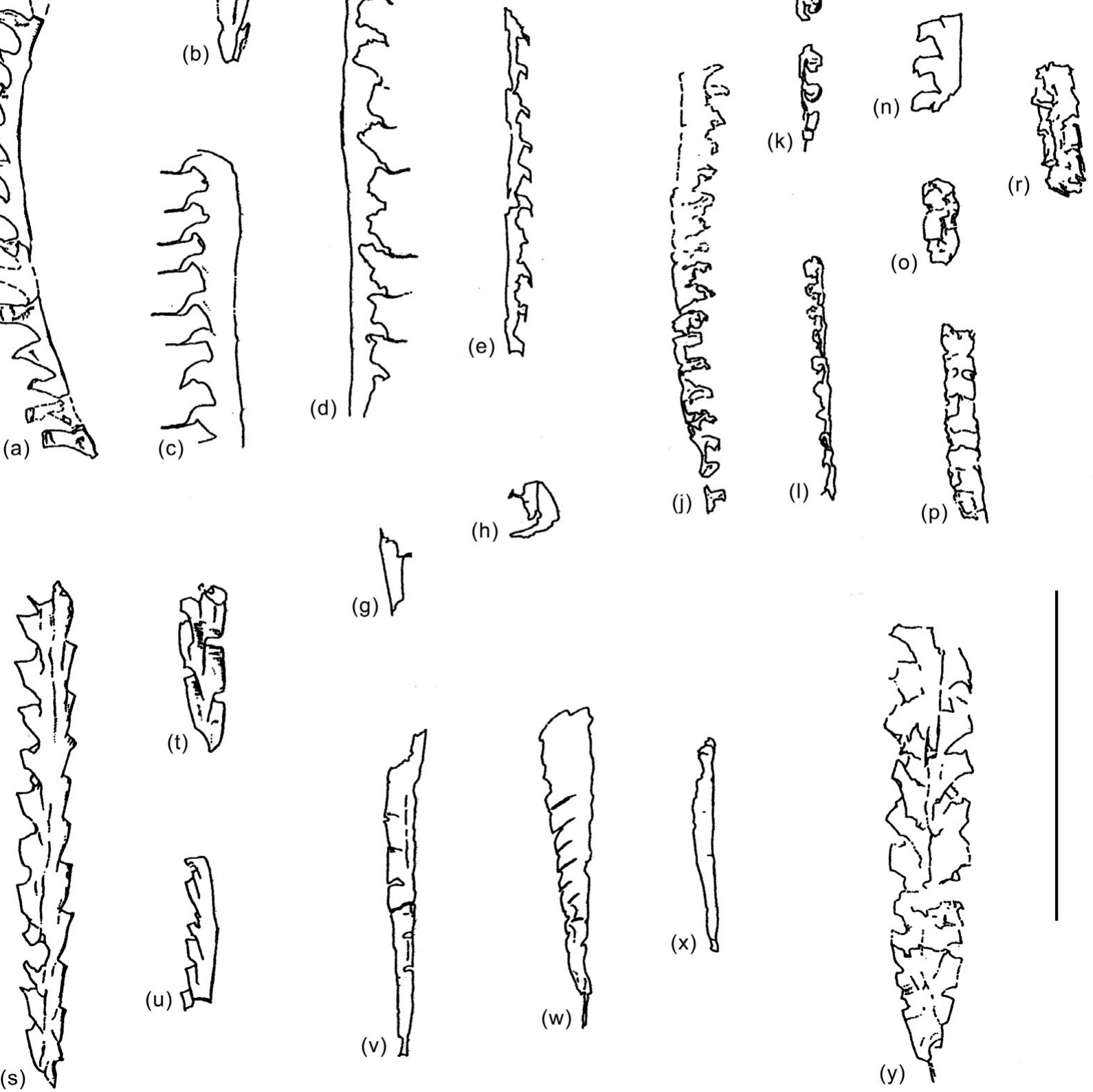

(g)
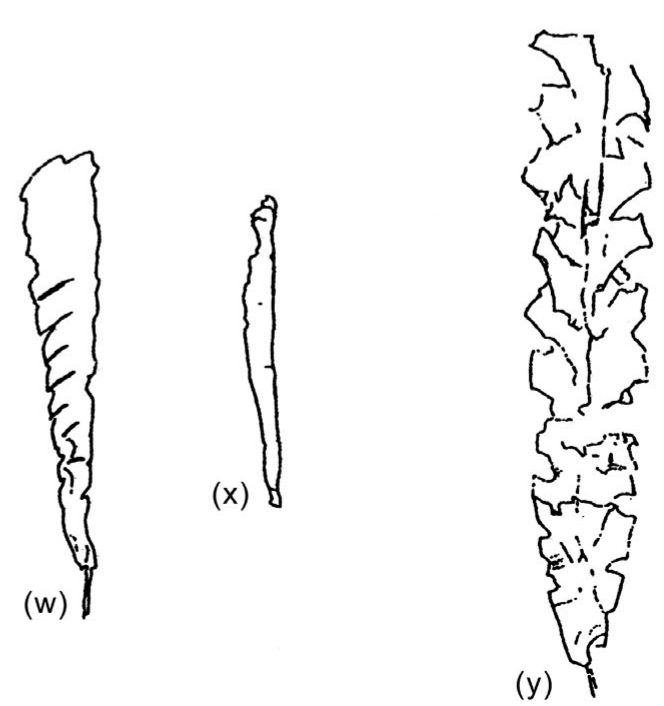

Figure 12. Examples of new Rhuddanian and Aeronian graptolite discoveries in the Type Llandovery area (locality numbers refer to Fig. 11 and Appendix 1). (a) Torquigraptus cf. magnificus, [2c], BGS JZB4187; (b) Pristiograptus cf. regularis, [2c], BGS JZB4185; (c) Stimulograptus sedgwickii, [2c], BGS JZB4185; (d, e) Stimulograptus sedgwickii, [9g] (d) JZB4171, (e) BGS JZB4172; (f) Rastrites sp. (gracilis?), sicula and th1, [9g], BGS JZB4172; (g, h) Neolagaragraptus cf. tenuis (h as predated fragment?), [9g], both BGS JZB4172; (i-n) cf. Campograptus harpago, [7e], (i) BGS JZB4082, (j) BGS JZB4073, (k) BGS JZB4084, (1) BGS JZB4070, (m) BGS JZB4099, (n) BGS JZB4097; (o-r) cf. Metaclimacograptus undulatus, [7e], (o) BGS JZB4097, (p) BGS JZB4085, (q) BGS JZB4082, (r) BGS JZB4086; (s) Glyptograptus cf. tamariscus varians, [9c], BGS JZB4114; (t) Normalograptus sp., [9c], BGS JZB4115; (u) Atavograptus cf. atavus, [9c], BGS JZB4114; (v-x) Rhaphidograptus toernquisti, [4g], (v) BGS JZB4167, (w) BGS JZB4156, (x) BGS JZB4165; (y) Normalograptus cf. wyensis, [5d], BGS JZB4104. Scale bar = $1 \mathrm{~cm}$, except $(\mathrm{o}-\mathrm{t})$ and $(\mathrm{y})=$ $5 \mathrm{~mm}$.

area, but in the nearby Garth area (Fig. 1) Schofield et al. (2004) recorded griestoniensis, crenulata, spiralis and post-spiralis biozone assemblages below strata yielding basal Wenlock centrifugus and murchisoni biozone graptolites. New assemblages from Wenlock strata overlying the Type Llandovery succession (Fig. 14; Appendix 1) reveal the absence here of early Wenlock biozones (see Section 5.e). 


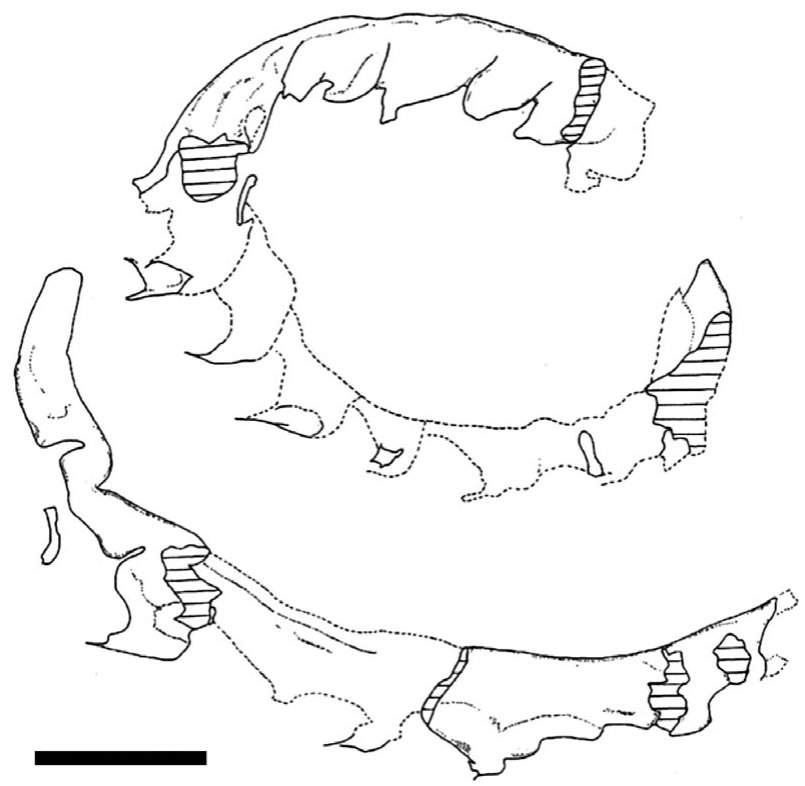

Figure 13. Spirograptus guerichi (BGS MWL6435), $3 \mathrm{~m}$ above base of the Cerig Formation at its revised type section [15b]. Scale bar $=1 \mathrm{~mm}$.

\section{4.b. Brachiopods}

Key studies of late Hirnantian and Llandovery brachiopod assemblages and lineages, including those from the Llandovery area, are those by Jones (1928), Williams (1951), Zeigler (1966), Cocks (1968, 1970, 1978), Cocks et al. (1984), Baarli (1986) and Temple (1987). No systematic re-assessment of the taxonomic work of these authors has been attempted as part of the current study. However, the new mapping and architectural model allows the stratigraphical distributions of the key taxa to be re-evaluated (Section 6).

Facies locally preserved below the Garth House Formation, deposited during the Late Ordovician glacial maximum, contain the distinctive cold water 'Hirnantia Fauna' (Woodcock \& Smallwood, 1987). In Wales, as elsewhere, elements of this assemblage locally survive the post-glacial FAD of persculptus Biozone graptolites (Davies et al. 2009). In Llandovery strata, key transitions within the Stricklandia lens, Eocoelia and newly plotted Meifodia prima and Plectatrypa tripartita lineages can be related to key flooding surfaces and the FADs of graptolite assemblages. Species of Clorinda, Cryptothyrella, Leangella and Leptostrophia, and the generic transition from Borealis to Pentamerus are also important. Critically, it emerges that the ranges of key taxa within the important Eocoelia and Stricklandia lineages overlap within the Wormwood Formation. The evolutionary successions $E$. hemispherica $\rightarrow E$. intermedia $\rightarrow E$. curtisi and $S$. lens progressa $\rightarrow$ S. laevis may not be compromised, but the FADs of successor species appear not always to coincide with the LADs of their precursor forms. Moreover, all these transitions appear to predate the local FAD of guerichi Biozone graptolites (cf. Doyle, Hoey \& Harper, 1994; also Floyd \& Williams, 2003). The genera Eospirifer and Pentlandella also have their local FADs in the Wormwood Formation, below and above the Telychian GSSP, respectively [6f, 6k].

Perhaps most significantly, it is now known that a key 'Telychian' assemblage of Cocks et al. (1984), including E. curtisi and S. laevis, came from a raft in a Wenlock synsedimentary mélange (see Section 5.d) [6n]. The relevance of specimens transitional between $E$. curtisi and the more advanced E. sulcata in the Sawdde Gorge, associated with the only record of Costistricklandia lirata from the Llandovery area (Hurst, Hancock \& McKerrow, 1978) [1b], must also be viewed with caution as the absence of early Wenlock strata [1c] suggests there is doubt whether the strata here have fully escaped the effects of Wenlock sliderelated disturbance.

\section{4.c. Acritarchs}

An acritarch biozonal scheme was established for the Type Llandovery area by Hill \& Dorning (1984) and modified slightly by Dorning \& Bell (1987). Further modifications were made by Davies et al. (1997) when applying the scheme to the Welsh Basin succession. The data of Hill \& Dorning (1984) have been recalibrated using the revised architecture and augment extensive new acritarch collections from the Llandovery area. Over 70 assemblages have been assessed and the 98 taxa now identified include over 30 newly recognized in the Llandovery area. A selection of the newly recovered specimens is shown in Figure 15. Slides and residues of all the newly reported acritarch assemblages are registered and curated in the MPA series of the British Geological Survey, and figured specimens are stored in the MPK collection of Type and Figured micropalaeontological specimens. Both collections are housed at the British Geological Survey, Keyworth, Nottingham, UK.

Unlike the graptolite dataset, sampling for acritarchs was not restricted to flooding horizons, and the data obtained do not suffer from the same limitations. Even so, many of the key microfloral events coincide with regional and likely global flooding surfaces. The biozonation erected by Hill \& Dorning remains relevant, but the positions of their biozonal boundaries (FADs) relative to the standard Llandovery graptolite biozonation are significantly revised (Fig. 19). Other microfloral incomings suggest their scheme is capable of refinement. The entry of species of Domasia, Visbysphaera and Salopidium above the earliest Cefngarreg Sandstone prograde $\left(\mathrm{Ceg}^{0}\right)$ could provide the basis for a local division of the eoplanktonica Biozone, and the upper part of the estillis Biozone is distinguished by the FADs of species of Cymatiosphaera, Dilatisphaera and Micrhystridium in the Wormwood and Derwyddon formations [e.g. 2c, 15a].

The recovery of the biozonal marker Gracilisphaeridium encantador from the basal Cerig Formation in the Derwyddon area [15c] shows that its FAD coincides with that of guerichi Biozone graptolites and 


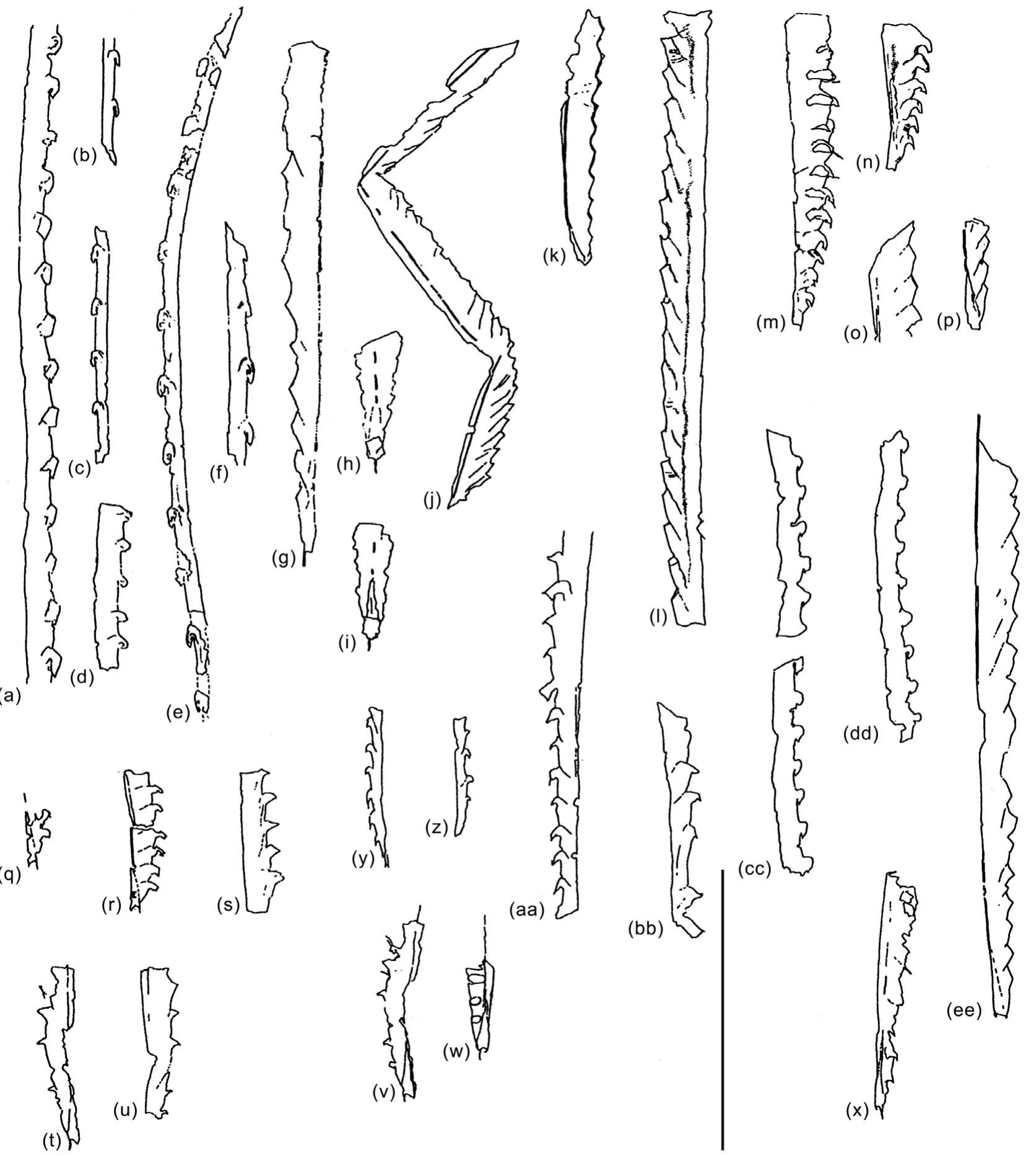

Figure 14. Examples of Wenlock graptolite discoveries in the Type Llandovery area (locality numbers refer to Fig. 11 and Appendix 1). (a-f) aff. Mediograptus retroflexus, [2d], (a) BGS JZB4209, (b) BGS JZB4206, (c, d) BGS JZB4205, (e) BGS JZB4199, (f) BGS JZB4200; (g-i) Pristiograptus ex. gr. dubius (h, i, dorsal aspect), [2d], (g) BGS JZB4231, (h) BGS JZB4213, (i) BGS JZB4212; (j) Pristiograptus dubius pseudolatus (predated?), [2d], BGS JZB4207; (k) Pristiograptus ex. gr. dubius, [1c], BGS JZB4037; (1) cf. Monoclimacis flumendosae [1c], BGS JZB4035; (m, n) Monograptus $\mathrm{cf}$. priodon, [1d], (m) BGS JZB4008, (n) BGS JZB4002; (o, p) Pristiograptus ex. gr. dubius, [1d], (o) BGS JZB4011, (p) BGS JZB4009; (q-s) Monograptus riccartonensis, [6m], (q) BGS MWL6276, (r) BGS MWL6285, (s) BGS MWL6276; (t-v, x) Monograptus cf. riccartonensis, [6o], (t, v) BGS JZB4069, (u) BGS JZB4055, (x) BGS 4065; (w) cf. Pristiograptus ex. gr. dubius, [6o], BGS JZB4058; (y, z) Monograptus aff. riccartonensis of Zalasiewicz \& Williams (1999), [6m], (y) BGS JZB4052, (z) BGS JZB4053; (aa, bb) Monograptus cf. riccartonensis, [6m], (aa) BGS JZB4051, (bb) BGS JZB4050; (cc, dd) cf. Mediograptus retroflexus, [7i], (cc) BGS JZB4247, (dd) BGS JZB4246; (ee) Pristiograptus ex. gr. dubius, [7i], BGS JZB4247. Scale bar $=1 \mathrm{~cm}$, except $(\mathrm{j})=2 \mathrm{~cm}$.

is earlier than originally thought (Davies et al. 1997). Of particular note, however, is that the two 'Telychian' localities $(163,223)$ of Hill \& Dorning (1984) are now shown either to be of Wenlock age and/or to have been affected by synsedimentary sliding. This means that the Deunffia monospinosa Biozone assemblage cannot be 


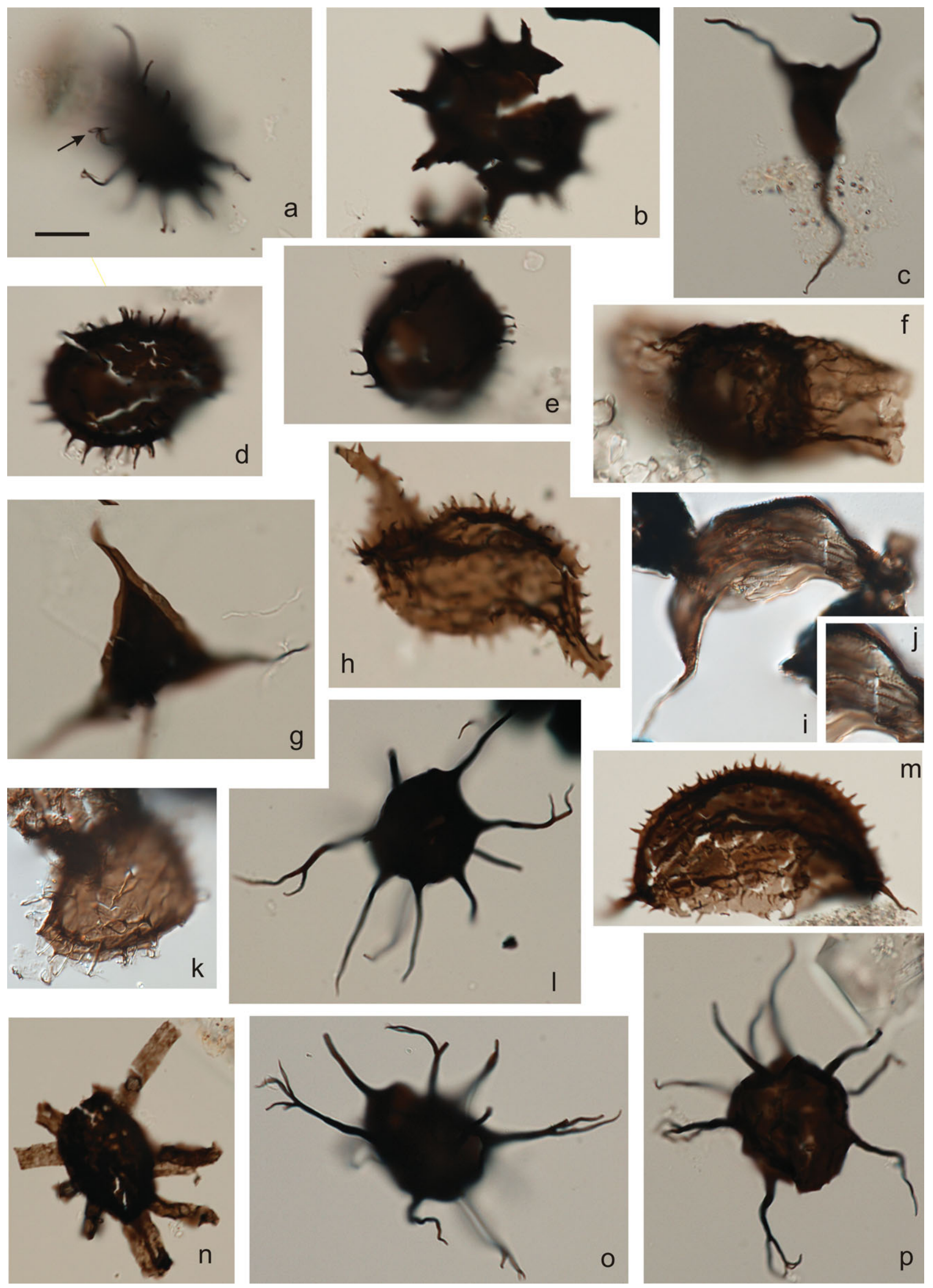

Figure 15. (Colour online) Examples of acritarchs from the Type Llandovery area. Information for each specimen includes: specimen number (prefixed MPK), sample number (prefixed MPA), slide number and England Finder co-ordinates (e.g. R31/3) (locality numbers [in square brackets] refer to Fig. 11 and Appendix 1). Specimens are stored in the MPK collection of Type and Figured 
used to define the Telychian stratotype as proposed by Cocks et al. (1987). In both the Welsh Borderland and the Welsh Basin, such assemblages, including the index taxon, first appear in upper Telychian strata (Davies et al. 1997).

\section{4.d. Chitinozoans}

For Llandovery strata, the preliminary findings of De Permentier \& Verniers (2002) have been revisited and augment those of this study. The upgraded database of over 50 assemblages, comprising 47 identified taxa, underpins a detailed chitinozoan biozonation for the Llandovery area succession based on the global scheme for the Silurian erected by Verniers et al. (1995) and Verniers' (1999) scheme for the Wenlock of the Builth Wells area. A selection of the newly recovered forms is shown in Figure 16. All newly reported chitinozoan specimens, and rock samples used for chitinozoan studies, are stored at the Research Unit Palaeontology, Ghent University, Krijgslaan 281 (Building S8), Belgium.

Assemblages of the electa, maennili and dolioliformis biozones are all recognized. The highest dolioliformis Biozone assemblage obtained to date underlies the FAD of guerichi Biozone graptolites, but this biozone is known elsewhere in Wales to extend into younger Telychian strata (e.g. Mullins \& Loydell, 2002). Late margaritana Biozone assemblages show strata previously regarded as Telychian to be of Wenlock age (Davies et al. 2011). The early Llandovery fragilis and postrobusta biozones, anticipated in strata below the FAD of electa Biozone assemblages [12f], have as yet not been proven. However, poorly preserved Hirnantian chitinozoans have been recovered from the base of the Garth House Formation (this study), and a similar assemblage from its top (T. J. Challands, unpub. Ph.D. thesis, Durham Univ., 2008) has been tentatively attributed to the taugourdeaui Biozone [12a]. These faunas are in the process of revision and, currently, firm observations for this biozone and its index fossil in the Welsh basin are restricted to the Bala area of mid Wales (Vandenbroucke, 2008; Vandenbroucke et al. 2008). As with the acritarchs, sampling for chitinozoans was not restricted to flooding levels. Nevertheless, the FADs of many key taxa closely overlie newly identified flooding surfaces, and a cross-correlation of the Type Llandovery acritarch and chitinozoan biozonation reveals significant coincidence (Fig. 19).

Precursor forms of some key biozonal species have also been identified and their FADs may be significant. Specimens recognized as Eisenackitina cf. dolioliformis, for example, first appear in strata of magnus-leptotheca graptolite Biozone age that overlie the earliest Cefngarreg Sandstone prograde $\left(\mathrm{Ceg}^{0}\right)$ [e.g. 4h, 11f] and permit the local subdivision of the maennili Biozone (Fig. 19).

\section{4.e. Other fossils}

Cocks et al. (1984) provided details of a conodont assemblage from the Bronydd Formation [10a] recognized as indicative of the Icriodella discreta-I. deflecta Assemblage Biozone (Fig. 19). Burgess (1991) recorded spores of the membranifera-Pseudodyadospora sp. B Biosubzone in strata ranging from the Hirnantian Garth House Formation to the lower part of the Aeronian Wormwood Formation. Spores of the succeeding avitus-dilatus Biozone first appear in the upper part of the Wormwood Formation [6j], but below the Telychian GSSP (Fig. 19). The locations of key assemblages in these biozones are included in Appendix 1.

\section{Chronostratigraphy}

\section{5.a. Concept and evolution}

Since Murchison (1867), there has been widespread acceptance that an upper division of the Type Llandovery succession oversteps a lower part (Jones, 1921). Jones (1925) was the first to suggest that the lower unit itself comprised two separate units and to refer to the three 'Divisions or Stages' as (A) Lower, (B) Middle and (C) Upper Llandovery (Figs 2, 17). These earlier works were of their time in presenting a conflation of rock and time stratigraphical concepts. The drive to improve international correlation of Llandovery rocks persuaded Cocks, Toghill \& Zeigler (1970) to give formal and biostratigraphical definition to four

micropalaeontological specimens of the British Geological Survey, Keyworth, Nottingham, UK. Scale bar in (a) $=10 \mu \mathrm{m}$ for all except (j). (a) Gracilisphaeridium encantador Cramer ex Eisenack et al. 1973, MPK 14233, MPA 51448, slide 2, R31/3, looped process termination is arrowed, [15c]; (b) Tylotopalla robustispinosa (Downie) Eisenack et al. 1973, MPK 14234, MPA 55430, slide 1, K58/0, [7a]; (c) Domasia limaciformis (Stockmans \& Willière) Cramer, 1970, MPK 14235, MPA 55432, slide 1, J62/0, [7b]; (d) Ammonidium cf. listerii Smelror, 1987, MPK 14236, MPA 55432, slide 1, U38/0, [7b]; (e) Ammonidium cf. listerii, MPK 14237, MPA 55432, slide 1, S49/0, [7b]; (f) Carminella maplewoodensis Cramer, 1968, MPK 14238, MPA 55435, slide 1, H41/4, [7f]; (g) Beromia rexroadii Wood, 1996, MPK 14239, MPA 55435, slide 1, R53/0, [7f]; (h) Dactylofusa estillis Cramer \& Díez de Cramer, 1972, MPK 14240, MPA 55447, slide 2, G49/3, [14c]; (i, j) Eupoikilofusa rochesterensis Cramer ex Eisenack et al. 1976, MPK 14241, MPA 55442, slide 1, F65/0, (j) detail of ornament, [11d]; (k) Tunisphaeridium parvum Deunff \& Evitt, 1968, MPK 14242, MPA 55447, slide 2, G60/2, [14c]; (1) Multiplicisphaeridium cf. fisherii (Cramer) Lister, 1970, MPK 14243, MPA 55443, slide 1, G63/0, [11e]; (m) Dactylofusa estillis, MPK 14244, MPA 55447, slide 2, P44/3, [14c]; (n) Dilatisphaera laevigata Lister, 1970, MPK 14245, MPA 55449, slide1, J52/1, [15a]; (o) Multiplicisphaeridium cf. fisherii, MPK 14246, MPA 55443, slide 1, N51/4, [11e]; (p) Multiplicisphaeridium cf. fisherii, MPK 14247, MPA 55443, slide 1, F70/0 [11e]. 


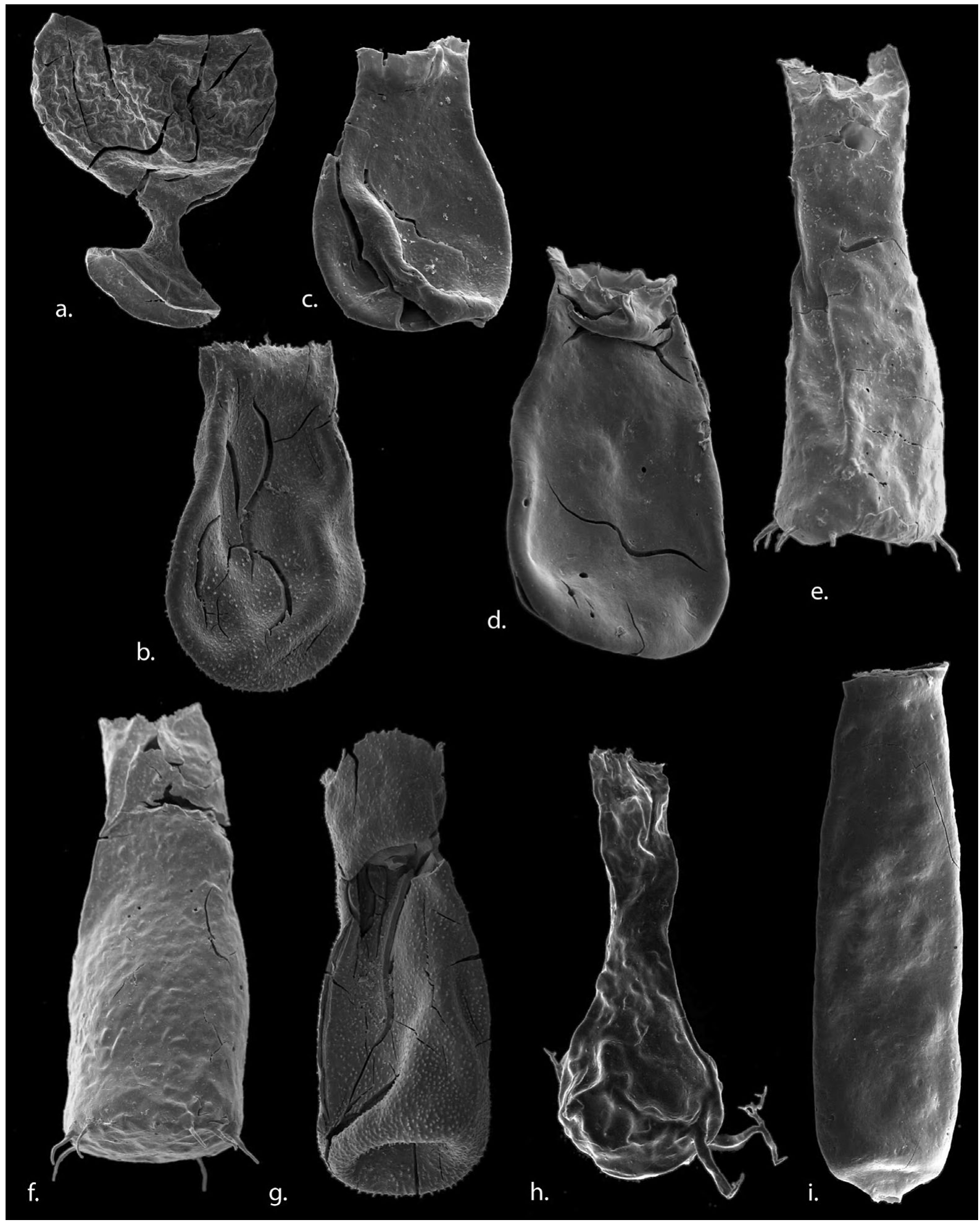

Figure 16. Examples of chitinozoans from the Type Llandovery area. Sample numbers refer to Ghent University databases (locality numbers [in square brackets] refer to Fig. 11 and Appendix 1). (a) Margachitina margaritana, length $=0.100 \mathrm{~mm}, 08-1967$, [6m]; (b) Belonechitina ?aspera, length $=0.145 \mathrm{~mm}, 08-1997$, [10b]; (c) Eisenackitina ithoniensis, length $=0.110 \mathrm{~mm}, 09-2184$, [6n]; (d) Eisenackitina dolioliformis, length $=0.140 \mathrm{~mm}, 08-1984$, [7f]; (e) Spinachitina maennili, length $=0.165 \mathrm{~mm}, 08-1993$, [7c]; (f) Spinachitina maennili, length $=0.175 \mathrm{~mm}, 08-1993$, [7c]; (g) Belonechitina postrobusta, length $=0.210 \mathrm{~mm}, 08-1997$, [10b]; (h) Ancyrochitina sp., length $=0.130 \mathrm{~mm}, 08-1982$, [11d; 1.1-1.2 $\mathrm{m}$ below Aeronian GSSP]; (i) Conochitina proboscifera, length = $0.420 \mathrm{~mm}, 09-2184$, [6n].

Llandovery divisions. The Lower Llandovery was defined as the Rhuddanian Stage, the Middle became the Idwian, and the Upper was divided into the Fronian and younger Telychian stages. The subsequent require- ment for chronostratotypes to be located in sections that provide a record of uninterrupted deposition and to be based on internationally applicable criteria (see Holland, 1989) heralded the next phase of revision. 


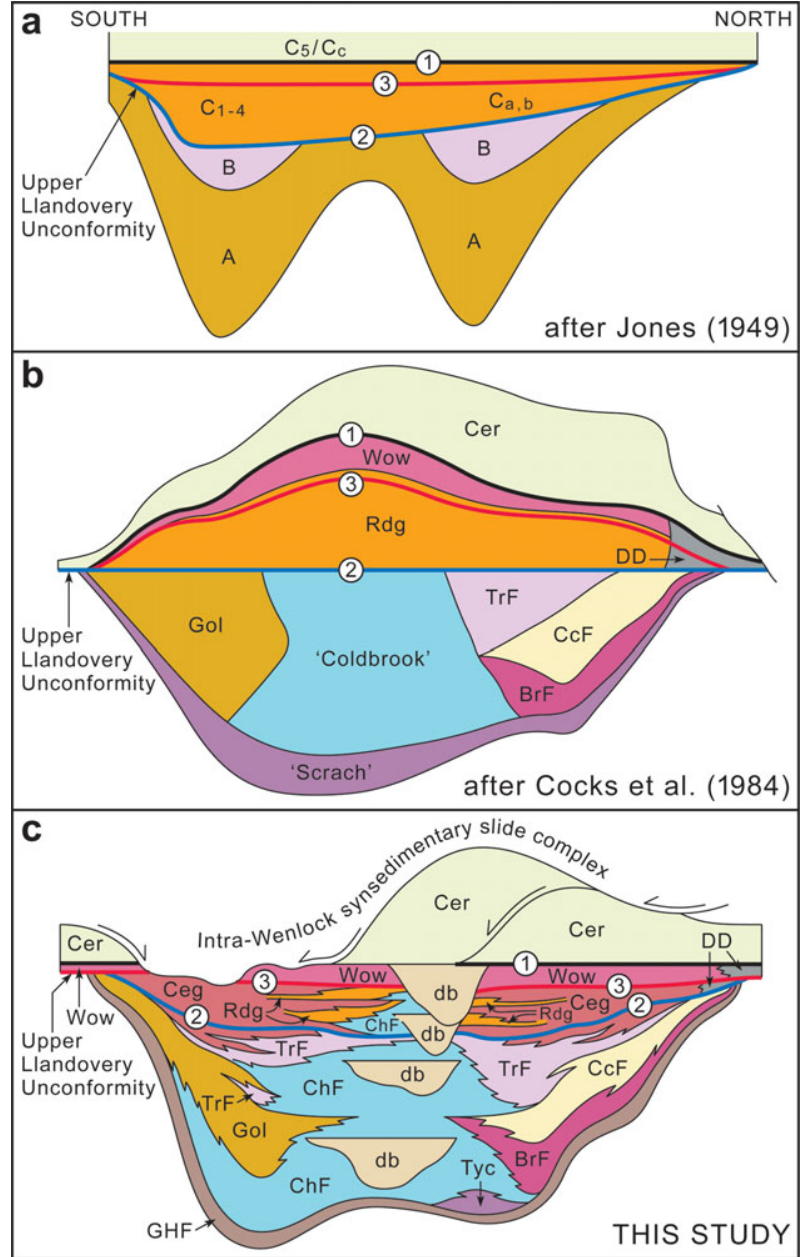

Figure 17. (Colour online) A comparison of former architectural models for the Type Llandovery succession with that presented by this study showing the relative positions of key datums and their relationship to the Upper Llandovery unconformity (and overstep) of early workers; (a) after Jones (1949); (b) after Cocks et al. (1984); and (c) this study (simplified from Fig. 3). 1 - top Wormwood Formation datum; 2 - FAD of sedgwickii Biozone graptolites as envisaged by Jones and Cocks et al.; 3 - FAD of sedgwickii Biozone graptolites as shown by this study. N.B. the position of datum 3 in (a) and (b) is indicative only as it lies in the upper part of Jones's $\mathrm{C}_{3}$ division and Cocks et al.'s Rhydings Formation (see text).

Responding to the recommendations of the Silurian Subcommission and a perceived need to define just three divisions of 'more nearly' equal duration, Cocks et al. (1984) erected the current three stages and, in doing so, moved the Telychian GSSP from the base of the Wormwood Formation (their usage) to a point in its upper part.

Since its first recognition in the Llandovery area, the position and use of the sedgwickii graptolite Biozone has been of particular interest (Fig. 17). Jones $(1925,1949)$ considered the base of his $C$ division $\left(\mathrm{C}_{1}\right.$ subdivision) to mark the unconformable base of Murchison's Upper Llandovery (Figs 2, 17). Graptolites recovered from the southern Llandovery area suggested to him that the base of this unit was of sedgwickii Biozone age (Jones, 1925, p. 383) (Fig. 17, datum
2). Cocks, Toghill \& Zeigler (1970) and Cocks et al. (1984) failed to challenge this interpretation; it informed the definition of the former Fronian Stage, and continues to inform the published ranges of many key Llandovery Series taxa (e.g. Bassett, 1989; Bassett \& Rong, 2002). The current study shows that the FAD of sedgwickii Biozone graptolite assemblages is much higher in the succession, within the Ydw Member (Fig. 17, datum 3). Paradoxically, however, it is the strongly overstepping base of this latter unit, and its correlatives in the north and south of the type area, that represents the Upper Llandovery unconformity of earlier workers (Fig. 17). The former widespread use of the term $C_{1}$, notably in the Welsh Borderland (e.g. Zeigler, Cocks \& McKerrow, 1968), but also internationally (e.g. Johnson, Rong \& Yang, 1985), is no longer sustainable in terms of implying a like for like correlation with the Type Llandovery succession. However, where applied solely as a label for the sedgwickii Biozone, the correlation implied by its previous use may remain valid.

The case for retaining an 'Upper Llandovery Stage' (sensu Murchison, 1867; Jones, 1921, 1925), defined by the entry of sedgwickii Biozone graptolites and correlative faunas, has been made by Temple (in Cocks et al. 1984, p. 164). The improved understanding presented here shows that several key brachiopod taxa (E. hemispherica, S. lens intermedia, S. lens progressa) and acritarch assemblages (microcladum, estillis), previously viewed as correlative proxies for the sedgwickii Biozone in the Llandovery area, are present in strata now known to pre-date both the FAD of sedgwickii Biozone graptolites and the 'Upper Llandovery' unconformity of earlier workers. However, the faunal flux recognized within the Wormwood Formation, including first appearances of acritarch species, spore assemblages, alongside brachiopod genera (Eospirifer, Pentlandella) and species of Stricklandia, Eocoelia, Leptostrophia and Leangella, suggests that a mixed assemblage can be defined that allows widespread correlation of the sedgwickii Biozone flooding event, underpinning its credentials as a possible alternative stage boundary.

\section{5.b. Base Silurian System, Llandovery Series and Rhuddanian Stage}

In 1985, the Silurian Subcommission formally moved the base of the Silurian System from the base of the persculptus graptolite Biozone to the base of the succeeding Parakidograptus acuminatus Biozone, which, following the work of Melchin, Cooper \& Sadler (2004), is now referred to as the ascensus-acuminatus Biozone (Zalasiewicz et al. 2009). In the Llandovery area, this had the effect of removing from the Llandovery units previously included in it by Jones $(1925,1949)$ and Williams (1951). The implications of this change of definition are discussed by Davies et al. (2009) in their re-assessment of these strata. Graptolites of the persculptus and 

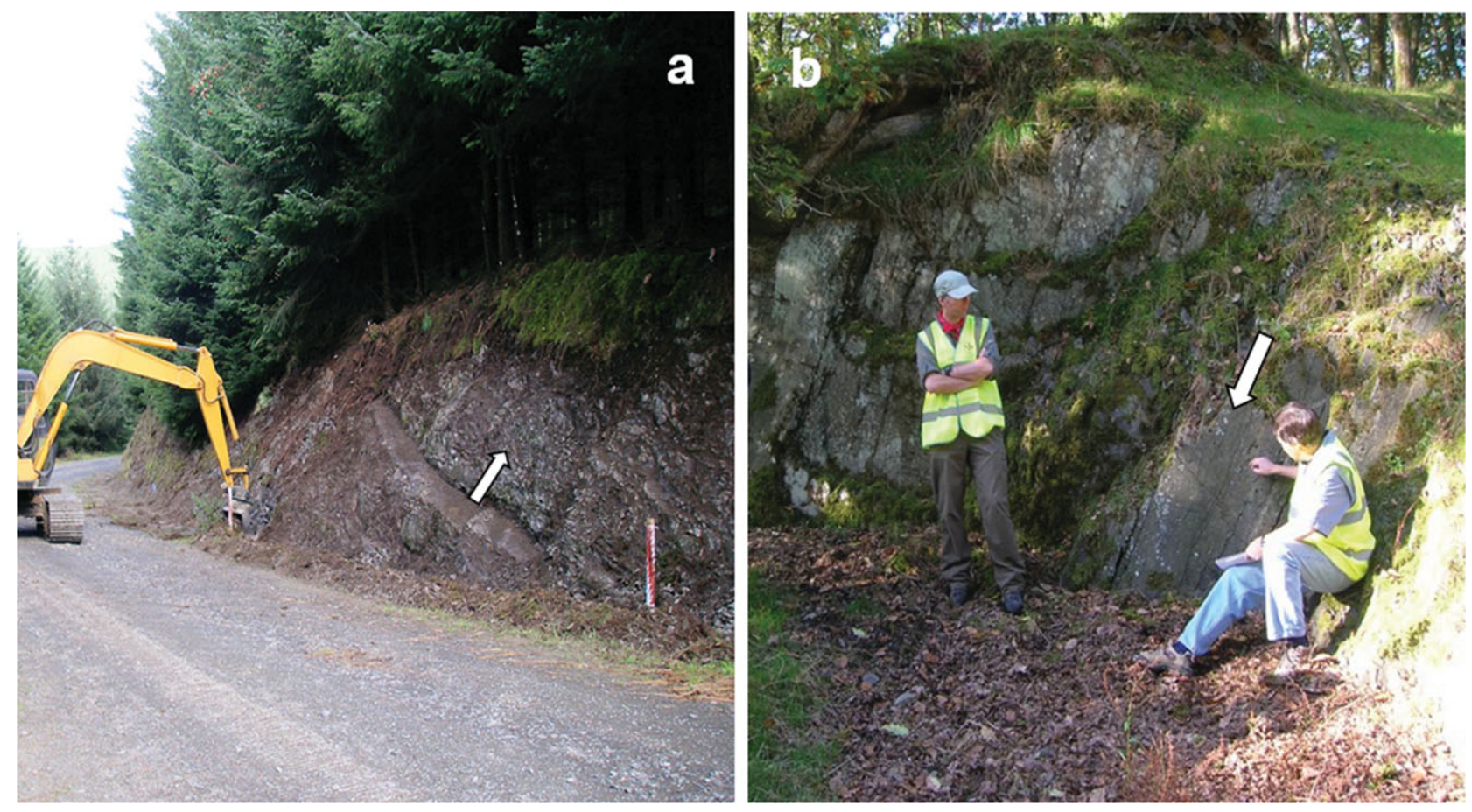

Figure 18. (Colour online) GSSPs in the Llandovery area: (a) Current Aeronian GSSP (arrowed; perpendicular to bedding) [SN 8382 3955], Cefngarreg Sandstone Formation ( $\mathrm{Ceg}^{0}$ ) (formerly Trefawr Formation; see text), Trefawr track section, Crychan Forest; (b) current Telychian GSSP (arrowed; parallel to bedding) [SN 7742 3233], Wormwood Formation, Cefn Cerig quarry (strata young towards left).

atavus-acinaces biozones have been recorded in the Llandovery area (Appendix 1) and exposures exist which must contain the base of the intervening ascensus-acuminatus Biozone (and hence of the series and system), but its precise location is currently unknown. The system boundary, and by default the Llandovery Series and Rhuddanian Stage boundaries, are defined at Dob's Linn in Scotland (Williams \& Ingham, 1989) and the need for an equivalent section in the Llandovery area, though desirable, is not essential. It should be noted, however, that the system boundary in the Llandovery area does not coincide with a significant sequence stratigraphical event. The linked glacioeustatic and climatic changes that initiated the global cycle of Silurian sedimentation are recorded by changes in sedimentary regime that occurred prior to the FAD of late Hirnantian persculptus Biozone graptolites in Wales (Fig. 7; Davies et al. 2009).

\section{5.c. Aeronian stratotype}

The biostratigraphical criterion used to define the base of the Aeronian Stage is the same as for the former Idwian Stage (Cocks, Toghill \& Zeigler, 1970; Cocks et al. 1984), i.e. the base of the gregarius graptolite Biozone (= base triangulatus Biozone). Cocks, Toghill \& Zeigler (1970) defined the base of the Idwian in the south of the type area at the unconformable $\mathrm{A} / \mathrm{B}$ contact of Jones (1925). However, to meet the requirements for modern GSSPs, Cocks et al. (1984) located the base of the new Aeronian GSSP in the north, within fossiliferous sandstones that they included in the Trefawr Formation, but which Davies et al. (2011) recognized as an early unit of the Cefngarreg Sandstone Formation $\left(\mathrm{Ceg}^{0}\right)$ (Figs 4C, 8, 18a). Temple (1988) has commented on the concepts and the inadequacy of the fossil data used to define the base of the triangulatus Biozone at the stratotype. Its location, at the base of Cocks et al.'s (1984) locality 72 in the Trefawr track section [11d], rests on the recovery of a single specimen of Monograptus austerus sequens from this horizon. The highest definitive revolutus graptolite Biozone assemblage, with M. austerus vulgaris, occurred over $18 \mathrm{~m}$ stratigraphically lower in the section [11c] (Fig. 4C). The conceptual issues raised by Temple are addressed by Holland \& Bassett (1988), and no additional macrofaunal data have been obtained as part of the current study. However, Zalasiewicz et al. (2009) now restrict the range of $M$. austerus sequens to the middle part of the triangulatus Biozone, indicating that the Aeronian GSSP lies within, rather than at the base, of that biozone. An assessment of the other faunas from the section (micro and macro) fails to show a significant turnover across the stratotype boundary.

The current work allows the relative positions of the former Idwian and current Aeronian stage boundaries to be compared accurately (Fig. 2) and shows that the former lies at a lower level in the stratigraphy marked by the FAD of revolutus Biozone graptolites in the Llandovery area. 


\section{5.d. Telychian stratotype}

The original Telychian stratotype of Cocks, Toghill \& Zeigler (1970) was located in roadside exposures north of Cefn Cerig (Cerrig) farm at the base of Jones's (1925) $\mathrm{C}_{4}$ division [c. 6g]. In an effort to realign the stage definition with what were perceived as more internationally applicable biostratigraphical criteria, Cocks et al. (1984) relocated the basal Telychian GSSP to Cefn Cerig quarry in the upper part of the Wormwood Formation where it underlay their roadside type section for the succeeding Cerig Formation (Figs 4D, 8, 18b). Temple (1988) again identified conceptual problems with the stratotype definition: it is located above the LADs of two key brachiopod taxa [6j], but, as this study confirms, no FADs can be shown to coincide with the GSSP. That the current GSSP broadly equates with the base of the turriculatus s.l. Biozone was also questioned (see Johnson, Kaljo \& Rong, 1991; Melchin, Cooper \& Sadler, 2004) and this study confirms that the Llandovery area FAD of guerichi (lower turriculatus s.l.) Biozone graptolites is at a higher level.

However, previous studies failed to recognize that this type section for the Cerig Formation displays the effects of dislocation associated with the emplacement of a major (tens of kilometres in width) intra-Wenlock synsedimentary slide complex (Figs 3, 8) (Davies et al. 2010, 2011). The basal slide surface lies about $25 \mathrm{~m}$ stratigraphically above the GSSP, but overlying it is a dated slice of mid Wenlock strata [6m] (Fig. 4D). This intervenes between the stage boundary and the locality from which Cocks et al. (1984) obtained their lowest 'Telychian' fauna [6n]. Reported as being from the Cerig Formation, this assemblage is now known to come from a raft within a sedimentary mélange and to be associated with material that contains Wenlock chitinozoans. The provenance of the key brachiopods (S. laevis and a primitive E. curtisi) present at this locality cannot now be proven, but the sandstone raft they came from is indistinguishable lithologically from underlying Wormwood Formation facies in which $S$. laevis is known to be present [e.g. 61]. These discoveries re-ignite the debate about the choice of the current Telychian GSSP and the criteria used in its selection (Temple, 1988) and make the case for an alternative that can be defined using more robust biostratigraphical data and in the choice of which chemostratigraphical techniques may also have a role to play (e.g. Cramer et al. 2010). The revised interpretation of the section also indicates that only thin, slide-bound and disturbed slices of true Cerig Formation are present in what is a clearly inappropriate type section (see Section 3.a).

\section{5.e. Base Wenlock Series in the Type Llandovery area}

Jones $(1925,1949)$ and Williams (1953) recognized the base of the Wenlock Series in the Llandovery area as one of their unconformities. Jones (1925) commented on the absence of early Wenlock graptolites from the lower levels of his Wenlock Series succession, but noted the presence of the mid Wenlock taxon 'Monograptus dubius'. In contrast, Cocks et al. (1984) cited 'Monoclimacis vomerina basilica' from a locality close to the base of their Gwernfelen Formation as an indicator of the basal Wenlock centrifugus Biozone. Exhaustive collecting has failed to confirm the presence of early Wenlock taxa and favours a radically new interpretation of the basal Builth Mudstones Formation contact and adjacent stratigraphy. New dates and detailed section logging demonstrate the presence of a major synsedimentary slide complex that severely disrupted and locally removed much of the Telychian and earlymid Wenlock parts of the succession (Davies et al. 2010, 2011). Graptolites of the riccartonensis Biozone have been obtained from rafts of Builth Mudstone Formation within this slide-disturbed succession [5e, $6 \mathrm{~m}]$. The undisturbed Wenlock laminites that drape the upper surface of this slide-affected zone consistently yield dubius Biozone graptolites (sensu Zalasiewicz \& Williams 1999; Fig. 14), such as to the southwest of Coed Shon [1d] and several localities to the north [e.g. 6o] (Fig. 4D). The products of a subsequent, late Wenlock phase of slumping and sliding succeed and locally truncate this drape succession (Fig. 3). Details of the nature and significance of these discoveries will be presented elsewhere.

\section{Stratigraphical synthesis}

A number of key stratigraphical conclusions emerge from this new architectural analysis of the Type Llandovery succession (Fig. 19):

(1) Key sedimentary and faunal changes that signalled the end of the Late Ordovician glacial maximum and the onset of the Llandovery sedimentary regime in its type area were initiated prior to the FAD of persculptus Biozone graptolites in Wales.

(2) Upper Hirnantian to Aeronian strata comprise a series of prograde sequences separated by flooding surfaces and correlative unconformities. Each prograde was likely a far field response to South Polar glacial advance and global lowering of sea level.

(3) Late Hirnantian, Rhuddanian and Aeronian sequences can be grouped into three composite (or higher order) sequences which reached their progradational acme during the acinaces, lower convolutus and upper sedgwickii-halli graptolite biozones. Significant lower order progradations also occurred during the revolutus, triangulatus and both the middle and upper convolutus biozones. Two late Hirnantian sequences record the impact of the initial global rises in sea level that followed the Late Ordovician glacial maximum.

(4) Following a post-glacial maximum persculptus Biozone highstand, the succession of Llandovery flooding surfaces record glacioeustatic transgressions that peaked during the revolutus, middle convolutus and lower sedgwickii biozones; significant secondary 


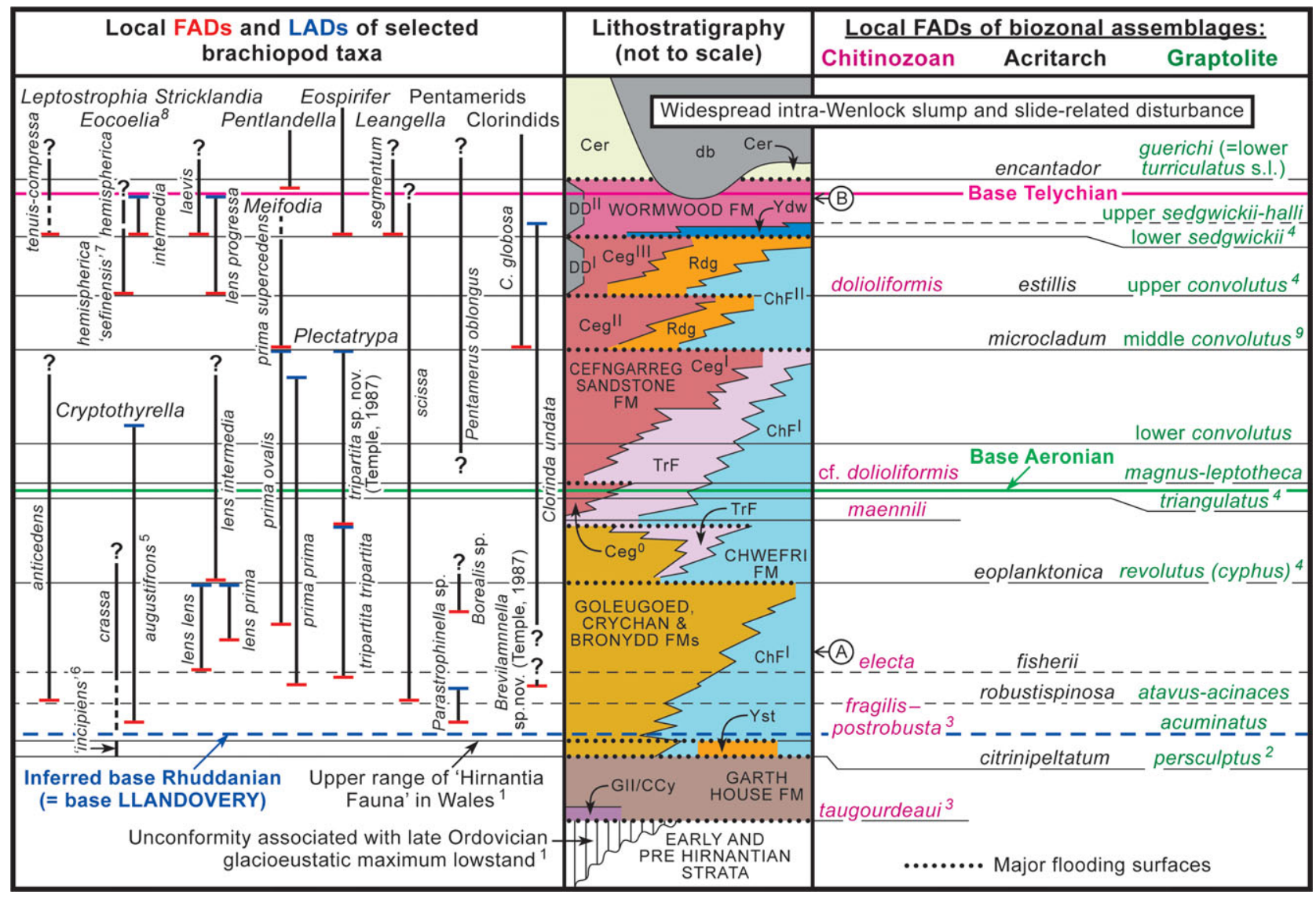

Figure 19. (Colour online) Stratigraphical synthesis of the Type Llandovery succession focusing on the late Hirnantian to Aeronian; see Figure 2 for key lithostratigraphical symbols and Appendix 1 for biostratigraphical data and sources. Relative position of Derwyddon Formation (DD) in central column is shown schematically; FADs and LADs of key brachiopod taxa based largely on Williams (1951), Cocks et al. (1984) and Temple (1987); dashed tie lines denote uncertainty. N.B. FADs of biozonal assemblages shown as coincident with a flooding surface should be taken to imply that diagnostic taxa have been recovered from strata closely overlying this level and that taxa confined to the preceding biozone have not been found above it; in the generalized context of this figure the coincidence of such tie lines should be viewed as approximate. A - Icriodella discreta-I. deflecta Assemblage Biozone conodonts; B - FAD avitus-dilatus Biozone spores. Notes: 1 - see Davies et al. (2009); 2 - level equivalent to FAD of persculptus Biozone graptolites in Wales; 3 - see Section 4.e; 4 - position significantly revised relative to Cocks et al. (1984); 5 - referred to the genus Hyattidina? by Temple (1987); $6-C r$. incipiens is recognized as an early form of Cr. crassa in the Haverfordwest area (Temple, 1987); 7 - 'more primitive' morph (Zeigler, 1966); $8-$ E. curtisi is present in slide-affected strata and a form transitional with E. sulcata is reported from the top of the Cerig Formation in the south Llandovery area (see Section 4.b); 9 - used informally in the Llandovery area; acuminatus Biozone ascensus-accuminatus Biozone of Zalasiewicz et al. (2009).

events are linked to FADs of revolutus and upper convolutus graptolite biozonal assemblages.

(5) Significant deepening at the base of the Cerig Formation coincides with the FAD of guerichi Biozone graptolites, but in this case the impact of any eustatic sea level rise was possibly enhanced or overridden by the growing influence in Wales of Telychian tectonism.

(6) The main Crychan-Goleugoed progradation, widely cited as providing evidence of increased sediment input to the Welsh Basin during the revolutus Biozone highstand, reached its acme during the acinaces Biozone; the Crychan-Goleugoed system underwent a marked and consistent contraction during the subsequent revolutus Biozone deepening.

(7) Transitions within the Stricklandia lens and newly plotted Meifodia prima and Plectatrypa tripartita brachiopod lineages can be calibrated with the
FADs of graptolite assemblages and used for local correlation, as can the FADs of species of Clorinda, Cryptothyrella, Leangella and Leptostrophia, and the generic transition from Borealis to Pentamerus.

(8) Cross-correlation of macro- and microfossil biozonal schemes reveals that important faunal turnovers can be linked to major flooding events, notably during the persculptus-acuminatus biozones, coinciding with the FAD of revolutus Biozone graptolites, and in the middle and upper convolutus Biozone. Significant faunal changes also occurred during the sedgwickii Biozone interval, and new microflora entered alongside guerichi Biozone graptolites. However, neither of the two stage GSSPs defined in the Type Llandovery area appear to coincide with faunal events currently viewed as key for international correlation.

(9) The FAD of lower sedgwickii Biozone assemblages is revised upwards to the base of a 
revised Wormwood Formation (Ydw Member); much of the strata equivalent to units $\mathrm{C}_{1-3}$ of Jones (1925) are now recognized as convolutus Biozone in age.

(10) Though confirmed as a sedgwickii Biozone event, it is the marked overstep observed at the base of the Wormwood Formation and correlative parts of the Derwyddon Formation (DD ${ }^{\mathrm{II}}$ ) that represents the 'Upper Llandovery' unconformity of earlier workers (Fig. 17).

(11) Key elements of the Eocoelia and Stricklandia brachiopod lineages are all present in the Wormwood Formation. E. hemispherica and S. lens progressa are also present in strata below the Wormwood Formation and pre-date the Ydw Member FAD of sedgwickii Biozone graptolites; E. intermedia and the genus Eospirifer both have FADs within the Ydw Member and $S$. laevis and the genus Pentlandella also enter in the formation. The FADs of all these taxa predate the Cerig Formation FAD of guerichi Biozone graptolites.

(12) No post-guerichi Biozone Llandovery graptolites have been recovered from the type area. Younger Llandovery and basal Wenlock assemblages are present in the nearby Garth area. The earliest Wenlock graptolites in the Llandovery area, of riccartonensis Biozone age, were obtained from slide-disturbed strata. The overlying drape succession yields dubius Biozone graptolites.

(13) New and re-evaluated acritarch data show that the fisherii Biozone is pre-revolutus Biozone in age; the eoplanktonica Biozone is in part Rhuddanian; and that the microcladum Biozone entirely and the estillis Biozone partly pre-date the FAD of sedgwickii Biozone graptolites. Acritarch FADs above the earliest Cefngarreg Sandstone prograde $\left(\mathrm{Ceg}^{0}\right)$ and overlying the base of the Wormwood Formation may provide the basis for the division of the eoplanktonica and estillis biozones, respectively. Gracilisphaeridium encantador Biozone acritarchs, recorded for the first time in the Llandovery area, enter with guerichi Biozone graptolites at the base of the Cerig Formation.

(14) Hirnantian chitinozoans suggestive of the taugourdeaui Biozone are present in the Garth House Formation. The early Llandovery fragilis and postrobusta biozones have not been proven, but assemblages of the succeeding electa, maennilli and dolioliformis biozones are recognized and the local FADs of precursor species, notably E. cf. dolioliformis, allow further refinement. Critically, Wenlock margaritana Biozone assemblages have been obtained from strata previously believed to be Telychian in age.

(15) Recognition of a series of major mid Wenlock, slide-related deformation features and of significant stratal loss affecting the post-Wormwood Formation succession precludes accurate interpretation of this portion of the Type Llandovery stratigraphy and undermines the relevance of the macro- and microfaunal criteria cited by Cocks et al. (1984) as critical in the definition and selection of the Telychian Stage GSSP.

\section{Conclusions}

These findings have potentially far reaching bio- and chronostratigraphical implications. On the one hand they demonstrate significant shortcomings with both the Aeronian and Telychian GSSPs and the criteria cited at the time of their selection as critical for international correlation. The uncritical use of key biostratigraphical markers within the Stricklandia and Eocoelia brachiopod lineages is also questioned. The ranges of published acritarch biozone assemblages are thoroughly revised and erection of the monospinosa acritarch Biozone within the Cerig Formation by Hill \& Dorning (1984) is shown to be untenable. Stratal loss is also shown to be far more widespread than previously envisaged in both the proximal (non-sequences) and distal (slumping) portions of the sedimentary system. Moreover, widespread disturbance of upper parts of the Llandovery succession took place during emplacement of a regional-scale intra-Wenlock slide complex.

On the other hand, the new data and synthesis reinforce the Llandovery area as one of the best studied early Silurian successions in the world. The establishment of a eustatically driven RhuddanianAeronian sequence stratigraphy, calibrated against a much more robust graptolite dataset, provides the basis for a global scheme defined at both composite (higher) and lower order sequence levels. In addition to the qualified use of Stricklandia and Eocoelia as tools for correlation, lineages of the brachiopods Meifodia, Plectatrypa and other genera are shown to have local potential. The faunal changes that occurred in the wake of the Late Ordovician glacial maximum, and the marked micro- and macrofaunal renewals associated with the FADs of the revolutus, middle and upper convolutus, lower sedgwickii and guerichi graptolite biozone assemblages all offer potential for international testing to support any future revision of the stage boundaries and their defining criteria; and a newly applied chitinozoan biozonation is now available to aid this process (Fig. 19).

It is not for this paper unilaterally to abandon the current stage GSSPs in the Llandovery area or to propose alternative sites and defining criteria. However, candidate sections exist locally that would continue broadly to reflect the concepts approved of in the selection of the current sites, as well as the historical importance and improved understanding of the succession, to which this study contributes. Repositioning of the Aeronian GSSP to a level nearer the FAD of triangulatus Biozone graptolites in the Trefawr track may be practicable. The base of the Telychian Stage should continue to reflect the faunal flux associated with the Wormwood Formation. The FADs of lower sedgwickii Biozone graptolites and of genera/species of brachiopods and acritarchs in the Ydw Member, or one of the other key faunal and/or 
floral events within the Wormwood Formation (Fig. 19), are obvious levels to consider. The level close to the base of the Cerig Formation in the Derwyddon area at which guerichi Biozone graptolites and encantador Biozone acritarchs first appear also has merit.

Moreover, the deficiencies of the Llandovery type area are compensated for when it is viewed in a regional context (Fig. 1). The adjacent, richly graptolitic Welsh Basin succession allows the recognition of all the standard Llandovery graptolite biozones and, notably in the Wye valley near Rhayader, includes the type localities for many (e.g. Lapworth, 1900; Wood, 1906; Loydell, 1991, 1992; Zalasiewicz, 1994, 1996; Zalasiewicz \& Tunnicliff, 1994; Davies et al. 1997; Zalasiewicz et al. 2009). Jones (1909) worked on the famous Rheidol Gorge succession prior to his study of the Llandovery area and subsequent examination has updated his sequence of Rhuddanian and Aeronian graptolite biozones (Sudbury, 1958; Cave \& Hains, 1986). There, the triangulatus Biozone has been recognized in a fully exposed, continuously graptolitic section (Cullum \& Loydell, 2011). Recent work on the basin centre succession has allowed subdivision of the turriculatus s.l., crispus and griestoniensis biozones (e.g. Zalasiewicz, 1990; Loydell, 1992); and a detailed latest Llandovery and earliest Wenlock graptolite biozonation has been established in the Afon (River) Banwy in the east of the basin (Loydell \& Cave, 1996). It seems entirely appropriate for the Type Llandovery concept to be broadened to encompass these adjacent stratigraphies and, potentially, for its stage stratotypes to be redefined and relocated in these strata.

Acknowledgements. Discussions with Rob Hillier (National Museum of Wales) with regard to facies models and the valued input of David Schofield and David Wilson, both of BGS, during the field investigations and drafting of this paper are gratefully acknowledged. Several of the classic sections, now Geological Conservation Review (GCR) sites, in the Type Llandovery area were specially cleared in 2009 by the Countryside Council for Wales (CCW). Sid Howells and Gareth Owen of CCW and the staff of the Forestry Commission Llandovery Office are thanked for their hard work in the clearing operations. Local landowners are warmly thanked for allowing repeated access to sections on their land and Mr Marcus Lampard of Mandinam, Llangadog for extending a key section on his property. This paper has benefited from reviews by Howard Armstrong, Mike Melchin, Phil Stone and Nigel Woodcock. The superb drafting skills of Antony Smith and Ian Gully of Aberystwyth University are also gratefully acknowledged. This research was supported by the BGS University Funding Initiative (BUFI) Contract No. P093; T. Vandenbroucke also thanks FWO-Flanders and the CNRS (France) for funding support. J. R. Davies and S. G. Molyneux publish with permission of the Executive Director of BGS. This work is a contribution to IGCP 591.

\section{References}

ALDRIDGE, R. J. 2000. The Llandovery Series. In British Silurian Stratigraphy (eds R. J. Aldridge, D. J. Siveter,
D. J. Siveter, P. D. Lane, D. G. Palmer \& N. H. Woodcock), pp. 69-180. Geological Conservation Review Series, no. 19. Joint Nature Conservation Committee.

BAARLI, B. G. 1986. A biometric re-evaluation of the Silurian brachiopod lineage Stricklandia lens/S. laevis. Palaeontology 29, 187-205.

BANN, K. L. \& FIELDING, C. R. 2004. An integrated ichnological and sedimentological comparison of nondeltaic shoreface and subaqueous delta deposits in Permian reservoir units of Australia. In The Application of Ichnology to Palaeoenvironmental and Stratigraphic Analysis (ed. D. McIlroy), pp. 273-310. Geological Society of London, Special Publication no. 228.

Barclay, W. J., Davies, J. R., Humpage, A. J., Waters, R. A., Wilby, P. R., Williams, M. \& Wilson, D. 2005. Geology of the Brecon District - a Brief Explanation of the Geological Map. Sheet Explanation of the British Geological Survey. 1:50 000 Sheet 213 Brecon (England and Wales). Keyworth, Nottingham: British Geological Survey, $38 \mathrm{pp}$.

BASSETT, M. G. 1989. Brachiopods. In A Global Standard for the Silurian System (eds C. H. Holland \& M. G. Bassett), pp. 232-42. National Museum of Wales, Geological Series no. 9.

BASSETT, D. A. 1991. Roderick Murchison's The Silurian System: a sesquicentennial tribute. In The Murchison Symposium: Proceedings of an International Conference on the Silurian System (eds M. G. Bassett, P. D. Lane \& D. Edwards), pp. 7-90. Special Papers in Palaeontology no. 44. The Palaeontological Association.

BAssetT, M. G. \& RonG, J. U. 2002. Brachiopods. In Telychian Rocks of the British Isles and China (Silurian, Llandovery Series): An Experiment to Test Precision in Stratigraphy (eds C. H. Holland \& M. G. Bassett), pp. 124-36. National Museum of Wales, Cardiff, Geological Series no. 21.

Blackett, E., Page, A., Zalasiewicz, J. A., Williams, M., RickARDS, R. B. \& DAVIES, J. R. 2009. A refined graptolite biostratigraphy for the late Ordovician-early Silurian of central Wales. Lethaia 43, 83-96.

British GeOlOGICAL SURVEY. 2005a. Builth Wells. England and Wales Sheet 196. Solid Geology, 1:50 000. Keyworth, Nottingham: British Geological Survey.

British GeOlogical Survey. 2005b. Brecon. England and Wales Sheet 213. Bedrock and Superficial Deposits, 1:50 000. Keyworth, Nottingham: British Geological Survey.

British GeOlogical SuRVeY. 2008. Llandovery. England and Wales Sheet 212. Bedrock and Superficial Deposits, 1:50 000. Keyworth, Nottingham: British Geological Survey.

BuRgESS, N. D. 1991. Silurian cryptospores and miospores from the type Llandovery area, south-west Wales. Palaeontology 34, 575-99.

CAPUTO, M. V. 1998. Ordovician-Silurian glaciations and global sea-level changes. In Silurian Cycles: Linkages of Dynamic Stratigraphy with Atmospheric, Oceanic and Tectonic Changes (eds E. Landing \& M. E. Johnson), pp. 15-25. New York State Museum Bulletin no. 491 .

CAVE, R. \& Hains, B. A. 1986. Geology of the Country Between Aberystwyth and Machynlleth. Memoir of the British Geological Survey, Sheet 163 (England and Wales). Keyworth, Nottingham: British Geological Survey, $148 \mathrm{pp}$.

CocKS, L. R. M. 1968. Some strophomenacean brachiopods from the British Lower Silurian. Bulletin of the British Museum (Natural History), Geology Series 15, 283-324. 
Cocks, L. R. M. 1970. Silurian brachiopods of the Superfamily Plectambonitacea. Bulletin of the British Museum (Natural History), Geology Series 19, 139203.

Cocks, L. R. M. 1971. The Llandovery District. In Geological Excursions in South Wales and the Forest of Dean (eds D. A. Bassett \& M. G. Bassett), pp. 15561. The Geologists' Association of South Wales (South Wales Group).

Cocks, L. R. M. 1978. A review of British Lower Palaeozoic brachiopods, including a synoptic revision of Davidson's monograph. Monograph of the Palaeontographical Society, London 131, 1-256.

Cocks, L. R. M. 1989. The Llandovery Series in the Llandovery area. In A Global Standard for the Silurian System (eds C. H. Holland \& M. G. Bassett), pp. 36-50. National Museum of Wales, Cardiff, Geological Series no. 9 .

Cocks, L. R. M., Forty, R. A. \& Rushton, A. W. A. 2010. Correlation for the Lower Palaeozoic. Geological Magazine 147, 171-80.

Cocks, L. R. M., Holland, C. H., Rickards, R. B. \& STRACHAN, I. 1971. A correlation of Silurian rocks in the British Isles. Journal of the Geological Society, London 127, 103-36.

Cocks, L. R. M., Toghill, P. \& Ziegler, A. M. 1970. Stage names within the Llandovery Series. Geological Magazine 107, 79-87.

Cocks, L. R. M., WoOdCOCK, N. H., Rickards, R. B., TEMPle, J. T. \& LANE, P. D. 1984. The Llandovery Series of the type area. Bulletin of the British Museum (Natural History), Geology Series 38, 13182.

Cramer, F. H. 1968. Palynologic microfossils of the Middle Silurian Maplewood Shale in New York. Revue de Micropaléontologie 11(2), 61-70, pl. 1.

CRAMER, F. H. 1970. Distribution of selected Silurian acritarchs; an account of the palynostratigraphy and paleogeography of selected Silurian acritarch taxa. Revista Española de Micropaleontología (número extraordinario), 1-203, pls I-XXIII.

Cramer, F. H. \& DíEz DE CRAMER, M. DEL C. R. 1972. North American Silurian palynofacies and their spatial arrangement: acritarchs. Palaeontographica Abteilung $B$ 138, 107-80, pls 31-6.

Cramer, B. D., Loydell, D. K., SAmtleben, C., Munnecke, A., Kaljo, D., Männik, P., Martma, T., Jeppsson, L., KlefFner, M. A., BARrick, J. E., Johnson, C. A., EMSBO, P., JOACHIMSKI, M. M., BickerT, T. \&. SALtzMAN, M. R. 2010. Testing the limits of Paleozoic chronostratigraphic correlation via highresolution $(<500 \mathrm{kyr})$ integrated conodont, graptolite, and carbon isotope $\left(\delta^{13} \mathrm{C}_{\text {carb }}\right)$ biochemostratigraphy across the Llandovery-Wenlock (Silurian) boundary: is a unified Phanerozoic timescale achievable? Geological Society of America Bulletin 122, 1700-16.

Cullum, A. A. \& Loydell, D. K. 2011. The Rhuddanian/Aeronian transition in the Rheidol Gorge, mid Wales. Proceedings of the Yorkshire Geological Society 58, 261-66.

DaVies, J. R., Fletcher, C. J. N., WATERS, R. A., Wilson, D., Woodhall, D. G. \& Zalasiewicz, J. A.1997. Geology of the Country Around Llanilar and Rhayader. Memoir of the British Geological Survey, Sheets 178 and 179 (England and Wales). Keyworth, Nottingham: British Geological Survey, 267 pp.

Davies, J. R., MolyneuX, S. G., Vandenbroucke, T. R. A., Verniers, J., WATERs, R. A., Williams, M. \&
Zalasiewicz, J. A. 2011. Pre-conference field trip to the Type Llandovery area. In Siluria Revisited: A Field Guide (ed. D. C. Ray), pp. 29-72. International Subcommission on Silurian Stratigraphy, Field Meeting, 2011.

DAVIES, J. R. \& WATERS, R. A. 1995. The Caban Conglomerate and Ystrad Meurig Grits Formation - nested channels and lobe switching on a mud-dominated latest Ashgill to Llandovery slope apron, Welsh Basin, UK. In Atlas of Deep Water Environments: Architectural Style in Turbidite Systems (eds K. T Pickering, R. N. Hiscott, N. H. Kenyon, F. Ricci Lucci \& R. D. A. Smith), pp. 184-93. London: Chapman \& Hall.

Davies, J. R., Waters, R. A. \& Copus, J. 1999. Facies and geometry of deep-water turbidite systems in the Lower Palaeozoic Welsh Basin. AAPG International Conference (Birmingham), Field Trip 2: 8-11 September. British Geological Survey Technical Report (WA/00/095).

Davies, J. R., WATERS, R. A., Williams, M., Wilson, D., SChofield, D. I. \& Zalasiewicz, J. A. 2009. Sedimentary and faunal events revealed by a revised correlation of post-glacial Hirnantian (late Ordovician) strata in the Welsh basin, U.K. Geological Journal 44, $322-40$.

DAVIES, J. R., WATERS, R. A., ZALASIEWICZ, J. A. MolyneuX, S. G., VAndenbroucke, T. R. A. \& WiLliaMS, M. 2010. A revised sedimentary and biostratigraphical architecture for the type Llandovery and Garth areas, central Wales: a field guide. British Geological Survey Open Report, OR/10/037.

De Permentier, J. \& Verniers, J. 2002. Chitinozoans from the global stratigraphical sections and points (GSSP) of the bases of the Aeronian and the Telychian (Llandovery) in Wales, U.K. In Palaeozoic Palynology in the Third Millenium: New Directions in Acritarch, Chitinozoan and Miospore Research, p. 16. Abstracts volume, International Meeting and Workshop of the International Commission of the Palaeozoic Microflora, Lille, France, 5-7 September 2002.

DEUNFF, J. \& EVITT, W. R. 1968. Tunisphaeridium, a new acritarch genus from the Silurian and Devonian. Stanford University Publications, Geological Sciences 12(1), 1-13, pl. 1.

Dias-Martinez, E. \& GRAhN, Y. 2007. Early Silurian glaciation along the western margin of Gondwana (Peru, Bolivia and northern Argentina): palaeogeography and geodynamic setting. Palaeogeography, Palaeoclimatology, Palaeoecology 252, 62-81.

DoRNING, K. J. \& BELL, D. G. 1987. The Silurian carbonate shelf microflora: acritarch distribution in the Much Wenlock Limestone Formation. In Micropalaeontology of Carbonate Environments (ed. M. B. Hart), pp. 26687. Chichester: Ellis Horwood.

Doyle, E. N., Hoey, A. N. \& Harper, D. A. T. 1994. The rhynchonellide brachiopod Eocoelia from the upper Llandovery of Ireland and Scotland. Palaeontology 34, 439-54.

Duval, B., Cramez, C. \& VaIL, P. R. 1992. Types and hierarchy of stratigraphic cycles. In Sequence Stratigraphy of European Basins, pp. 44-5. Abstracts volume, Centre National de la Recherche Scientifique \& Institut Francais du Pétrole, Dijon, 1992.

Eisenack, A., Cramer, F. H. \& DíEZ, M. DEL C. R. 1973. Katalog der Fossilen Dinoflagellaten, Hystrichosphären und Verwandten Mikrofossilien. Band III Acritarcha 1. Teil. Stuttgart: E. Schweizerbart'sche Verlagsbuchhandlung, $1104 \mathrm{pp}$. 
Eisenack, A., Cramer, F. H. \& DíEz, M. Del C. R. 1976. Katalog der Fossilen Dinoflagellaten, Hystrichosphären und Verwandten Mikrofossilien. Band IV Acritarcha 2. Teil. Stuttgart: E. Schweizertbart'sche Verlagsbuchhandlung, $863 \mathrm{pp}$.

FloYD, J. D. \& Williams, M. 2003. A revised lithostratigraphy for the Silurian of the Girvan district. Transactions of the Royal Society of Edinburgh: Earth Sciences 93, 383-92.

GAWTHORPE, R. L., HALl, M., SHARP, I. \& DREYER, T. 2000. Tectonically enhanced forced regressions: examples from growth folds in extensional and compressional settings, the Miocene of the Suez and the Eocene of the Pyrenees. In Sedimentary Responses to Forced Regressions (eds D. Hunt \& R. L. Gawthorpe), pp. $177-$ 91 Geological Society of London, Special Publication no. 172 .

HAQ, B. U. \& SchutTer, S. R. 2008. A chronology of Paleozoic sea-level change. Science 322, 64-8.

HILL, P. J. \& DoRNING, K. J. 1984. Appendix 1: Acritarchs. In The Llandovery Series of the Type Area (L. R. M. Cocks, N. H. Woodcock, R. B. Rickards, J. T. Temple \& P. D. Lane), pp. 174-76. Bulletin of the British Museum (Natural History), Geology Series 38, 13182.

Holland, C. H. 1989. Principles, history and classification. In A Global Standard for the Silurian System (eds C. H. Holland \& M. G. Bassett), pp. 7-26. National Museum of Wales, Cardiff, Geological Series no. 9.

Holland, C. H. \& BassetT, M. G. 1988. Discussion on biostratigraphical correlation and the stages of the Llandovery. Journal of the Geological Society, London 145, 881-2.

Holland, C. H. \& BASSETT, M. G. 2002. Telychian Rocks of the British Isles and China (Silurian, Llandovery Series): An Experiment to Test Precision in Stratigraphy. National Museum of Wales, Cardiff, Geological Series, no. 21 .

Hurst, J. M., HANCOCK, N. J. \& MCKerRow, W. S. 1978. Wenlock stratigraphy and palaeogeography of Wales and the Welsh borderland. Proceedings of the Geologists' Association 89, 197-226.

JIN, J. \& COPPER, P. 1999. The deep-water brachiopod Dicoelosia King, 1850, from the early Silurian tropical carbonate shelf of Anticosti Island, Eastern Canada. Journal of Paleontology 73, 1042-55.

JoHnsON, M. E. 2006. Relationship of Silurian sea-level fluctuations to oceanic episodes and events. $G F F \mathbf{1 2 8}$, $115-21$.

JoHnsOn, M. E. 2010. Tracking Silurian eustasy: alignment of empirical evidence or pursuit of deductive reasoning? Palaeogeography, Palaeoclimatology, Palaeoecology 296, 276-84.

Johnson, M. E., KALJO, D. K. \& RonG, J.-Y. 1991. Silurian eustasy. In The Murchison Symposium: Proceedings of an International Conference on the Silurian System (eds M. G. Bassett, P. D. Lane \& D. Edwards), pp. 145-63. Special Papers in Palaeontology no. 44. The Palaeontological Association.

Johnson, M. E., RONG, J. U. \& YANG, X. C. 1985. Intercontinental correlation by sea-level events in the early Silurian of North America and China (Yangtze platform). Geological Society of America Bulletin 96, 1384-97.

JONES, O. T. 1909. The Hartfell-Valentian succession in the district around Plynlimon and Pont Erwyd (north Cardiganshire). Quarterly Journal of the Geological Society of London 65, 463-537.
Jones, O. T. 1921. The Valentian Series. Quarterly Journal of the Geological Society of London 77, 14474.

JONES, O. T. 1925. The geology of the Llandovery district. Part I: the southern area. Quarterly Journal of the Geological Society of London 81, 344-88.

JONES, O. T. 1928. Plectambonites and some allied genera. Memoir of the Geological Survey, UK, London, (Palaeontology) 1, 367-527.

JONES, O. T. 1949. The geology of the Llandovery district. Part II: the northern area. Quarterly Journal of the Geological Society of London 105, 43-64.

JoneS, O. T. \& Williams, A. 1949. Appendix - Note on the Llandovery rocks on the River Sefin, near Llangadock. Quarterly Journal of the Geological Society of London 105, 61-3.

LAPWORTH, H. 1900. The Silurian sequence of Rhayader. Quarterly Journal of the Geological Society of London 56, 67-137.

LISTER, T. R. 1970. The Acritarchs and Chitinozoa from the Wenlock and Ludlow Series of the Ludlow and Millichope areas, Shropshire. Monograph of the Palaeontographical Society, London 124, 1-100, pls 1-13.

LOYDELL, D. K. 1991. The biostratigraphy and formational relationships of the upper Aeronian and lower Telychian (Llandovery, Silurian) formations of western midWales. Geological Journal 26, 209-44.

LOYDELL, D. K. 1992. Upper Aeronian and Lower Telychian (Llandovery) graptolites from western mid-Wales. Part 1. Monograph of the Palaeontographical Society, London 146, 1-55.

LOYDELL, D. K. 1998. Early Silurian sea-level changes. Geological Magazine 135, 447-71.

LOYDELL, D. K. 2007. Early Silurian positive $\delta^{13} \mathrm{C}$ excursions and their relationship to glaciations, sea level changes and extinction events. Geological Journal 42, 53146.

LOYDELL, D. K. 2012. Graptolite biozone correlation charts. Geological Magazine 149, 124-32.

LOYDELL, D. K. \& CAVE, R. 1996. The Llandovery-Wenlock boundary and related stratigraphy in eastern mid Wales with special reference to the Banwy River section. Newsletters on Stratigraphy 34, 39-64.

Martin, M. A. \& Pollard, J. E. 1996. The role of trace fossil (ichnofabric) analysis in the development of depositional models for the Upper Jurassic Fulmar Formation of the Kittiwake Field (Quadrant 21 UKCS). In Geology of the Humber Group: Central Graben and Moray Firth UKCS (eds A. Hurst, H. Johnson, S. D. Burley, A. C. Canham \& D. S. Mackertich), pp. 16383. Geological Society of London, Special Publication no. 114.

Melchin, M. J., CoOper, R. A. \& SAdLeR, P. M. 2004. The Silurian Period. In A Geological Time Scale 2004 (eds F. M. Gradstein, J. G. Ogg \& A. G. Smith), pp. 188-201. Cambridge: Cambridge University Press.

MolyneuX, S. G. 2003. Palynological report on samples from Crychan Forest. British Geological Survey Internal Report, IR/03/054R.

MuLLINS, G. L. \& LOYDELL, D. K. 2002. Integrated lower Silurian chitinozoan and graptolite biostratigraphy of Buttington Brick Pit, Wales. Geological Magazine 139, 89-96.

Munnecke, A., Calner, M., Harper, D. A. T. \& SERVAIS, T. 2010. Ordovician and Silurian sea-water chemistry, sea level and climate: a synopsis. Palaeogeography, Palaeoclimatology, Palaeoecology 296, 389413. 
Murchison, R. I. 1867. Siluria, 4th ed. John Murray.

Page, A. A., Zalasiewicz, J. A., Williams, M. \& Popov, L. E. 2007. Were transgressive black shales a negative feedback modulating glacioeustasy during the Early Palaeozoic Icehouse? In Deep Time Perspectives on Climate Change: Marrying the Signal From Computer Models and Biological Proxies (eds M. Williams, A. M. Haywood, F. J. Gregory \& D. N. Schmidt), pp. 123-56. The Micropalaeontological Society Special Publications. London: The Geological Society.

Postma, G. 1990. Depositional architecture and facies of river and fan deltas: a synthesis. In Coarse Grained Deltas (eds A. Colella \& D. B. Prior), pp. 13-27. Special Publication of the International Association of Sedimentologists, no. 10.

REINECK, H.-E. \& Singh, I. B. 1975. Depositional Sedimentary Environments - With Reference to Terrigenous Clastics. Berlin: Springer-Verlag, 439 pp.

Ross, C. A. \& Ross, R. P. 1996. Silurian sea level fluctuations. In Paleozoic Sequence Stratigraphy: Views from the North American Craton (eds B. J. Witzke, G. A. Ludvigson \& J. Day), pp. 187-92. Geological Society of America, Special Paper no. 306.

Schofield, D. I., Davies, J. R., JoNes, N. S., Leslie, A. B., Waters, R. A., Williams, M., Wilson, D., Venus, J. \& Hillier, R. D. 2009b. Geology of the Llandovery District - A Brief Explanation of the Geological Map. Sheet Explanation of the British Geological Survey. 1:50 000 Sheet 212 Llandovery (England and Wales). Keyworth, Nottingham: British Geological Survey.

Schofield, D. I., DAVIES, J. R., WATERS, R. A., Wilby, P. R., Williams, M. \& Wilson, D. 2004. Geology of the Builth Wells District - A Brief Explanation of the Geological Map. Sheet Explanation of the British Geological Survey. 1:50 000 Sheet 196 Builth Wells (England and Wales). Keyworth, Nottingham: British Geological Survey.

SChOFIELD, D. I., DAVIES, J. R., WATERS, R. A., Williams, M \& WiLSON, D. 2009a. A new Early Silurian turbidite system in Central Wales: insights into eustatic and tectonic controls on deposition in the southern Welsh basin. Geological Magazine 146, 121-32.

SIVETER, D. J., OwENS, R. M. \& THOMAS, A. T. 1989. Silurian field excursions: a geotraverse across Wales and the Welsh Borderland. National Museum of Wales, Cardiff, Geological Series no. 10.

SMELROR, M. 1987. Early Silurian acritarchs and prasinophycean algae from the Ringerike District, Oslo Region (Norway). Review of Palaeobotany and Palynology 52, 137-59.

SudBuRY, M. 1958. Triangulate monograptids from the Monograptus gregarious Zone (lower Llandovery) of the Rheidol gorge (Cardiganshire). Philosophical Transactions of the Royal Society of London B241, 485555.

TAYlOR, A. M. \& GoldRING, R. 1993. Description and analysis of bioturbation and ichnofabric. Journal of the Geological Society, London 159, 141-48.

TEMPLE, J. T. 1987. Early Llandovery brachiopods of Wales. Monograph of the Palaeontographical Society, London 139, 1-137.

TEMPLE, J. T. 1988. Biostratigraphical correlation and stages of the Llandovery. Journal of the Geological Society, London 145, 875-9.

VANDENBRoucKe, T. R. A. 2008. An Upper Ordovician chitinozoan biozonation in British Avalonia (England \& Wales). Lethaia 41, 275-94.
Vandenbroucke, T. R. A., Hennissen, J., Zalasiewicz, J. A. \& VERniers, J. 2008. New chitinozoans from the historical type area of the Hirnantian and additional key sections in the Wye valley, Wales, UK. Geological Journal 43, 397-414.

Van Wagoner, J. C., Mitchum, R. M., Campion, K. M., \& Rahmanian, V. D. 1990. Siliclastic Sequence Stratigraphy in Well Logs, Cores and Outcrops: Concepts for High-resolution Correlation of Time and Facies. Association of American Petroleum Geologists Methods in Exploration Series no. 7.

VERNIERS, J. 1999. Calibration of Chitinozoa versus graptolite biozonation in the Wenlock of Builth Wells district (Wales, UK), compared with other areas in Avalonia and Baltica. Bollettino della Societa Paleontologica Italiana 38, 1-22.

Verniers, J., Nestor, V., PARis, F., DufKa, P., Sutherland, S. \& VAN Grootel, G. 1995. A global Chitinozoa biozonation for the Silurian. Geological Magazine 132, 651-66.

WeISE, B. R. 1980. Wave-Dominated Delta Systems of the Upper Cretaceous San Miguel Formation, Maverick Basin, South Texas. Report of Investigations, 107. Austin, Texas: Bureau of Economic Geology.

Wescott, W. A. \& ETherRidge, F. G. 1990. Fan deltas alluvial fans in coastal settings. In Alluvial Fans: A Field Approach (eds A. H. Rachocki \& M. Church), pp. 195 211. Chichester: John Wiley \& Sons.

WiLliaMS, A. 1951. Llandovery brachiopods from Wales with special reference to the Llandovery district. Quarterly Journal of the Geological Society of London 107, 85-136.

WiLliams, A. 1953. The geology of the Llandeilo district, Carmarthenshire. Quarterly Journal of the Geological Society of London 108, 177-205.

Williams, S. H. \& INGHAM, J. K. 1989. The OrdovicianSilurian boundary stratotype at Dob's Lin, southern Scotland. In A Global Standard for the Silurian System (eds C. H. Holland, \& M. G. Bassett), pp. 27-35. National Museum of Wales, Cardiff, Geological Series no. 9.

WooD, E. M. R. 1906. On the Tarannon Series of Tarannon. Quarterly Journal of the Geological Society of London 62, 644-701.

WooD, G. D. 1996. Biostratigraphic, paleoecologic and biologic significance of the Silurian (Llandovery) acritarch Beromia rexroadii gen. emend. et sp. nov., Mid-continent and Eastern United States. Palynology 20, 177-89.

WoodCOCK, N. H. 1987. Structural geology of the Llandovery Series in the type area, Dyfed, Wales. Geological Journal 22, 199-209.

Woodcock, N. H., Butler, A. J., DAVIES, J. R. \& WATERS, R. A. 1996. Sequence stratigraphical analysis of late Ordovician and early Silurian depositional systems in the Welsh basin: a critical assessment. In Sequence Stratigraphy in British Geology (eds S. P. Hesselbo \& D. N. Parkinson), pp. 197-208. Geological Society of London, Special Publication no. 103.

Woodcock, N. H. \& GIBBONS, W. 1988. Is the Welsh Borderland Fault System a terrane boundary? Journal of the Geological Society, London 145, 91523.

Woodcock, N. H. \& Smallwood, S. D. 1987. Late Ordovician shallow marine environments due to glacioeustatic regression: Scrach Formation, mid-Wales. Journal of the Geological Society, London 144, 393400. 
Woodcock, N. H., Soper, N. J. \& Strachan, R. A. 2007. A Rheic cause for the Acadian deformation in Europe. Journal of the Geological Society, London 164, 1023 36.

ZALASIEWICZ, J. A. 1990. Silurian graptolite biostratigraphy in the Welsh Basin. Journal of the Geological Society, London 147, 619-22.

ZALASIEWICZ, J. A. 1994. Middle to late Telychian (Silurian:Llandovery) graptolite assemblages of central Wales. Palaeontology 37, 375-96.

ZalasiewICZ, J. A. 1996. Aeronian (Silurian:Llandovery) graptolite assemblages from central Wales. Geologica et Palaeontologica 30, 301-14.

Zalasiewicz, J. A., TaYlor, L., Rushton, A. W. A., LOYDELL, D. K., RickARDS, R. B. \& Williams, M. 2009. Graptolites in British stratigraphy. Geological Magazine 146, 785-850.

ZALASIEWICZ, J. A. \& TUNNICLIFF, S. 1994. Uppermost Ordovician to Lower Silurian graptolite biostratigraphy of the Wye valley, central Wales. Palaeontology 37, 695720.

ZALASIEWICZ, J. A. \& Williams, M. 1999. Graptolite biozonation of the Wenlock Series (Silurian) of the Builth Wells district, central Wales. Geological Magazine 136, 263-83.

ZHANG, S. \& BARNES, C. R. 2002. Late OrdovicianEarly Silurian (Ashgillian-Llandovery) sea level curve derived from conodont community analysis, Anticosti Island, Quebec. Palaeogeography, Palaeoclimatology, Palaeoecology 180, 5-32.

Zhang, S., BARNes, C. R. \& Jowett, D. M. S. 2006. The paradox of the global standard Late OrdovicianEarly Silurian sea level curve: evidence form conodont community analysis from both Canadian Arctic and Appalachian margins. Palaeogeography, Palaeoclimatology, Palaeoecology 236, 246-71.

ZIEGLER, A. M. 1965. Silurian marine communities and their environmental significance. Nature, London 207, 270-2.

ZIEGLER, A. M. 1966. The Silurian brachiopod Eocoelia hemisphaerica (J. de C. Sowerby) and related species. Palaeontology 9, 523-43.

Ziegler, A. M., Cocks, L. R. M. \& BAmbaCH, R. K. 1968. The composition and structure of Silurian marine communities. Lethaia 1, 1-27.

ZIEGLER, A. M., COCKS, L. R. M. \& MCKerRow, W. S. 1968. The Llandovery transgression of the Welsh Borderland. Palaeontology 11, 736-82.
Appendix 1. Key fossil localities and assemblages in the Type Llandovery area

Figures A1-A3 provide details of the key fossil assemblages that underpin the revised sedimentary and biostratigraphical architecture erected for the Type Llandovery succession, and their significance. Traverse line and locality numbers [including those cited in the main text in square brackets] refer to Figures 1 and 11. Localities on each traverse are arranged and numbered in stratigraphical order, oldest to youngest. Localities between traverses have been projected onto the nearest column. All UK National Grid References (NGRs) lie within $100 \mathrm{~km}$ square SN; some NGRs provided by Cocks et al. (1984), Temple (1987) and other authors have been amended where there are clear inaccuracies (e.g. plots off exposure) and these are shown in italics. Six figure NGRs are used for localities cited in older sources where the exact position is uncertain. See Figures 2 and 3 for key to lithostratigraphical symbols. Fossil genera have been updated wherever possible and only where species names have also changed is there additional comment; graptolite nomenclature follows Zalasiewicz et al. (2009); brachiopod nomenclature largely follows Temple (1987). MPA numbers given for acritarch samples refer to the BGS micropalaeontology database; reference numbers for chitinozoan samples refer to University of Ghent databases. Symbols $(*, *,+)$ refer to information in comments column. See main text for discussion of the various macroand microfossil biozonal schemes applied. Notes: The membranifera-Pseudodyadospora sp. B spore Sub-biozone (usage of Burgess, 1991) is abbreviated to membranifera; Temple (1987) refers Cryptothyrella angustifrons to the genus Hyattidina?; Plectatrypa tripartita subsp. nov is of Temple (1987); the long ranging graptolite Raphidograptus toernquisti has been omitted from the list of taxa for localities $4 \mathrm{~h}, 6 \mathrm{c}, 11 \mathrm{~d}$ and $11 \mathrm{~g}$ for brevity.

Key to sources cited in Figures A1-A3: TS - this study; 1 - Williams (1953); 2 -Zeigler (1966); 3 - Williams (1951); 4 - Jones (1925); 5 - Jones \& Williams (1949); 6 - Cocks (1971); 7 - Cocks et al. (1984, including appendix by Hill \& Dorning, 1984); 8 - Temple (1987); 9 - Zalasiewicz et al. (2009); 10 - Davies et al. (2010); 11 - Davies et al. (2009); 12 - Hurst, Hancock \& McKerrow (1978); 13 - Jones (1949); 14 - Cocks (1978); 15 - Molyneux (2003); 16 - De Permentier \& Verniers (2002); 17 - Zalasiewicz \& Williams (1999); 18 - Jones (1928); 19 - Cocks (1970); 20 - BGS collections; 21 - T. J. Challands, unpub. Ph.D. thesis, Univ. Durham, 2008; 22 - Davies et al. (1997); 23 - Burgess (1991). 


\begin{tabular}{|c|c|c|c|c|c|c|c|}
\hline 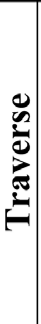 & 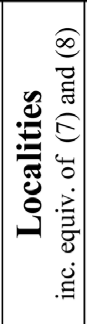 & $\begin{array}{l}\underline{u} \\
\frac{\boldsymbol{U}}{\boldsymbol{b}}\end{array}$ & 尝 & $\begin{array}{c}\text { UK } \\
\text { graptolite } \\
\text { biozone } \\
\text { (bold where } \\
\text { proven, or by } \\
\text { extrapolation; } \\
\text { bracketed where } \\
\text { strata affected by } \\
\text { slumping) }\end{array}$ & $\begin{array}{c}\text { Key Type Llandovery area } \\
\text { taxa/assemblages } \\
\text { (G- graptolites; B- brachiopods; taxa in each category are } \\
\text { listed alphabetically. Microfossil biozonal assemblages: } \\
\text { A- acritarchs; Ch- chitinozoans; } \mathbf{S} \text { - spores; Co- } \\
\text { conodonts) }\end{array}$ & 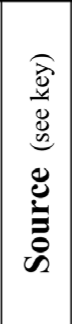 & $\begin{array}{l}\text { (see key for numbered sources given } \\
\text { in brackets) }\end{array}$ \\
\hline 1 & $\mathbf{a}$ & \begin{tabular}{|l|}
7147 \\
2596
\end{tabular} & Wow & sedgwickii-halli & $\begin{array}{l}\text { B. Clorinda globosa, Eocoelia hemispherica, Leangella } \\
\text { segmentum, Pentamerus oblongus, Stricklandia laevis* }\end{array}$ & 1,2 & $\begin{array}{l}\text { Basal } C_{4-5} \text { of }(1) \text { now recognised as } \\
\text { Wow; *FAD, } S \text {. lens ultima of (1) }\end{array}$ \\
\hline 1 & $\mathbf{b}$ & \begin{tabular}{|l|}
7175 \\
2564 \\
\end{tabular} & ?Dol & $\begin{array}{l}\text { ?spiralis - pre- } \\
\text { centrifugus }\end{array}$ & $\begin{array}{l}\text { B. Eocoelia transitional between E. curtisi and E. sulcata, } \\
\text { Costistricklandia lirata lirata }\end{array}$ & 12 & $\begin{array}{l}\text { Possibly affected by intra Wenlock } \\
\text { slide emplacement }\end{array}$ \\
\hline 1 & c & $\begin{array}{ll}7176 \\
2563\end{array}$ & BMd* & dubius & $\begin{array}{l}\text { G. cf. Monoclimacis flumendosae; Pristiograptus ex. gr. } \\
\text { dubius }\end{array}$ & TS & $\begin{array}{l}\text { *Drapes slide contact with ?Dol; see } \\
\text { Fig. } 14 \mathrm{k}, 1\end{array}$ \\
\hline 1 & d & \begin{tabular}{|l|}
71000 \\
2503
\end{tabular} & BMd & dubius & $\begin{array}{l}\text { G. Pristiograptus dubius s.l., monograptids of the } \\
\text { priodon/flemingii group }\end{array}$ & TS & $\begin{array}{l}\text { Stream section SW of Coed Shon; } \\
\text { see Fig. } 14 \mathrm{~m}-\mathrm{p}\end{array}$ \\
\hline 2 & \begin{tabular}{c|c}
$\mathbf{a}$ \\
$(168)$
\end{tabular} & $\begin{array}{l}7418 \\
2817\end{array}$ & ?Ceg ${ }^{\text {III }}$ & ?upper convolutus & $\begin{array}{l}\text { G. fragment of dendroid graptolite; B. Clo. undata, E. } \\
\text { hemispherica 'sefinensis }{ }^{*}{ }^{+}, \text {S. lens progressa }\end{array}$ & $\begin{array}{c}\mathrm{TS}, 3 \\
8\end{array}$ & $\begin{array}{l}\text { *FADs and type localities (3); } \\
+ \text { primitive morph of species (2) }\end{array}$ \\
\hline 2 & $\begin{array}{c}\mathbf{b} \\
(169)\end{array}$ & $\begin{array}{l}7418 \\
2812\end{array}$ & Ydw & lower sedgwickii & $\begin{array}{l}\text { G. Ne. tenuis*, St. sedgwickii; B. E. h. 'sefinensis', Clo. } \\
\text { undata**, L. scissa, Leptostrophia tenuis (abundant), } \\
\text { Meifodia prima supercedens, S. lens progressa }\end{array}$ & $\begin{array}{c}\mathrm{TS}, 3 \\
5,6,7 \\
18 \\
\end{array}$ & $\begin{array}{l}\text { 'Sefin Shales' of (3), but not } \mathrm{C}_{1} \text { of } \\
(4) ; * \text { lower biozone indicator in UK } \\
(9) ; * * \text { LAD in Llandovery area }\end{array}$ \\
\hline 2 & c & $\begin{array}{l}7420 \\
2814\end{array} \mid$ & Wow & lower sedgwickii & $\begin{array}{l}\text { G. Ne. tenuis*, Pr. cf. regularis**, St. sedgwickii**, To. } \\
\text { cf. magnificus**; B. Clo. globosa, E. hemispherica, } \\
\text { Eospirifer cf. radiatus, L. segmentum, P. oblongus; A. } \\
\text { estillis [MPA 55427] (inc. Micrhystridium intonsurans) }\end{array}$ & $\begin{array}{c}\mathrm{TS}, 3 \\
5\end{array}$ & $\begin{array}{l}\text { *Lower biozone indicator in UK (9); } \\
\text { **see Fig. 12a-c }\end{array}$ \\
\hline 2 & d & \begin{tabular}{|l|}
7373 \\
1801 \\
\end{tabular} & BMd & dubius & $\begin{array}{l}\text { G. aff. Mediograptus retroflexus, Pr. dubius dubius, Pr. } \\
\text { dubius pseudolatus }\end{array}$ & $\mathrm{TS}$ & $\begin{array}{l}\text { Overlies slide-plane contact with } \\
\text { disturbed Cer; see Fig. 14a-j }\end{array}$ \\
\hline 3 & $\mathbf{a}$ & \begin{tabular}{|l|}
7513 \\
3042 \\
\end{tabular} & $\mathrm{Gol}^{\mathrm{I}}$ & atavus-acinaces & A. fisheri & 7 & FAD in Llandovery area \\
\hline 4 & \begin{tabular}{c|c}
$\mathbf{a}$ \\
$(188)$
\end{tabular} & $\begin{array}{l}7460 \\
3025 \\
\end{array}$ & $\mathrm{ChF}^{\mathrm{I}}$ & $\begin{array}{l}\text { persculptus- } \\
\text { acuminatus }\end{array}$ & A. citrinipelatum & 7 & FAD in Llandovery area \\
\hline 4 & $\begin{array}{c}\mathbf{b} \\
(191) \\
\end{array}$ & $\begin{array}{l}7429 \\
3080 \\
\end{array}$ & $\mathrm{ChF}^{\mathrm{I}}$ & atavus-acinaces & A. robustispinosa & 7 & FAD in Llandovery area \\
\hline 4 & \begin{tabular}{c|}
$\mathbf{c}$ \\
$(178$ \\
$197)$
\end{tabular} & $\begin{array}{l}7534 \\
3086 \\
\end{array}$ & $\mathrm{Gol}^{\mathrm{I}}$ & atavus-acinaces & $\begin{array}{l}\text { B. Cryptothyrella crassa, L. scissa, Plectatrypa tripartita } \\
\text { tripartita*, S. lens prima**; A. fisheri }^{*}\end{array}$ & 7,8 & $\begin{array}{l}* \text { Type locality }(8) ; * * \mathrm{FAD} \text { in } \\
\text { Llandovery area }\end{array}$ \\
\hline 4 & $\begin{array}{c}\mathbf{d} \\
(98)\end{array}$ & \begin{tabular}{l|}
7568 \\
3087 \\
\end{tabular} & $\mathrm{Gol}^{\mathrm{II}}$ & atavus-acinaces & B. Borealis sp., S. lens prima; A. fisheri* [MPA 57667] & $\begin{array}{c}\mathrm{TS}, 7 \\
8\end{array}$ & $\begin{array}{l}\text { *LAD in area; listed as loc. } 181 \text { by } \\
(7, \text { fig. } 70), \text { but see }(7, \text { table } 4) \&(8)\end{array}$ \\
\hline 4 & \begin{tabular}{c|c}
$\mathbf{e}$ \\
$(181)$
\end{tabular} & $\begin{array}{l}7566 \\
3086 \\
\end{array}$ & $\mathrm{Gol}^{\mathrm{II}}$ & revolutus & $\begin{array}{l}\text { B. Pl. tripartita tripartita, S. lens intermedia*, } \\
\text { A. eoplanktonica [MPA 57667]* }\end{array}$ & \begin{tabular}{|c|} 
TS, 7 \\
8 \\
\end{tabular} & $\begin{array}{l}\text { *FADs in area; listed as loc. } 98 \text { by } \\
(7, \text { fig. } 70) \text {, but see }(7, \text { table } 4) \&(8)\end{array}$ \\
\hline 4 & $\begin{array}{c}\mathbf{f} \\
(183)\end{array}$ & $\begin{array}{l}7582 \\
3114\end{array}$ & $\operatorname{TrF}$ & revolutus & $\begin{array}{l}\text { B. ?Pl. tripartita subsp. nov.*, S. lens intermedia; } \mathbf{A} \text {. } \\
\text { eoplanktonica }\end{array}$ & 7,8 & $\begin{array}{l}\text { *FAD in Llandovery area (overlies } \\
\text { Gol }^{\mathrm{II}} \text { ) }\end{array}$ \\
\hline 4 & g & $\begin{array}{l}7587 \\
3123 \\
\end{array}$ & $\operatorname{TrF}$ & revolutus & $\begin{array}{l}\text { G. Metaclimacograptus } \text { ?undulatus }{ }^{*}, \text { Rhaphidograptus } \\
\text { toernquisti }^{* *} \text {; Ch. electa [07-201] }\end{array}$ & TS & $\begin{array}{l}* \text { Long ranging, but first appears in } \\
\text { revolutus Biozone; **Fig. } 12 \mathrm{v}-\mathrm{x}\end{array}$ \\
\hline 4 & $\begin{array}{c}\mathbf{h} \\
(\approx 184)\end{array}$ & $\begin{array}{l}7611 \\
3134\end{array}$ & $\operatorname{TrF}$ & \begin{tabular}{|c|} 
? upper \\
leptotheca - lower \\
convolutus
\end{tabular} & $\begin{array}{l}\text { G.?M. limatulus } * \text { B. Clo. undata, L. scissa, ?Pl. tripartita } \\
\text { subsp. nov., S. lens intermedia; A. eoplanktonica; Ch. } \\
\text { maennili (inc. E. cf. dolioliformis) [07-202] }\end{array}$ & $\begin{array}{c}\mathrm{TS}, 4 \\
7\end{array}$ & $\begin{array}{l}\text { Between } \mathrm{Ceg}^{0} \text { and } \mathrm{Ceg}^{1} ; * \text { first } \\
\text { appears in upper leptotheca Biozone } \\
\text { in UK (9) }\end{array}$ \\
\hline 4 & \begin{tabular}{c|}
$\mathbf{i}$ \\
$(120)$
\end{tabular} & $\begin{array}{l}7604 \\
3091 \\
\end{array}$ & $\mathrm{Ceg}^{\mathrm{I}}$ & lower convolutus & $\begin{array}{l}\text { B. Clo. undata, L. scissa, Lep. anticedens*, Mei. prima } \\
\text { ovalis**, ?Pl. tripartita } \text { sp. nov., S. lens intermedia }\end{array}$ & 7,8 & $\begin{array}{l}\text { *LAD in Llandovery area; **Type } \\
\text { locality (8) }\end{array}$ \\
\hline 5 & \begin{tabular}{c|c}
$\mathbf{a}$ \\
$(198)$
\end{tabular} & $\begin{array}{l}7543 \\
3206 \\
\end{array}$ & $\mathrm{Gol}^{\mathrm{I}}$ & atavus-acinaces & A. fisheri & 7 & FAD in this section \\
\hline 5 & $\begin{array}{c}\mathbf{b} \\
(353)\end{array}$ & $\begin{array}{l}7580 \\
3195\end{array}$ & $\mathrm{Gol}^{\mathrm{I}}$ & atavus-acinaces & B. Borealis sp.*, Mei. prima prima, S. lens prima** & 8 & $\begin{array}{l}\text { *FAD in Llandovery area; ** LAD } \\
\text { in Llandovery area }\end{array}$ \\
\hline 5 & $\begin{array}{c}\mathbf{c} \\
(7021) \\
\end{array}$ & $\begin{array}{l}7622 \\
3247 \\
\end{array}$ & $\mathrm{Gol}^{\mathrm{I}}$ & atavus-acinaces & $\begin{array}{l}\text { B. Cr. crassa }{ }^{+}, \text {Mei. prima prima, Pl. tripartita tripartita*, } \\
\text { S. lens lens } *^{+}\end{array}$ & 8 & $\begin{array}{l}\text { * LADs in Llandovery area; }{ }^{+} \text {type } \\
\text { localities (8) }\end{array}$ \\
\hline 5 & d & $\begin{array}{l}7630 \\
3201\end{array}$ & $\operatorname{TrF}$ & revolutus & G. $N$. cf. wyensis ${ }^{*}, R$. toernquist $i$ & TS & $\begin{array}{l}\text { *Biozone indicator; between } \mathrm{Gol}^{\mathrm{II}} \\
\text { and Ceg }{ }^{0} \text {; see Fig. } 12 \mathrm{y}\end{array}$ \\
\hline 5 & e & \begin{tabular}{|l|}
7695 \\
3164 \\
\end{tabular} & $(\mathrm{BMd})$ & (riccartonensis) & G. $M$. riccartonensis & TS & $\begin{array}{l}\text { From slump/slide-disturbed } \\
\text { succession }\end{array}$ \\
\hline 6 & \begin{tabular}{c|c}
$\mathbf{a}$ \\
$(141)$
\end{tabular} & $\begin{array}{l}7760 \\
3328\end{array}$ & $\mathrm{ChF}^{\mathrm{I}}$ & ? triangulatus & G. Pseudoglyptograptus vas, $R$. toernquist $i$ & $\mathrm{TS}, 7$ & $\begin{array}{l}\text { Underlies FAD of Neo. magnus [6b] } \\
\text { in this section [see 11d] }\end{array}$ \\
\hline 6 & \begin{tabular}{c|}
$\mathbf{b}$ \\
$(142)$
\end{tabular} & $\begin{array}{l}7759 \\
3326\end{array}$ & $\mathrm{ChF}^{\mathrm{I}}$ & magnus & $\begin{array}{l}\text { G. Glyptograptus tamariscus tamariscus, M. triangulatus } \\
\text { fimbriatus, Neodiplograptus magnus* }\end{array}$ & 7 & $\begin{array}{l}\text { *Biozone indicator in UK (9) and } \\
\text { FAD in this section [see } 11 \mathrm{e}]\end{array}$ \\
\hline 6 & \begin{tabular}{c|c}
$\mathbf{c}$ \\
$(143)$
\end{tabular} & $\begin{array}{l}7759 \\
3326 \\
\end{array}$ & $\mathrm{ChF}^{\mathrm{I}}$ & lower convolutus & $\begin{array}{l}\text { G. ?G. incertus }{ }^{*}, \text { Petalolithus minor, Rivagraptus } \mathrm{cf} . \\
\text { cyperoides; A. eoplanktonica [MPA 55428] }\end{array}$ & $\mathrm{TS}, 7$ & $\begin{array}{l}\text { Closely overlies [6b]; *common } \\
\text { post-leptotheca Biozone in UK (9) }\end{array}$ \\
\hline 6 & $\begin{array}{c}\mathbf{d} \\
(216)\end{array}$ & $\begin{array}{l}7755 \\
3302 \\
\end{array}$ & $\operatorname{Rdg}$ & $\begin{array}{l}\text { middle } \\
\text { convolutus }\end{array}$ & B. Clorinda community brachiopods; A. microcladum* & 6,7 & *FAD in this section \\
\hline
\end{tabular}

Figure A1. Details for key Llandovery area fossil localities [1a] to [6d]. 


\begin{tabular}{|c|c|c|c|c|c|c|c|}
\hline 6 & \begin{tabular}{c|c}
$\mathbf{e}$ \\
$(220)$
\end{tabular} & $\begin{array}{l}7758 \\
3285\end{array}$ & Rdg & upper convolutus & A. estellis & 7 & FAD in this section \\
\hline 6 & $\begin{array}{c}\mathbf{f} \\
(156)\end{array}$ & \begin{tabular}{|l|}
7749 \\
3257 \\
\end{tabular} & $\mathrm{Ydw}^{*}$ & sedgwickii & $\begin{array}{l}\text { B. Eospirifer aff. radiatus }{ }^{* *} \text {, Dicoelosia alticavata } \\
\text { (abundant); S. } \text { membranifera*** }\end{array}$ & 7,23 & $\begin{array}{l}* \text { Rhydings Fm of }(7) ; * * \mathrm{FAD} \text { of } \\
\text { genus in area; } * * * \text { diversity min. }(23)\end{array}$ \\
\hline 6 & $\underset{(157)}{\mathbf{g}}$ & $\begin{array}{l}7749 \\
3255\end{array}$ & Ydw* & sedgwickii & $\begin{array}{l}\text { B. Clo. globosa, D. alticavata (abundant), E. } \\
\text { intermedia } * *, \text { L. scissa, S. lens progressa }\end{array}$ & 7 & $\begin{array}{l}\text { *Rhydings Formation of }(7) ; * * \mathrm{FAD} \\
\text { in Llandovery area }\end{array}$ \\
\hline 6 & \begin{tabular}{c|c}
$\mathbf{h}$ \\
$(159)$
\end{tabular} & $\begin{array}{l}7744 \\
3241\end{array}$ & Wow & sedgwickii-halli & $\begin{array}{l}\text { A. estillis (inc. Dilatisphaera laevigata); } \mathbf{S} . \\
\text { membranifera* }\end{array}$ & 7,23 & *LAD in Llandovery area \\
\hline 6 & $\mathbf{i}$ & $\begin{array}{l}7742 \\
3234\end{array}$ & Wow & sedgwickii-halli & Ch. dolioliformis [P5726-29] & 16 & $\begin{array}{l}\text { LAD in area; known elsewhere to } \\
\text { range into the turriculatus Biozone }\end{array}$ \\
\hline 6 & \begin{tabular}{|c|c|}
$\mathbf{j}$ \\
$(162)$
\end{tabular} & $\begin{array}{l}7742 \\
3233 \\
\end{array}$ & Wow & sedgwickii-halli & $\begin{array}{l}\text { B. Clo. globosa, E. intermedia*, L. scissa*, L. segmentum, } \\
\text { S. lens progressa*; A. estellis; S. avitus-dilatus** }\end{array}$ & $\begin{array}{c}7,19 \\
23\end{array}$ & $\begin{array}{l}0.2 \mathrm{~m} \text { below Telychian GSSP; } \\
\text { *LADs and **FAD in area }\end{array}$ \\
\hline 6 & \begin{tabular}{c|c}
$\mathbf{k}$ \\
$(187)$
\end{tabular} & \begin{tabular}{l|}
7743 \\
3231
\end{tabular} & Wow & sedgwickii-halli & B. Pentlandella pentlandica & 7 & FAD of genus in Llandovery area \\
\hline 6 & 1 & $\begin{array}{l}7877 \\
3269\end{array}$ & Wow & sedgwickii-halli & B. Clo. globosa, L. segmentum, P. oblongus, S. laevis* & 3,19 & $\begin{array}{l}\text { *S. lens ultima of Williams (1951) } \\
\text { (type locality) }\end{array}$ \\
\hline 6 & m & $\begin{array}{l}7747 \\
3231\end{array}$ & $(\mathrm{BMd})$ & (riccartonensis) & $\begin{array}{l}\text { G. } M . \text { riccartonensis } * \text {, M. cf. riccartonensis } * \text {, M. aff. } \\
\text { riccartonensis }(\mathrm{Z} \& \mathrm{~W}, 1999)^{*} ; \text { Ch. margaritana }[08- \\
1967]^{* *}\end{array}$ & $\begin{array}{c}\text { TS } \\
10\end{array}$ & $\begin{array}{l}\text { From slide-bound slice of Wenlock } \\
\text { strata (Fig. 4D); *see Fig.14q-s, y- } \\
\text { bb; ** see Fig. 16a }\end{array}$ \\
\hline 6 & $\begin{array}{c}\mathbf{n} \\
(163)\end{array}$ & $\begin{array}{l}7746 \\
3229\end{array}$ & debrite & (?dubius) & $\begin{array}{l}\text { Clo. globosa, E. curtisi*, Eo. cf. radiatus, L. segmentum, } \\
\text { Lep. compressa, S. laevis; A. monospinosa; } \mathbf{C h .} \\
\text { margaritana }[09-2184]^{* *} ; \text { S. avitus-dilatus }\end{array}$ & $\begin{array}{c}\mathrm{TS}, 7 \\
10, \\
23\end{array}$ & $\begin{array}{l}\text { From mélange (Fig. 4D); * primitive } \\
\text { morph (7); **proves Wenlock age of } \\
\text { clast/matrix (10), see Fig. 16c,i }\end{array}$ \\
\hline 6 & $\mathbf{0}$ & $\begin{array}{l}7749 \\
3228\end{array}$ & $\mathrm{BMd}^{*}$ & ?dubius & G. $M$. cf. riccartonensis; cf. Pristiograptus ex. gr. dubius & $\begin{array}{c}\mathrm{TS} \\
10\end{array}$ & $\begin{array}{l}\text { *Drapes slide-plane contact with } \\
\text { disturbed Cer (Fig. 4D); Fig. 14t-x }\end{array}$ \\
\hline 7 & $\mathbf{a}$ & \begin{tabular}{|l|}
7856 \\
3415 \\
\end{tabular} & $\mathrm{ChF}^{\mathrm{I}}$ & lower convolutus & $\begin{array}{l}\text { A. eoplanktonica [MPA 55430]*; Ch. maennili [08-1989] } \\
\text { (inc. E. cf. dolioliformis) }\end{array}$ & TS & $\begin{array}{l}\text { Underlies distal Ceg }{ }^{\mathrm{I}} / \mathrm{TrF} \text { succession } \\
\text { (Fig. 4A); * see Fig. 15b }\end{array}$ \\
\hline 7 & $\mathbf{b}$ & $\begin{array}{l}7862 \\
3412 \\
\end{array}$ & $\mathrm{ChF}^{\mathrm{II}}$ & $\begin{array}{l}\text { middle } \\
\text { convolutus }\end{array}$ & $\begin{array}{l}\text { G. graptolite fragments; A. microcladum [MPA 55432]*; } \\
\text { Ch. maennili (inc. E. cf. dolioliformis) [08-1990] }\end{array}$ & TS & $\begin{array}{l}\text { *FAD in area; overlies attenuated } \\
\text { Ceg } / \text { TrF succession; * see Fig. } 15 \mathrm{c}-\mathrm{e}\end{array}$ \\
\hline 7 & c & $\begin{array}{l}7877 \\
3404\end{array}$ & Rdg & $\begin{array}{c}\text { middle } \\
\text { convolutus }\end{array}$ & Ch. maennili Biozone chitinozoans [08-1993] & TS & See Fig. 16e,f \\
\hline 7 & \begin{tabular}{c|c}
$\mathbf{d}$ \\
$(109)$
\end{tabular} & $\begin{array}{l}7820 \\
3334\end{array}$ & $\mathrm{Ceg}^{\text {II }}$ & $\begin{array}{l}\text { middle } \\
\text { convolutus }\end{array}$ & B. Clo. globosa*, Clo. cf. undata, L. scissa, & 4,7 & *FAD in Landovery area \\
\hline 7 & e & $\begin{array}{l}7867 \\
3378 \\
\end{array}$ & Rdg & upper convolutus & G. cf. Campograptus harpago*, cf. Met. undulatus & TS & $\begin{array}{l}\text { *Upper biozone indicator in UK (9), } \\
\text { FAD in area; see Fig. 12i-r }\end{array}$ \\
\hline 7 & f & $\begin{array}{l}7885 \\
3400 \\
\end{array}$ & $\mathrm{ChF}^{\mathrm{II}}$ & upper convolutus & $\begin{array}{l}\text { G. Ca. Lobiferus*; A. estillis [MPA 55435]**; Ch. } \\
\text { dolioliformis [08-1994]** }\end{array}$ & TS & $\begin{array}{l}\text { On strike with }[7 \mathrm{e}], * \text { abund. in bioz. } \\
(9) ; * * \text { FADs in area; Figs } 15 \mathrm{f}, \mathrm{g}, 16 \mathrm{~d}\end{array}$ \\
\hline 7 & g & \begin{tabular}{l|}
7827 \\
3325 \\
\end{tabular} & Ydw & sedgwickii & $\begin{array}{l}\text { G. M. cf. marri*, B. Clo. globosa, L. segmentum } * *, P \text {. } \\
\text { oblongus }\end{array}$ & 4,19 & $\begin{array}{l}\text { *Probable misidentification by (4); } \\
\text { **FAD in Llandovery area (19) }\end{array}$ \\
\hline 7 & $\mathbf{h}$ & $\begin{array}{l}7847 \\
3338\end{array}$ & Ydw & sedgwickii & B. L. scissa, P. oblongus (abundant) & $20 *$ & *Locality given as 'Penlan Quarry' \\
\hline 7 & $\mathbf{i}$ & $\begin{array}{l}7930 \\
3389\end{array}$ & $\mathrm{BMd} *$ & dubius & G. M. flumendosae, M. retroflexus ${ }^{* *}$, Pr. ex gr. dubius & TS & $\begin{array}{l}\text { *Drapes slide-plane contact with } \\
\text { Cer; **UK FAD in dubius Biozone } \\
\text { (9); see Fig. 14cc-ee }\end{array}$ \\
\hline 8 & $\mathbf{a}$ & \begin{tabular}{l|}
7880 \\
3562 \\
\end{tabular} & $\mathrm{ChF}^{\mathrm{I}}$ & persculptus & $\begin{array}{l}\text { G. Normalograptus? parvulus*, Persculptograptus } \\
\text { persculptus }\end{array}$ & 11 & *Morphology 2 (see 11) \\
\hline 8 & $\mathbf{b}$ & $\begin{array}{l}8035 \\
3488 \\
\end{array}$ & $\mathrm{BMd}^{*}$ & $\begin{array}{l}\text { middle dubius- } \\
\text { rigidus }\end{array}$ & G. $M$. flexilis & TS & $\begin{array}{l}\text { *Drapes slide-plane contact with } \\
\text { Cer; FAD in mid dubius Biozone (9) }\end{array}$ \\
\hline 9 & $\mathbf{a}$ & $\begin{array}{l}7995 \\
3771 \\
\end{array}$ & Tyc & persculptus & G. Normalograptus? parvulus & TS & $\begin{array}{l}\text { Too poorly preserved to allow } \\
\text { morphological diagnosis }\end{array}$ \\
\hline 9 & $\begin{array}{c}\mathbf{b} \\
(81)\end{array}$ & $\begin{array}{l}8122 \\
3829\end{array}$ & $\mathrm{BrF}$ & $\begin{array}{l}\text { upper atavus- } \\
\text { acinaces }\end{array}$ & $\begin{array}{l}\text { G. Cl. angustus, Pseudoclimacograptus fidus/pictus, } R \text {. } \\
\text { toernquisti* }\end{array}$ & 7 & $\begin{array}{l}\text { Cited as acuminatus Biozone by (7), } \\
\text { but* has FAD in upper atavus } \\
\text { Biozone in UK (9) }\end{array}$ \\
\hline 9 & c & $\begin{array}{l}8114 \\
3803\end{array}$ & $\mathrm{ChF}^{\mathrm{I}}$ & revolutus & $\begin{array}{l}\text { G. cf. Atavograptus atavus, Gl. cf. tamariscus varians*, } \\
\text { Normalograptus sp. }\end{array}$ & TS & $\begin{array}{l}\text { *Biozone indicator }(9) \text { and FAD of } \\
\text { revolutus Biozone graptolites; see } \\
\text { Fig. } 12 \mathrm{~s}-\mathrm{u} \text {; same level as [10c \& d] }\end{array}$ \\
\hline 9 & \begin{tabular}{c|}
$\mathbf{d}$ \\
$(100)$
\end{tabular} & $\begin{array}{l}8207 \\
3837\end{array}$ & $\operatorname{TrF}$ & magnus & $\begin{array}{l}\text { G. } \text { M. cf. revolutus, } \text { M. triangulatus ?fimbriatus, } M \text {. } \\
\text { triangulatus ?separatus, } N \text {. cf. magnus*, } \text { R. toernquisti }\end{array}$ & 7 & *Biozone indicator in UK (9) \\
\hline 9 & \begin{tabular}{c|c}
$\mathbf{e}$ \\
$(101)$
\end{tabular} & \begin{tabular}{l|}
8147 \\
3771 \\
\end{tabular} & $\operatorname{TrF}$ & lower convolutus & $\begin{array}{l}\text { G. Cl. retroversus, Lituigraptus aff. convolutus } *, R \text {. } \\
\text { toernquisti }\end{array}$ & 7 & $\begin{array}{l}\text { * Lower biozone indicator in UK (9); } \\
\text { placed in sedgwickii Biozone by (7) }\end{array}$ \\
\hline 9 & f & \begin{tabular}{|l|}
819 \\
379
\end{tabular} & Ceg ${ }^{\text {III }}$ & $\begin{array}{c}\text { upper } \\
\text { convolutus }\end{array}$ & B. Mei. prima supercedens & 3,8 & LAD in Llandovery area \\
\hline 9 & g & \begin{tabular}{|l|}
8169 \\
3752 \\
\end{tabular} & Ydw & lower sedgwickii & G. Rastrites sp. (gracilis?), Ne. cf. tenuis*, St. sedgwickii & $\begin{array}{c}\mathrm{TS} \\
10\end{array}$ & $\begin{array}{l}\text { *Lower biozone indicator in UK (9), } \\
\text { FAD in area; see Figs. 4E \& } 12 \mathrm{~d}-\mathrm{h}\end{array}$ \\
\hline 9 & $\begin{array}{c}\mathbf{h} \\
(5 \mathrm{a})\end{array}$ & $\begin{array}{l}8171 \\
3751\end{array}$ & Ydw & lower sedgwickii & G. $R$. toernquisti & 7 & $\begin{array}{l}\text { LAD in area; overlies [9g]; unknown } \\
\text { above lower biozone in UK (9) }\end{array}$ \\
\hline 10 & $\begin{array}{c}\text { a } \\
(92)\end{array}$ & $\begin{array}{l}8323 \\
3975 \\
\end{array}$ & $\mathrm{BrF}$ & atavus-acinaces & Co. descreta-deflecta & 7 & $\begin{array}{l}\text { Only published conodont } \\
\text { assemblage from the area }\end{array}$ \\
\hline 10 & $\mathbf{b}$ & $\begin{array}{l}8269 \\
3911\end{array}$ & $\mathrm{CcF}^{\mathrm{I}}$ & atavus-acinaces & $\begin{array}{l}\text { electa Biozone chitinozoans (abundant Belonechitina } \\
\text { postrobusta*) [08-1997] }\end{array}$ & TS & *see Fig. 16b,g \\
\hline
\end{tabular}

Figure A2. Details for key Llandovery area fossil localities [6e] to [10b]. 


\begin{tabular}{|c|c|c|c|c|c|c|c|}
\hline 10 & c & $\begin{array}{l}8197 \\
3851\end{array}$ & $\mathrm{ChF}^{\mathrm{I}}$ & revolutus & $\begin{array}{l}\text { G. C. hughesi, N. medius*, N. normalis, Pribylograptus } \\
\text { incommodus }\end{array}$ & 4 & $\begin{array}{l}\text { *unknown above revolutus Bioz. in } \\
\text { UK (9); same horizon as [9c \& 10d] }\end{array}$ \\
\hline 10 & \begin{tabular}{c|c}
$d$ \\
$(37)$
\end{tabular} & $\begin{array}{l}8269 \\
3910\end{array}$ & $\operatorname{TrF}$ & revolutus & $\begin{array}{l}\text { G. } N . \text { normalis, Pri. incommodus; B. Clo. undata, L. } \\
\text { scissa }\end{array}$ & 4,7 & Same horizon as [9c] and [10c] \\
\hline 10 & \begin{tabular}{c|c}
$\mathbf{e}$ \\
$(36)$
\end{tabular} & \begin{tabular}{|}
8327 \\
3929 \\
\end{tabular} & $\mathrm{Ceg}^{\mathrm{I}}$ & lower convolutus & $\begin{array}{l}\text { G. } \text { Ca. } \text { cf. lobiferus, } N \text {. scalaris } * *, P r \text {. regularis*, } R \text {. } \\
\text { toernquisti, Ri. cyperoides, Torquigraptus? decipiens }\end{array}$ & 7,13 & $\begin{array}{l}\text { *Biozone indicator in UK (9); } \\
* * \text { abundant in convolutus Biozone } \\
\end{array}$ \\
\hline 11 & $\begin{array}{c}\mathbf{a} \\
(41 \mathrm{a})\end{array}$ & $\begin{array}{l}8410 \\
3963 \\
\end{array}$ & $\mathrm{CcF}^{\mathrm{II}}$ & revolutus & B. L. scissa, S. lens intermedia* & 7,8 & *FAD in Llandovery area \\
\hline 11 & \begin{tabular}{c|}
$\mathbf{b}$ \\
$(38 \mathrm{a})$
\end{tabular} & $\begin{array}{l}8390 \\
3960\end{array}$ & $\operatorname{TrF}$ & revolutus & $\begin{array}{l}\text { B. Mei. subundata; A. eoplanktonica [MPA 55441]; Ch. } \\
\text { maennili Biozone [08-2000]* }\end{array}$ & $\mathrm{TS}, 7$ & $\begin{array}{l}\text { *FAD in Llandovery area; see Fig. } \\
4 \mathrm{C}\end{array}$ \\
\hline 11 & $\begin{array}{c}\mathbf{c}(70 \\
70 \mathrm{a})\end{array}$ & $\begin{array}{l}8386 \\
3958 \\
\end{array}$ & $\operatorname{TrF}$ & revolutus & $\begin{array}{l}\text { G. D. corrugatellum, Huttagraptus acinaces, M. austerus } \\
\text { vulgaris*; B. Pl. tripartita subsp. nov.**, S. l. intermedia }\end{array}$ & 7,8 & $\begin{array}{l}18 \mathrm{~m} \text { below Aeronian GSSP; *UK } \\
\text { biozone indicator }(9) ; * * \mathrm{FAD} \text { in area }\end{array}$ \\
\hline 11 & $\begin{array}{c}\mathbf{d} \\
(72)\end{array}$ & $\begin{array}{l}8382 \\
3955\end{array}$ & $\mathrm{Ceg}^{0}$ & $\begin{array}{c}\text { middle } \\
\text { triangulatus }\end{array}$ & $\begin{array}{l}\text { G. C. retroversus, } M . \text { a. sequens*; B. Clo. undata, } P l . \\
\text { tripartita subsp. nov., S. lens intermedia; A. eoplanktonica } \\
\text { [MPA 55442]**; Ch. maennili }[07-209,08-1982]^{+}\end{array}$ & $\begin{array}{c}\mathrm{TS}, 7 \\
8\end{array}$ & $\begin{array}{l}\text { Immediately overlies Aeronian } \\
\text { GSSP; *middle biozone indicator in } \\
\text { UK (9); **Fig. 15i,j; }{ }^{+} \text {Fig. } 16 \mathrm{~h}\end{array}$ \\
\hline 11 & $\begin{array}{c}\mathbf{e} \\
(73)\end{array}$ & $\begin{array}{l}8381 \\
3951\end{array}$ & $\operatorname{TrF}$ & magnus & $\begin{array}{l}\text { G. C. retroversus, Neo. magnus*, Pse. vas, Ra. peregrinus, } \\
\text { R. toernquisti; B. Clo. undata; A. eoplanktonica [MPA } \\
55443]^{* * ;} \text { Ch. maennili [P5728-49] }\end{array}$ & 7,8 & $\begin{array}{l}\text { *Biozone indicator in UK (9) and } \\
\text { FAD in Llandovery area; ** see Fig. } \\
151,0, p\end{array}$ \\
\hline 11 & $\begin{array}{c}\mathbf{f} \\
(75)\end{array}$ & $\begin{array}{l}8377 \\
3945 \\
\end{array}$ & $\mathrm{Ceg}^{\mathrm{I}}$ & magnus & \begin{tabular}{|l|} 
G. C. retroversus $*$, D. venustus $*$, B. Cl. undata, S. lens \\
intermedia; Ch. maennili (inc. cf. dolioliformis) [08-2013]
\end{tabular} & $\begin{array}{c}\mathrm{TS}, 7 \\
8\end{array}$ & $\begin{array}{l}\text { *Long ranging (9); between magnus } \\
\text { Biozone assemblages of [11e \& } 11 \mathrm{~g}]\end{array}$ \\
\hline 11 & $\mid \begin{array}{c}\mathbf{g} \\
(38 \mathrm{c})\end{array}$ & $\begin{array}{l}8369 \\
3940\end{array} \mid$ & $\mathrm{Ceg}^{\mathrm{I}}$ & ?magnus & $\begin{array}{l}\text { G. ?A. atavus, Discograptus sp.; B. Cl. undata, Mei. prima } \\
\text { prima, P. tripartita subsp. nov., S. lens intermedia; A. } \\
\text { eoplanktonica [MPA 55445] }\end{array}$ & 7 & $\begin{array}{l}\text { Graptolites are long ranging, but } A \text {. } \\
\text { atavus does not range above magnus } \\
\text { Biozone in UK (9) }\end{array}$ \\
\hline 11 & $\begin{array}{c}\mathbf{h} \\
(39)\end{array}$ & $\begin{array}{l}8366 \\
3938\end{array}$ & $\mathrm{Ceg}^{\mathrm{I}}$ & lower convolutus & $\begin{array}{l}\text { G. C. retroversus, Pristiograptus regularis*; B. Mei. } \\
\text { prima prima }\end{array}$ & 7,8 & $\begin{array}{l}\text { *Biozone indicator in UK (9) and } \\
\text { closely overlies magnus Biozone } \\
\text { fauna of [11g] }\end{array}$ \\
\hline 11 & \begin{tabular}{c|c}
$\mathbf{i}$ \\
$(76)$
\end{tabular} & $\begin{array}{l}8351 \\
3922 \\
\end{array}$ & $\mathrm{Ceg}^{\mathrm{I}}$ & lower convolutus & $\begin{array}{l}\text { B. M. prima ovalis*, P. tripartita subsp. nov.*, S. lens } \\
\text { intermedia*; S. membranifera }\end{array}$ & 8,23 & *LADs in Llandovery area \\
\hline 11 & $\begin{array}{c}\mathbf{j} \\
(89)\end{array}$ & \begin{tabular}{|r|}
8348 \\
3920
\end{tabular} & $\mathrm{Ceg}^{\mathrm{I}}$ & lower convolutus & G. Graptolite indet. & $\mathrm{TS}, 7$ & $\begin{array}{l}\text { M. cf. sedgwickil } \\
\text { (7) not confirmec }\end{array}$ \\
\hline 12 & $\begin{array}{c}\mathbf{a} \\
(\approx 24)\end{array}$ & $\begin{array}{l}8457 \\
3956 \\
\end{array}$ & GHF & ?extraordinarius & Ch. ?taugourdeaui; S. membranifera & $\begin{array}{l}21, \\
23\end{array}$ & $\begin{array}{l}\text { Pre-dates FAD of persculptus } \\
\text { Biozone graptolites in Wales (11) }\end{array}$ \\
\hline 12 & \begin{tabular}{|c|c|}
$\mathbf{b}$ \\
$(88)$
\end{tabular} & $\begin{array}{l}8456 \\
3957 \\
\end{array}$ & $\mathrm{BrF}$ & persculptus & G. $N$. normalis & 7 & $\begin{array}{l}\text { c. } 10 \mathrm{~m} \text { above base BrF; morphology } \\
\text { indicates persculptus Biozone (7) }\end{array}$ \\
\hline 12 & $\begin{array}{c}\mathbf{c} \\
(61 \mathrm{a})\end{array}$ & $\begin{array}{l}8452 \\
3954 \\
\end{array}$ & $\mathrm{BrF}$ & & B. Cr. angustifrons, Parastrophinella sp. & 7,8 & FADs in Llandovery area \\
\hline 12 & \begin{tabular}{c|c}
$\mathbf{d}$ \\
$(26)$
\end{tabular} & $\begin{array}{l}8450 \\
3955 \\
\end{array}$ & $\mathrm{BrF}$ & ?atavus-acinaces & $\begin{array}{l}\text { G. } N \text {. cf. normalis, } N \text {. rectangularis; } \text { B. Cr. angustifrons, } \\
\text { L. scissa*, Lep.antecedens }{ }^{*} \text {, Parastrophinella sp. }\end{array}$ & 7,8 & $\begin{array}{l}\text { Lacks younger biozon } \\
\text { (7); *FADs in Llando }\end{array}$ \\
\hline 12 & \begin{tabular}{c|c}
$\mathbf{e}$ \\
$(27)$
\end{tabular} & $\begin{array}{l}8447 \\
3954 \\
\end{array}$ & $\mathrm{BrF}$ & atavus-acinaces & B. Clo. undata*, Cr. crassa*, L. scissa, Mei. prima prima* & 7,8 & *FADs in Llandovery area \\
\hline 12 & $\begin{array}{c}\mathbf{f} \\
(\approx 224)\end{array}$ & $\begin{array}{l}8439 \\
3953 \\
\end{array}$ & $\mathrm{BrF}^{*}$ & atavus-acinaces & B. S. lens lens; Ch. electa [P5729-64] & $\begin{array}{c}\mathrm{TS}, 8 \\
16 \\
\end{array}$ & $\begin{array}{l}\text { FADs in Llandovery area; * sampled } \\
\text { as basal CcF by }(8) \text { and (16) }\end{array}$ \\
\hline 12 & \begin{tabular}{|c|}
$\mathbf{g}$ \\
$(65)$
\end{tabular} & $\begin{array}{l}8417 \\
3944 \\
\end{array}$ & $\mathrm{CcF}^{\mathrm{I}}$ & atavus-acinaces & $\begin{array}{l}\text { B. Mei. prima ovalis*, } \text { Pl. tritartita tr. } \\
\text { membranifera }\end{array}$ & 8,23 & *FAD in N. Llandovery area \\
\hline 12 & \begin{tabular}{|c|}
$\mathbf{h}$ \\
$(35)$
\end{tabular} & \begin{tabular}{|l|}
8397 \\
3907 \\
\end{tabular} & $\mathrm{CcF}^{\mathrm{II}}$ & $\begin{array}{l}\text { middle-upper } \\
\text { revolutus }\end{array}$ & $\begin{array}{l}\text { G. C. hughesi, Hu. ?strachani, } N . \text { rectangularis, } \\
\text { triangulate monograptid thecae*; Ch. electa [P5729-66] }\end{array}$ & $\begin{array}{c}\mathrm{TS}, 7 \\
16 \\
\end{array}$ & $\begin{array}{l}\text { Is first } \\
\text { one }(7,9)\end{array}$ \\
\hline 12 & $\begin{array}{c}\mathbf{i}(201- \\
204)\end{array}$ & $\begin{array}{l}836 \\
389 \\
\end{array}$ & $\mathrm{Ceg}^{\mathrm{I}}$ & lower convolutus & $\begin{array}{l}\text { B. Clo. undata, Mei. prima prima*, Pl. tripartita subsp. } \\
\text { nov, S. lens intermedia }\end{array}$ & 8 & $\begin{array}{l}\text { *LAD in Llandovery area; see Fig. } \\
\text { 4B }\end{array}$ \\
\hline 12 & $\begin{array}{c}\mathbf{j} \\
(14)\end{array}$ & $\begin{array}{l}8348 \\
3892\end{array}$ & $\mathrm{Ceg}^{\mathrm{I}}$ & lower convolutus & $\begin{array}{l}\text { G. Glyptograptus sp., Monograptus sp., Ra. aff. linnaei, } \\
\text { Ri. cf. bellulus*; B.P. oblongus**; Ch. maennili (inc. E. } \\
\text { cf. dolioliformis) [P5728-34] }\end{array}$ & 7 & $\begin{array}{l}\text { *supports pre-sedgwickii Biozone } \\
\text { age (9) (contrary to } 7) ; * * \text { FAD in } \\
\text { Llandovery area }\end{array}$ \\
\hline 13 & a & \begin{tabular}{|l|}
834 \\
374 \\
\end{tabular} & $\operatorname{TrF}$ & revolutus & B. $S$. lens intermedia & 3 & Type locality (3) \\
\hline 13 & b & \begin{tabular}{|l|}
8305 \\
3775 \\
\end{tabular} & $\operatorname{Rdg}$ & $\begin{array}{l}\text { middle } \\
\text { convolutus }\end{array}$ & A. microcladum [MPA 55440]*; Ch. & TS & *FAD in N. Llandovery area \\
\hline 13 & c & \begin{tabular}{|l|}
830 \\
371 \\
\end{tabular} & $\mathrm{Ceg}^{\mathrm{II}}$ & $\begin{array}{c}\text { middle } \\
\text { convolutus }\end{array}$ & B. Mei. prima supercedens & \begin{tabular}{c|}
3,8 \\
14
\end{tabular} & $\begin{array}{l}\text { Holotype locality (3) and FAD in } \\
\text { Llandovery area }\end{array}$ \\
\hline 14 & $\begin{array}{c}\mathbf{a} \\
(126) \\
\end{array}$ & \begin{tabular}{|l|}
8477 \\
3713 \\
\end{tabular} & $\mathrm{CcF}^{\mathrm{I}}$ & atavus-acinaces & B. Pl. tripartita tripartita & 8 & FAD in Llandovery area \\
\hline 14 & b & $\begin{array}{l}8433 \\
3645 \\
\end{array}$ & $\mathrm{DD}^{\mathrm{I}}$ & upper convolutus & B. P. oblongus; A. estillis [MPA 55446]* & $\begin{array}{l}\text { TS, } \\
13\end{array}$ & *FAD in N. Llandovery area \\
\hline 14 & c & $\begin{array}{l}8440 \\
3644\end{array}$ & Wow & sedgwickii-halli & A. estillis [MPA 55447]*; Ch. dolioliformis [08-2016] & TS & *see Fig. $15 \mathrm{~h}, \mathrm{k}, \mathrm{m}$ \\
\hline 15 & a & \begin{tabular}{l|}
8540 \\
3843 \\
\end{tabular} & $\mathrm{DD}^{\mathrm{II}}$ & sedgwickii-halli & $\begin{array}{l}\text { B. } \text { P. oblongus; A. estillis [MPA55449] (inc. } \\
\text { Dilatisphaera laevigata*) }\end{array}$ & $\begin{array}{l}\text { TS, } \\
13\end{array}$ & *see Fig. 15n \\
\hline 15 & $\begin{array}{c}\mathbf{b} \\
(\approx 131)\end{array}$ & $\begin{array}{l}8545 \\
3845 \\
\end{array}$ & Cer & guerichi & $\begin{array}{l}\text { G. Paradiversograptus runcinatus*, Spirograptus } \\
\text { guerich } i^{* *}\end{array}$ & $\begin{array}{c}\mathrm{TS}, 7 \\
10 \\
\end{array}$ & $\begin{array}{l}\text { FADs in area; new Cer type loc; } \\
\text { *specimen of (7) lost; **see Fig.13 }\end{array}$ \\
\hline 15 & c & $\begin{array}{l}8560 \\
3801\end{array}$ & Cer & guerichi & A. encantador [MPA 51448] & 15 & $\begin{array}{l}\text { FAD in Llandovery area; earlier than } \\
\text { previously cited (22); see Fig. } 15 \mathrm{a}\end{array}$ \\
\hline
\end{tabular}

Figure A3. Details for key Llandovery area fossil localities [10c] to [15c]. 